\title{
Geochemical characterization and petrogenesis of intermediate to silicic rocks in ophiolites: A global synthesis
}

\author{
Harald Furnes $^{\mathrm{a}, *}$, Yildirim Dilek $^{\mathrm{b}}$
}




\section{ABSTRACT}

We present a global synthesis of the geochemistry of intermediate to silicic intrusive and volcanic rocks from 149 Phanerozoic to Archean ophiolites, and evaluate models for their genesis during the development of oceanic crust in different tectonic environments. Our synthesis shows that the evolved rocks in subduction-unrelated, Rift/Continental Margin ophiolites are predominantly basaltic andesite and andesite, whereas MOR type (mid-ocean ridge) ophiolites exhibit nearly equal proportions of basaltic andesite/andesite and rhyodacite and Plume/MOR type ophiolites are characterized by rhyolites. Intermediate to silicic volcanic units in the Backarc sub-group of subduction-related ophiolites are characterized by similar amounts of basaltic andesite/andesite and rhyodacite, whereas in the Backarc to Forearc, Forearc, and Volcanic Arc sub-groups they are mainly basaltic andesite/andesite. The $\mathrm{Zr}, \mathrm{Nb}$ and $\mathrm{La}$ contents of the intermediate to silicic rocks in subduction-related ophiolites are significantly lower than those of their counterparts in subduction-unrelated ophiolites. Intermediate to silicic rocks in Rift/Continental Margin and Plume/MOR type ophiolites are generally LREE-enriched, whereas those in the MOR type vary from LREE-depleted to LREE-enriched. The Backarc and Backarc to Forearc types are similar to the MOR type; silicic rocks of the Forearc and Volcanic Arc types are generally LREE-enriched. $\mathrm{Nb}, \mathrm{Sr}, \mathrm{Eu}$, and Ti exhibit negative anomalies of varying magnitudes in multi-element diagrams. Our modeling based on the $\mathrm{La}-\mathrm{SiO}_{2}$ proxies of Brophy (2009) suggests that the main process in the formation of the majority of the intermediate to silicic rocks in both subduction-unrelated and subduction-related ophiolites is partial melting of basaltic and/or gabbroic rocks beneath the spreading centers, whereas a minor volume in subduction-related ophiolites are adakites that resulted from partial melting of the subducting slab. Silicic to intermediate rocks in Plume/MOR type ophiolites appear to be generated by fractional crystallization of basaltic melt. The incompatible, non-conservative elements, such as $\mathrm{Ba}$ and $\mathrm{Th}$, are weakly to strongly enriched in subduction-related ophiolites as a result of shallow to deep enrichment associated with subduction zone processes.

Key words: Archean to Phanerozoic ophiolites, greenstone belts, intermediate to silicic volcanic rocks, plagiogranite, geochemistry, petrogenesis of ophiolites 


\section{Introduction}

Magmatic rocks of ophiolites are predominantly basaltic in composition, but intermediate to silicic intrusive and extrusive units are also present in subordinate amounts in most ophiolite complexes. Throughout the nearly 200 years of ophiolite research around the

111 world (Brongniart, 1821; Dilek and Newcomb, 2003; Dilek and Robinson, 2003), the

112 principal focus has been on the petrogenesis of mafic rock assemblages in these ancient 113 oceanic crustal units (e.g., Miyashiro, 1973, 1975; Dilek, 2003a; Pearce, 2003, 2008) and 114 relatively little attention has been paid to the origin of intermediate to silicic rocks. Since the 115 expansion of the ophiolite concept from mid-ocean ridge generated oceanic crust (e.g., 116 Moores and Vine, 1971; Anonymous, 1972) to subduction-unrelated and subduction-related 117 ophiolites (Dilek and Furnes, 2011, 2014), focus on the generation of the intermediate to 118 silicic rocks in the various types of ophiolites has become more pertinent.

In this paper we examine the occurrence and geochemistry of intermediate to silicic rocks 120 in different ophiolite types, and discuss their petrogenesis during the formation of ancient oceanic 121 crust in various tectonic settings. These rocks, although not in large volumes in comparison to 122 mafic-ultramafic units in ophiolites, reveal significant clues about melt evolution, magmatic 123 accretion processes, and partial melting of pre-existing oceanic crust during ophiolite evolution; 124 they also yield ample accessory minerals, such as zircon and monazite, which are widely used to 125 date the timing of oceanic crust generation. To better understand the diversity in the distribution 
and geochemical makeup of intermediate to silicic rock types in ophiolites, we have compiled their geochemistry in 156 ophiolites and Precambrian greenstone belts in a global synthesis. We first define these ophiolites by using geochemical discriminants in order to classify them in line with the new ophiolite classification criteria (Table 1; Dilek and Furnes, 2011, 2014). We then evaluate the geochemical compositions of intermediate to silicic rocks occurring in each of the ophiolite types separately in order to find out whether these leucocratic assemblages have specific geochemical identities. Following their geochemical characterization, we discuss their petrogenesis and magmatic evolution in different ophiolite types, which developed in distinct tectonic environments with varied mantle compositions, melt regimes, and fluid types. The field occurrence and the geochemical character of leucocratic rocks in ophiolites show considerable variations, providing additional constraints on the petrogenesis of ophiolites in different tectonic settings.

\section{Tectonic environment of formation and anatomy of ophiolites}

Dilek and Furnes (2011) have defined ophiolites as "suites of temporally and spatially associated ultramafic to felsic rocks evolved from separate melting episodes and processes of magmatic differentiation in particular oceanic environments". Figure 1 depicts the major tectonic settings in which subduction-unrelated and subduction-related oceanic crust undergoes its magmatic construction before emplacement into continental margins as ophiolites.

\subsection{Subduction-unrelated ophiolites}

Tectonic extension, continental rifting and rift-drift processes lead to lithospheric-scale thinning accompanied by asthenospheric upwelling and its decompression melting. The result is the development of a transition zone crust between the continental and oceanic lithospheric domains, known as Ocean - Continent Transition (OCT). OCTs represent the embryoic stage in the formation of oceanic crust and generally contain volcanic rocks directly overlying subcontinental mantle peridotites, limited gabbroic rocks and associated silicic intrusions and basaltic dikes and dike swarms (Fig. 1). An in-situ, modern OCT example is represented by the early Cretaceous Iberian rifted margin (Seyfert et al., 1997). On-land, fossil remnants of OCT lithospheric fragments constitute continental margin ophiolites (CMO; Dilek and Furnes, 2014), 
154

155

and some of the best CMOs occur in the Western Alps (Balestro et al., 2015; Festa et al., 2015), the Northern Apennines (Saccani et al., 2015, and the references therein), and the YarlungZangbo suture zone in SW Tibet (Liu et al., 2015).

With the onset of seafloor spreading after continental breakup, a mid-ocean ridge system gets established and new oceanic lithosphere develops (Fig. 1). The internal structure and the igneous stratigraphy of this mid-ocean ridge (MOR) generated oceanic lithosphere are largely dependent on the spreading rate, the melt-magma budget, and the magnitude and the rate of tectonic deformation keeping pace with seafloor spreading (Dilek et al., 1998). At fast spreading ridges, for example, the high rates of melt production creates a "hot environment" of oceanic crust generation in which a typical Penrose-type, crustal stratigraphy forms, complete with sheeted dikes and a transitional Moho (Fig. 1). Silicic intrusions commonly occur within the uppermost gabbros and at any structural level within the sheeted dike complex, in fast-spread MOR oceanic crust. At slow-spreading ridges, melt production is low and magma chambers are generally ephemeral, resulting in a "cold environment" of oceanic crust generation (Dilek et al., 1998). Tectonic extension commonly overpaces magmatic construction rates in this type of cold MOR setting and thus widespread high- to low-angle normal faulting and development of lithosphericscale detachment faults occur, significantly attenuating the newly formed oceanic crust. Attendant hydrothermal alteration causes low-temperature metamorphism of the lower and upper crustal units and serpentinization of the upper mantle peridotites. The Moho becomes an alteration front with advanced serpentinization.

Plume-type ophiolites may be part of oceanic plateaus or plume-proximal oceanic ridges (e.g., Iceland). The volcanic sequence, consisting predominantly of massive lava flows and subordinate pillow lavas constitute a thick sequence that may reach several tens of $\mathrm{km}$, crosscut by gabbroic to ultramafic intrusions (Fig. 1). Plume-type ophiolites are best represented by the Cretaceous oceanic crust exposed in the peri-Caribbean region (Kerr et al. 1998).

\subsection{Subduction-related ophiolites}

Fig. 1 shows a backarc spreading system in which suprasubduction zone (SSZ) ophiolites form as part of the upper plate of a subduction zone. In this tectonic environment backarc 
182 spreading centers may evolve as trench-proximal versus trench-distal (Dilek and Furnes, 2011).

183 Tectonic settings within subduction-accretion systems may be highly variable in terms of plate

184 kinematics, tectonic architecture, and chemical geodynamics (Doglioni et al., 2007). We

185 distinguish four main tectonic setings (Backarc, Backarc to Forearc, Forearc and Volcanic arc).

186 The backarc- and MOR-generated oceanic lithosphere may structurally look alike, but their

187 crustal and upper mantle units have different geochemical fingerprints.

188

189

190

191

192

193

194

195

196

197

198

199

200

201

202

203

204

205

206

207

208

209
Forearc oceanic crust may also be structurally and lithologically similar to that of the MOR oceanic crust, particularly in its lower sections. However, it differs from the subductionunrelated ophiolites in its upper crustal sections, by the presence of intermediate (andesitic) to silicic (dacite and rhyolite) extrusive and intrusive rocks, and with boninitic extrusive and intrusive rocks (Fig. 1; Dilek and Thy, 2009). The Backarc to Forearc oceanic crust makes up a hybrid type between the Backarc- and Forearc-generated oceanic crust.

The Volcanic Arc oceanic crust represents more than 20-30 million-years of magmatic construction in a suprasubduction zone setting (Dilek et al., 1991; Dilek and Furnes, 2011). The middle to lower crust of this type is dominated by abundant intrusions of diorite, tonalite and granodiorite (Fig. 1). The thickness of this type may, therefore, be considerably thicker than the other subduction-related ophiolite types.

\section{Field relationships of intermediate to silicic rocks in ophiolites}

Intermediate to silicic rocks occur in ophiolite complexes of all ages as intrusive bodies at different pseudostratigraphic levels and/or in lavas and pyroclastic deposits within their upper volcanic parts (Fig. 2) (see Fig. 14 of Furnes et al., 2015). Plagiogranite intrusions are common in modern oceanic crust and ophiolites, and generally occur near the boundary between the gabbroic rocks and the dike complex, but most commonly as pods and late-stage dikes within the sheeted dike complex. These plagiogranite types have been widely reported from many ophiolites around the world (e.g., Dilek and Eddy, 1992; Dilek and Thy, 1998, 2009; Robinson et al. 2008; Sarifakioglu et al., 2015; Dilek and Furnes, 2014), and from the oldest reported ophiolite in the Isua Supracrustal Belt in SW Greenland (Furnes et al., 2009). They also exist in the upper mantle units as dikes, crosscutting different peridotites (Fig. 2; Dilek et al., 1998), and have been 
210

reported from the Oman (Rollinson, 2014), Kizildag (Dilek and Delaloye, 1992), and Xigaze (Dai et al., 2013) ophiolites.

Andesitic, dacitic and rhyolitic extrusive rocks form the stratigraphically uppermost parts in some ophiolites, although they are less common than their intrusive equivalents (Fig. 2). Some of the best Phanerozoic ophiolites with intermediate to silicic volcanic rocks include the early Ordovician Karmøy Ophiolite in Western Norway (Pedersen and Hertogen, 1990), the Jurassic Pindos (Greece) and Mirdita (Albania) ophiolites, and the Cretaceous Oman Ophiolite (Dilek and Furnes, 2009). A Proterozoic example in which these extrusive rocks occur is the $1.73 \mathrm{Ga}$ Payson Ophiolite (Arizona, USA). The 3.51 Ga Iron Ore Group in India (Mukhopadhyay et al., 2012), the 3.12 Ga Whundo in W. Australia (Smithies et al., 2005), and the 2.75-2.65 Ga Wawa in Canada (Polat et al., 1999) are some of the notable Archean greenstone belts (Furnes et al., 2015), in which intermediate to silicic volcanic rocks (including adakites) occur in the uppermost sections of ophiolitic sequences.

\section{Intermediate to silicic rock types}

In the ophiolite complexes we have investigated, intrusive and extrusive rocks show a wide range in composition (Table 1). Intermediate rocks (with $\mathrm{SiO}_{2}$ between 52 and 63 wt. \%) include andesite and diorite, whereas the silicic rocks (with $\mathrm{SiO}_{2}$ more than 63 wt. \%) include dacite, trondhjemite, tonalite and granite. It should be noted that the term "trondhjemite" is not a name recognized in the IUGS systematics of igneous rocks (Le Bas and Streckeisen, 1991), but leucotonalite is. However, in the ophiolite literature, trondhjemite is a well-known and commonly used term, and hence we also adopt it in this paper. The term "plagiogranite", which was originally introduced as oceanic plagiogranite (Thayer, 1977), is commonly used in reference to trondhjemite, tonalite, quartz diorite, and even diorite (Coleman and Peterman, 1975; Koepke et al., 2007; Rollinson, 2009). Plagiogranite generally consists of quartz, plagioclase, hornblende, Fe-Ti oxide, and locally biotite (e.g., Brown et al., 1979). Figure 3 displays the feldspar variation of Anorthite (An), Albite (Ab) and Orthoclase (Or) in a ternary diagram, displaying various compositional fields of plagiogranite types from a selection of Phanerozoic ophiolites. Crustallyderived plagiogranites display a wide compositional range and straddle the fields for tonalite, trondhjemite and granite, whereas those that crystallized from mantle - derived melts (e.g. those 
239 in the Oman ophiolite) cover a much more restricted field across the tonalite/granodiorite

240 boundary (Fig. 3). Keratophyre, an altered and albitized silicic volcanic rock, has been reported 241 from two of the ophiolite complexes (no. 49. Fidalgo Island, and no. 65. Chamrousse, Table 1). 242 Plagiogranite and keratophyre are geochemically similar but represent intrusive and volcanic 243 rocks, respectively Brown et al. (1979).

244 For subduction-related and subduction-unrelated MORB-type ophiolites in the Phanerozoic orogenic belts, the most commonly reported intermediate to silicic intrusive rocks, independent of their original tectonic setting, are trondhjemite, plagiogranite and tonalite, and less commonly quartz-diorite and diorite. These rock types have been documented from 80 percent of the 104 ophiolites included in this study (Table 1). Intermediate to silicic lavas and/or pyroclastic rocks (basaltic andesite, andesite, dacite and rhyolite) are less abundant, and have been reported from only 35 percent of the 104 ophiolites. Trachyte occurs in some of the Rift/Continental Margin type, subduction-unrelated ophiolites (e.g., Kaczawa, Poland, no 62 of Table 1).

Of the 42 Precambrian ophiolites included in this study (Table 1), 83 percent displays intermediate to silicic lavas (andesite, dacite and rhyolite), whereas only 21 percent of them contain silicic intrusive rocks (plagiogranite, trondhjemite, tonalite). We have included in Fig. 3 the fields of Archean TTG (tonalite-trondhjemite-granodiorite) suites and the compositions of experimental melts. A few occurrences of adakite, an intermediate to silicic rock type characterized by high Sr, Na and Eu, and low Y and HREE (Defant and Kepezhinskas, 2001), have been documented from Precambrian ophiolites in India and Russia (Table 1).

Dacitic to rhyolitic extrusive rocks are most common in ophiolites occurring in nonorogenic tectonic settings (nos. 147-149) and in in-situ oceanic crust (nos. 150 - 156 of Table 1). Oceanic plagiogranites have been recovered as veins and dikes in the upper mantle peridotites and gabbros drilled at several oceanic core complexes along some segments of the slow-spreading Mid-Atlantic Ridge and Central Indian Ridge (Silantyev et al., 2010; 2011). Andesites and dacites are recovered from IODP drill sites along the East Pacific Rise, the Juan de Fuca Rise and the Galapagos Spreading Centre and may represent significant volumes of the uppermost in-situ oceanic crust at a local scale (Wanless et al., 2010; Erdmann et al., 2015). Significant volumes of silicic volcanic rocks have also been recovered in two of the many ODP drill holes in the 
269 submarine large igneous province of the Kerguelen Plateau in the southern Indian Ocean (Frey et 270 al., 2000).

271 A large number of terms have been used in the literature in regard to the terminology of

272 the intermediate to silicic rocks (Table 1). This is potentially confusing for some readers.

273 Therefore, we simplify the terminology in this study and use instead the rock names as shown in

274 Fig. 4A (i.e. andesite, basaltic andesite, rhyodacite, trachyandesite, trachyte, and rhyolite).

275

276

277

278

279

280

281

282

283

284

285

286

287

288

289

290

291

292

293

294

\section{Selected Phanerozoic and Precambrian ophiolites}

Phanerozoic orogenic belts that host the ophiolites examined in this study represent both collisional and accretionary types (Isozaki, 1997; Dilek, 2006; Condie, 2007; Windley et al., 2007; Cawood et al., 2009; Wilhem et al., 2011). The Caledonian-Appalachian, Hercynian, Uralian, Maghrebian-Alpine-Himalayan, and Qinling/Qilian/Kunlun orogenic belts are the best examples of the collisional orogenic type. The peri-Caribbean and Central Asian Orogenic belts, Gondwanide-Tasmanide, Andes, and Western Pacific and Cordilleran belts represent the most salient examples of the accretionary type orogenic belts. The modern Indonesian-Myanmar orogenic belt is a hybrid one with both active subduction - accretion processes and collision (e.g., Timor) at work.

The term greenstone belt has been generally used to describe these terranes consisting of spatially and temporally related, Precambrian intrusive - extrusive ultramafic, mafic to silicic rock suites that are associated with various types of metasedimentary rocks and intruded by granitoid plutons (de Wit, 2004). Whether greenstone belts contain ophiolites has been a longstanding and unresolved question. Some authors (e.g., Bickle et al., 1994; Hamilton, 1998, 2011) argue that true oceanic lithosphere is not represented in the Archean greenstone belts. Many others, however, present different lines of evidence supporting its presence in the Archean rock record (e.g., Dann, 1991; de Wit and Ashwal, 1997; Dann and Bowring, 1997; St-Onge et al., 1997; Sylvester et al., 1997; Dilek and Polat, 2008; Furnes at al., 2007, 2009, 2012a).

\subsection{Phanerozoic orogens}


In this study we have investigated the igneous pseudostratigraphy and geochemical makeup of 104 ophiolite complexes in 13 Phanerozoic orogenic belts around the world with a special focus on their intermediate to silicic rocks. A comprehensive description of these ophiolites and their classification based on their tectonic and geochemical fingerprints (Dilek and Furnes, 2011, 2014) are given in Furnes et al. (2014). Here, we present a synopsis of each orogenic belt with respect to its ophiolites (Table 1).

\subsubsection{Indonesian-Myanmar}

The Mesozoic - Cenozoic Indonesian-Myanmar orogenic belt (Hall, 2012; Fareeduddin and Dilek, 2015) has had a complex magmatic and tectonic history. It evolved largely during the closure of the Meso-Tethyan Ocean. Subduction rollback since the Eocene has resulted in the opening up back-arc basins (e.g., the Celebes, Philippine and Banda Seas) in the east, subduction - accretion events in the west (NE India and Indo-Myanmar Ranges) and an arc-continent collision in the SE (Timor - Australia). We have included two ophiolites from this orogenic belt in this synthesis (Table 1): Andaman (Andaman Sea, India) and Myitkyina (Myanmar).

\subsubsection{Maghrebian-Alpine-Himalayan}

The Maghrebian-Alpine-Himalayan orogenic belt extends from the Atlas Mountains in Morocco eastwards through the European Alps, Dinarides-Hellenides in the Balkan Peninsula, Anatolides-Taurides in the eastern Mediterranean region, Zagros and Makran belt in the Persian Gulf region, to Tibet - Himalaya in south-central Asia. The development of this belt occurred during a protracted evolution of various Tethyan seaways that overlapped in time and space (Stampfli and Hochard, 2009). We have examined a total of 36 ophiolites in this orogenic belt, representing continental margin, MOR, and SSZ types that were associated with the opening, seafloor spreading and subsequent closure stages of a series of Neotethyan branches (Dilek et al., 1999, 2008; Robertson, 2000; Manatschal and Müntener, 2009). The Tethyan ophiolites in this belt are principally of two age groups (Table 1): an older group in the western realm with ages around 170 -140 Ma and a younger group (east of the Aegean Sea) with Cretaceous (125-90 Ma) ages. 


\subsubsection{Caribbean Region}

The Mesozoic evolution of the Caribbean region is characterized by the development and tectonic accretion of a Cretaceous large igneous province (LIP). This Caribbean LIP was constructed during three main igneous episodes in the time interval of 125 - $70 \mathrm{Ma}$ (e.g., EscuderViruete et al., 2011). In this study we have compiled geochemical data from five ophiolites ranging in age from ca. $126 \mathrm{Ma}$ to $82 \mathrm{Ma}$ (Table 1).

\subsubsection{Cordilleran and Western Pacific}

The Circum-Pacific orogenic system, including the Cordilleran belt of western North America and the Western Pacific belt, encompasses Mesozoic-Cenozoic subduction-accretion complexes along the Pacific Rim, and parts of it are still tectonically active. The characteristic features of the Circum-Pacific orogenic system have resulted largely from the prolonged subduction of oceanic lithosphere from Triassic time onwards along the active continental margins and island arc systems fringing the North and South American, and Asian continents (e.g., Godfrey and Dilek, 2000; Dickinson, 2004). Early models for the North American Cordillera invoke a Jurassic-Cretaceous eastward-dipping subduction zone, with oceanic crust being subducted underneath the continental margin (e.g., Saleeby, 1983; Harper and Wright, 1984), whereas more recent interpretations envision a series of fringing Triassic-Jurassic island arc systems and back-arc basins with opposing subduction polarities off the coast of North America that collapsed into the continental margin through arc-trench collisions in the latest Jurassic (e.g., Dilek et al., 1991; Ingersoll, 2000; Hildebrand, 2013). In Japan, the subduction history has been shown to go back to ca. $500 \mathrm{Ma}$ (Isozaki et al., 2010). We have included 18 ophiolite complexes from this vast, peri-Pacific orogenic system in this study (Table 1).

\subsubsection{Hercynian/Variscan}

The Hercynian (or Variscan) orogenic belt (e.g. Zwart, 1967) extends from Western Iberia to Anatolia in the eastern Mediterranean region (see Fig. 1 of Furnes et al. 2014), and represents a complex subduction-accretion-collision belt. It developed during the closure of a series of Paleozoic ocean basins during the Ordovician through early Carboniferous as a result of the 
349 convergence of the supercontinents of Gondwana and Laurussia (e.g., Matte, 1991; Kroner and

350 Romer, 2013). Four ophiolite complexes from this Paleozoic orogenic system are included in this

351 study (Table 1), i.e. Kaczawa (Poland), Beja-Acebuches and Morais (Portugal), and Chamrousse 352 (France).

\subsubsection{Uralian}

The Uralides represent an arc-continent collision orogenic belt (e.g., Brown and Spadea, 1999; Ryazantsev et al., 2008) that extends from the Kara Sea in the north to Kazakhstan in the south. The remnants of early Paleozoic subduction-accretion complexes occur along a suture zone between the East European platform and the west Siberian craton (Spadea and D'Antonio, 2006; Puchkov, 2009). In this study we have included two of the Uralian ophiolites, i.e., the Nurali and Magnitogorsk (Table 1).

\subsubsection{Central Asian}

The Central Asian orogenic belt, situated between the Siberian and North China Cratons (Tarim and Sino-Korean Cratons), developed by the accretion of island arcs, ophiolites and continental blocks along the bounding cratons during the evolution of the palæo-Asian Ocean from the late Mesoproterozoic through the Mesozoic (Kröner et al., 2008; Jian et al., 2010b; Wakita et al., 2013; Zheng et al., 2013). We have included 11 ophiolite complexes in our synthesis, mostly from China with several from Mongolia (Table 1).

\subsubsection{Qingling-Qilian-Kunlun}

The Qingling-Qilian-Kunlun fold belt, also known as the Central China orogenic belt, extends in a NW-SE direction between the North China and Tarim Cratons to the North and the Yangtze Craton to the southeast (e.g., Dong et al., 2011; Song et al., 2013; Li et al., 2015). This orogenic belt developed when a series of ocean basins closed during the Paleozoic-Mesozoic,

7 following the Late Proterozoic break-up of Rodinia. Four ophiolites from this belt are included 73 here (Table 1). 


\subsubsection{Bangong-Nujian Suture}

The E-W-trending Bangong-Nujiang Suture Zone occurs between the southern Lhasa and the northern Qingtang blocks in central Tibet, and includes discontinuous exposures of Paleozoic mélange and ophiolites (Jian et al., 2009). We have examined five ophiolites from this suture zone (Table 1).

\subsubsection{Andean}

The Andean belt is the longest active orogenic system and is divided into Northern, Central, and Southern segments. Its tectonic evolution involved nearly $600 \mathrm{Ma}$ of oceanic subduction along the western continental margin of South America, beginning shortly after the break-up of Rodinia in the late Proterozoic (Oncken et al., 2006; Ramos, 2009). The Andean ophiolites (Table 1) included in this study are the Sarmiento ophiolite (Chile) and the Famatinian magmatic arc (Argentina).

\subsubsection{Appalachian}

The evolution of the Appalachian composite orogenic belt involved discrete episodes of arc - continent and continent-continent collisions during the Paleozoic. Although it differs in some respects from the Scandinavian Caledonides (e.g., van Staal et al., 2009; Zagorevski and van Staal, 2011), the timing of oceanic crust and island arc construction during the development of the Appalachians was almost the same as in Ireland (e.g. Hollis et al., 2013), Scotland (Sawaki et al., 2010), and Scandinavia (e.g., Dunning and Pedersen, 1988; and Fig. 13B of Pedersen and Hertogen, 1990). Nine representative ophiolites from this orogenic belt are included in this study (Table 1).

\subsection{Caledonides}

The tectonic history of the Scandinavian Caledonides (e.g., Roberts et al., 2007; Gee et al., 2008; Andersen et al., 2012; Hollocher et al., 2012) lasted for about 200 million years (Gee et al., 2008), starting around $600 \mathrm{Ma}$ with continental rifting and rift-drift, seafloor spreading tectonics 
399 between Baltica and Rodinia. The main oceanic crust-building episodes occurred between 500 $400470 \mathrm{Ma}$, and later between 445 - $435 \mathrm{Ma}$ (Dunning and Pedersen, 1988; Pedersen et al., 1991; 401 Dilek et al., 1997; Furnes et al., 2012b). Five ophiolite complexes from this orogenic belt are 402 included in this study (Table 1).

403

404

405

406

407

408

409

\subsubsection{Tasmanides}

The Tasmanides occupy approximately one third of the eastern Australian continent and include a collage of mountain belts that formed during a period of nearly 500 million years. The break-up of the Rodinia supercontinent between 750-525 Ma was followed by ca. 300 million years of mainly convergent-margin tectonics and magmatic activity (e.g., Spaggiari et al., 2003; Glen, 2005). We have included the $530 \mathrm{Ma}$ Weraerai terrane of the Tasmanides in this study (Table 1).

\subsection{Precambrian Complexes}

In this paper we present geochemical data from 10 greenstone belts and 42 complexes that we regard as ophiolitic in origin (Furnes et al., 2015), encompassing a time-span of nearly 3000 million years of Earth history. For detailed information the reader is referred to the comprehensive descriptions of these complexes, including regional geological maps and relevant references, presented in Furnes et al. (2015). Below we give a brief account of mafic-ultramafic complexes investigated in each of the ten greenstone belts (see also Table 1). When referring to the subdivisions of the Archean and Proterozoic eons, we have used the boundaries of Walker et al. (2013): Hadean (> 4.0 Ga); Eoarchean (4.0 - 3.6 Ga); Paleoarchean (3.6 - 3.2 Ga); Mesoarchean (3.2 - 2.8 Ga); and Neoarchean (2.8 - 2.5 Ga); Paleoproterozoic (2.5 - 1.6 Ga); Mesoproterozoic (1.6 - 1.0 Ga), and Neoproterozoic (1.0 - $0.541 \mathrm{Ga})$.

\subsubsection{Cadomian}

The Cadomian orogeny developed along the northern margin of the Gondwana supercontinent during the late Neoproterozoic (650-550 Ma) and involved the development of back-arc basin and volcanic arc ophiolites (e.g., Rossetti et al., 2015; Linnemann et al., 2008). Only one 
425 Cadomian ophiolite, the Frolosh/Struma complex in Bulgaria (Kounov et al., 2012) is included in

426 this study (Table 1).

427

428

429

430

431

432

433

434

435

436

437

438

439

440

441

442

443

444

445

446

447

448

\subsubsection{Arabian-Nubian Shield}

The Arabian-Nubian Shield comprises several, ENE-WSW-trending Neoproterozoic greenstone belts (Dilek and Ahmed, 2003; Yibas et al., 2003; Abd El-Rahman et al., 2009a) with ages of $0.6 \mathrm{Ga}-0.8 \mathrm{Ga}$ (Farahat, 2010). Six of these greenstone belts are examined in this study (Table 1 and Fig. 11 of Furnes et al., 2015), two from the Arabian Shield and four from the Egyptian Nubian Shield.

\subsubsection{India}

We have examined five greenstone belts from the Indian Craton (Table 1). Apart from the Neoproterozoic Manamedu greenstone belt, the other four are of Archean age. The Paleoarchean (3510 Ma) Iron Ore Group is among the oldest greenstone belts in the world, and is dominated by basaltic and komatiitic rock units (Mukhopadhyay et al., 2012) (see Fig. 12 of Furnes et al., 2015). The Manamedu greenstone sequence includes basaltic lavas, sheeted dikes, gabbros, and peridotites (Yellappa et al., 2010), forming a typical Penrose-type ophiolite (Dilek, 2003a).

\subsubsection{Baltica and Siberia}

We have investigated eight greenstone belts from Baltica and Siberia (Table 1), two from Finland: the Paleoproterozoic (Jormua) and Neoarchean (Suomussalmi) ophiolites (Heilimo et al., 2010). The Russian greenstone belts (Skruf'in and Theart, 2005) we have examined include Neoproterozoic (Enganepe), Paleoproterozoic (Pilgujärvi, Kholodnikan, Avarench), and Neoarchean (Tikshozero, Khizovaara) examples (see Figs. 5 and 6 of Furnes et al., 2015).

\subsubsection{Australia}

We have examined five greenstone occurrences in Australia with ages ranging from Neoarchean (Gindalbie and Kurnalpi, Meekatharra-Cue), to Mesoarchean (the Whunda Group) 
449 and Paleoarchean (the Kelly and Warrawoona Groups of the Pilbara Supergroup) (Table 1, and

450 Fig. 13 of Furnes et al., 2015). The Pilbara Craton is one of the hotly disputed cases with disparate 451 views concerning the origin of its Paleoarchean greenstone belts (Van Kranendonk and Pirajno, 452 2004; Van Kranendonk et al., 2007).

\subsubsection{China}

We have included in this study two Neoproterozoic ophiolite complexes from Chinese greenstone belts in China (Table 1, and see Fig. 7 of Furnes et al. (2015) and references therein). These are the Anhui and Jiangxi ophiolites in the Cathaysia Block (Zhou, 1989; Li et al., 1997) and the Miowan ophiolite in the Yangtze Block (Peng et al., 2012) of the South China Craton.

\subsubsection{North America}

Six greenstone belts from the North American continent have been included in this study. The youngest of these greenstone belts is the Proterozoic (0.76 Ga) Burin Group (Murphy et al., 2008) in the Avalon Zone of the southeast Newfoundland Appalachians (Table 1, and Fig. 3 in Furnes et al., 2015). The Paleoproterozoic (1.73 Ga) Payson ophiolite (Table 1) within the Mazatzal block in Arizona (USA) contains all of the mafic volcanic and plutonic components of a Penrose-type ophiolite (Dann, 1992, 1997; Dann and Bowring, 1997). The other four examples, all in the Canadian Shield (Elu Link, Abitibi, Yellowknife, Wawa) are of Neoarchean age (e.g., Cousens, 2000; Polat et al., 1999; Polat and Kerrich, 2000; Dostal and Mueller, 2013; Mvondo et al., 2013).

\subsubsection{South America}

We have examined two South American greenstone belts (Table 1). The oldest (Rio das Velhas) is Neoarchean (2.77 Ga in age), whereas the Mazaruni and Barama are Paleoproterozoic (2.25 Ga in age) and belong to the Amazonian and Sao Francisco Cratons, respectively (Cordani et al. 2009) (see also Fig. 9 of Furnes et al., 2015).

\subsubsection{Greenland}


The Precambrian rocks of southwest Greenland constitute several greenstone belts ranging in age from ca. 3.0 to $3.8 \mathrm{Ga}$ (Henriksen et al., 2009). The oldest of these is in the 3.7-3.8 Ga Isua supracrustal belt (Nutman et al., 1997), which includes an ophiolite (Isua ophiolite) containing plagiogranite pods within its sheeted dike complex (Furnes et al., 2007, 2009). We have included the Isua ophiolite in this study (Table 1).

\subsubsection{Africa}

We have examined six of the many greenstone belts existing in the African continent (Table 1, and for location, see Fig. 10 of Furnes et al., 2015). Three of these, the Leerkrans Formation, Bas Draa, and the Chewore sequences, are all of Mesoproterozoic age (Johnson and Oliver, 2000; Bailie et al., 2011; El Bahat et al., 2013). The Birimian terrane (e.g., Vidal and Alric, 1994) in the southern part of the West African Shield is of Paleoproterozoic age, and the remaining two, i.e., the Belingwe (Zimbabwe) and the Noisy Complex of the Barberton Greenstone Belt (South Africa), are of Mesoarchean and Paleoarchean ages, respectively.

\subsection{Non-orogenic Complexes}

We have included three young ophiolite complexes that are not related to orogenesis, i.e. Taitao (Chile), Tihama Asir (Red Sea, Arabia), and Iceland (Table 1). The ca. 6 Ma Taitao ophiolite formed by seafloor spreading at the Chile Ridge and was accreted into the fore-arc region of the South American Plate due to ridge-trench interaction (Veloso et al., 2005, 2009; Dilek and Furnes, 2014; Shin et al., 2015). The 22 Ma Tihama Asir complex is an in-situ continental margin ophiolite, formed during the initial stages of rifting between the African and Arabian plates in the Miocene (Dilek et al., 2009). It thus forms a typical OCT crust and transitions into the young oceanic lithosphere of the Red Sea to the west. The island of Iceland has a unique geological history in that its oceanic rocks record a complex plume/mid-ocean-ridge evolution of more than 16 million-years (Foulger, 2006). Intermediate and silicic extrusive and intrusive rocks are significant components (up to 10\%) of the in-situ oceanic crust in Iceland (Walker, 1966; Saemundsson, 1979; Carreteur et al. 2013). The deeper parts of the Icelandic upper crust include dike swarms comparable to the sheeted dike complex in the Troodos (Cyprus) ophiolite (Walker, 1975). As Iceland is part of the Mid-Atlantic spreading system and located 
502 above a hotspot (or plume), we regard its crustal units as part of an in-situ, plume-proximal MOR

503 oceanic lithosphere (Table 1; Furnes et al., 2014).

504

505

506

507

508

509

510

511

512

513

514

515

516

517

518

519

520

521

522

523

524

525

526

527

528

529

\subsection{In-situ oceanic crust}

We have also included seven examples of in-situ oceanic crust in this study (Table 1) that range in age from recent to about 48 million years. These examples represent different tectonic environments of oceanic crust formation, including mid-ocean ridges, fore-arcs and back-arcs.

\section{Element mobility}

In this study we have used the major oxides $\mathrm{SiO}_{2}, \mathrm{TiO}_{2}, \mathrm{Al}_{2} \mathrm{O}_{3}, \mathrm{FeO}^{\mathrm{t}}, \mathrm{MgO}, \mathrm{CaO}, \mathrm{Na}_{2} \mathrm{O}$ and $\mathrm{K}_{2} \mathrm{O}$, the incompatible trace elements $\mathrm{Sr}, \mathrm{Y}, \mathrm{Zr}, \mathrm{Nb}, \mathrm{V}, \mathrm{Ba}, \mathrm{Th}$, and the rare earth elements (REE) in order to discriminate between different types of ophiolites (on the basis of the compositions of their basaltic rocks), and characterize the intermediate to silicic rock assemblages in them. The behaviour of major and trace elements during low-temperature alteration and low to medium grade metamorphism of oceanic rocks (mainly mafic rocks), has been evaluated previously in several other studies. The element mobility is a highly complicated process, but is in general affected and controlled by factors such as the composition and stability of the mineral phases in unaltered protoliths and in the alteration products. The compositions, temperatures and volumes of fluid phases circulating through the lithospheric system also play a major role in element mobility. Some of the major elements, in particular $\mathrm{Ca}, \mathrm{Na}$ and $\mathrm{K}$, have been reported (e.g., Masters and Ague, 2005) to be rather mobile during metamorphism, with fluid-driven gain of $\mathrm{Na}$ and $\mathrm{Ca}$ (and $\mathrm{Sr}$ ), and loss of $\mathrm{K}$ (and $\mathrm{Rb}$ and $\mathrm{Ba}$ ). However, a recent study by Ghatak et al. (2011) of mafic-ultramafic rock units that were affected by subduction-metamorphism (from unmetamorphosed to prehnite-pumpellyite to eclogite to amphibolite/garnet amphibolite) has demonstrated no systematic variations with increasing metamorphic grades. These authors have concluded that the most likely variability in $\mathrm{Na}_{2} \mathrm{O}$ and $\mathrm{K}_{2} \mathrm{O}$ contents reflects variations in the protolith compositions rather than their mobilization during subduction metamorphism. The general consensus is that $\mathrm{Ti}, \mathrm{Al}, \mathrm{V}, \mathrm{Y}, \mathrm{Zr}, \mathrm{Nb}, \mathrm{REE}$ (particularly HREE) and Th are relatively immobile (e.g., Scott and Hajash, 1976; Staudigel and Hart, 1983; Seyfried et al., 1988; Komiya et al., 2004; Hofmann and Wilson, 2007; Dilek et al., 2008; Furnes et al., 2012a). Seven of these 
elements ( $\mathrm{Ti}, \mathrm{V}, \mathrm{Zr}, \mathrm{Y}, \mathrm{Nb}$, Th and $\mathrm{Yb}$ ) have been employed for various discrimination diagrams in order to differentiate the ophiolite types, and are therefore crucial in this connection. The elements of $\mathrm{Ba}$ and $\mathrm{Sr}$, used in the petrogenetic discussion below, are generally regarded as rather mobile. However, in our study they show patterns comparable with those of the immobile incompatible elements (e.g. Figs. 7 and 8). We hence regard them as useful in our characterization of the intermediate to felsic rocks in ophiolites (as discussed below).

\section{Geochemical classification of ophiolitic basalts}

In addition to distinguishing ophiolites based on their geological characteristics and tectonic environment of their igneous development (Fig. 1), we can evaluate the geochemical fingerprints of their mafic lavas and dikes in order to classify them thoroughly. In the geochemical classification of ophiolitic basalts we have used combinations of seven relatively immobile elements ( $\mathrm{Ti}, \mathrm{V}, \mathrm{Zr}, \mathrm{Y}, \mathrm{Nb}, \mathrm{Yb}, \mathrm{Th})$ in four discrimination diagrams $(\mathrm{Zr} / \mathrm{Ti}-\mathrm{Nb} / \mathrm{Yb}$, $\mathrm{Th} / \mathrm{Yb}-\mathrm{Nb} / \mathrm{Yb}, \mathrm{V}-\mathrm{Ti} / 1000$, and $\mathrm{TiO}_{2} / \mathrm{Yb}-\mathrm{Nb} / \mathrm{Yb}$ ). This classification involves four steps (Fig. 4A-D), following the method of Pearce (2014). As the first step, we have used the $\mathrm{Zr} / \mathrm{Ti}-\mathrm{Nb} / \mathrm{Y}$ diagram of Floyd and Winchester (1975) in order to select only the data from rocks with basaltic compositions. The second step employs the $\mathrm{Th} / \mathrm{Yb}-\mathrm{Nb} / \mathrm{Yb}$ diagram of Pearce (2008) to discriminate subduction-related versus subduction-unrelated basalts. All basalts that plot within the OIB-MORB array (also known as the mantle array) have been considered as unrelated to subduction, whereas those plotting above it are interpreted to be influenced by subduction processes. The subduction-related basalts encompass oceanic and continental arc types, or plot within the area between the mantle array and the arc type fields. Step 3 involves further discrimination of basaltic rocks using the V/Ti ratio as a proxy for supra-subduction zone (SSZ) derivation (Shervais, 1982). The modified V-Ti diagram (Pearce, 2014) discriminates between boninite, island-arc tholeiite (IAT), and MORB fields, the latter representing the tectonic environment most distant from a trench and the associated slab of subducting oceanic lithosphere. Basalts that plot within the OIB-MORB array have been further analyzed in the $\mathrm{TiO}_{2} / \mathrm{Yb}-\mathrm{Nb} / \mathrm{Yb}$ diagram (Step 4), as the $\mathrm{TiO}_{2} / \mathrm{Yb}$ ratio is a good indicator of the depth of mantle melting.

Ophiolitic basalts are first divided, following this classification procedure, as well as characteristic geological features, into two main groups: subduction-unrelated and subduction- 
related (Dilek and Furnes, 2011, 2014). The subduction-unrelated group can be further discriminated into Rift/Continental Margin, MOR, and Plume/MOR types, a subdivision that is defined by their grouping in the $\mathrm{TiO}_{2} / \mathrm{Yb}-\mathrm{Nb} / \mathrm{Yb}$ diagram. MOR type basalts plot within the MORB array while plume-related basalts plot within the OIB array and the Rift/Continental Margin types fall into the alkaline field of the OIB array (Fig. 4). The subduction-related basalts are subdivided into back-arc, back-arc to fore-arc, fore-arc, and volcanic arc types. The back-arc, back-arc to fore-arc and fore-arc types are distinguished when the majority of their compositions plot in the oceanic arc field of the $\mathrm{Th} / \mathrm{Yb}-\mathrm{Nb} / \mathrm{Yb}$ diagram and in the MORB, MORB-IAT-boninite and boninite fields in the V-Ti diagram. For the volcanic arc basalts the data plot mainly in the continental arc field of the $\mathrm{Th} / \mathrm{Yb}-\mathrm{Nb} / \mathrm{Yb}$ diagram and within the IAT and boninite fields in the V-Ti diagram. A systematic classification of the majority of the ophiolites listed in Table 1 is provided in Furnes et al. $(2014,2015)$.

Table 2 presents a geochemical summary of 168 ophiolites based on the compilation of Furnes et al. (2014, 2015), encompassing 89 Phanerozoic, 41 Proterozoic, and 40 Archean examples. These ophiolites are divided into seven types (three types of subduction-unrelated, and 4 types of subduction-related). The various proxies used to define these different ophiolite types show a wide range and a large overlap between the various types. The most useful values are the averages (shown in bold in Table 2). The subduction-unrelated ophiolite class mostly exhibits zero subduction influence (the $\mathrm{Th} / \mathrm{Yb}$-proxy), although several Phanerozoic ophiolites reflect possible subduction fingerprint. In such cases, the ophiolites are mostly of the MORB-type (see V-Ti proxy for SSZ melting). The Rift/Continental Margin and Plume type ophiolites mostly reflect formation by shallow melting E-MORB to deep melting tholeiitic to alkaline basalt (in the $\mathrm{Ti} / \mathrm{Yb}$ proxy for plume melting), whereas the MORB type indicates formation dominantly of shallow melting N-MORB.

The vast majority of ophiolites fall into the category of subduction-related types. Subduction influence in the global ophiolite record seems to increase with age into the deep time (73\% Phanerozoic, 83\% Proterozoic, and 95\% Archean). In general, the Backarc Type exhibits the least degree of subduction influence (average around 50\%), whereas the Backarc to Forearc, Forearc and Forearc/Volcanic Arc Types displays considerably higher values of subduction influence (around 70-90\%). As defined by the V-Ti proxy, the Phanerozoic and Proterozoic 
Backarc Type ophiolites mostly plot in the MORB field, whereas the Archean examples mostly have an island arc tholeiitic (IAT) character. The Forearc Type (all ages) falls mostly in the boninite (Bon) and IAT fields, whereas the Backarc to Forearc Type shows values intermediate between the Backarc and Forearc Types. The Volcanic Arc Type is defined predominantly by IAT and MORB in the V-Ti proxy (Table 2). The majority of the subduction-related ophiolite types are the products of shallow melting, similar to the subduction-unrelated ones.

All the ophiolites presented in Table 1 have been classified according to the geochemical signatures of their basalts employing the four steps outlined above and in Fig. 4. The intermediate (basaltic andesite, andesite and trachyandesite) and silicic (dacite, rhyodacite, rhyolite and trachyte) rocks from each of the seven types have been isolated and treated separately. In this context, we have used only the extrusive rock terms but it should be emphasized that a large component of many ophiolites is represented by intrusive rocks. Thus we apply the following names for the corresponding rocks: intermediate rocks are transitional gabbro/diorite, diorite and transitional syenite/diorite; for the silicic rocks granodiorite, transitional granite/granodiorite, granite and syenite.

In the following section, we treat first the subduction-unrelated group in the order of Rift/Continental Margin (Rift/CM), MOR, and Plume/MOR (P/MOR) types, and then the subduction-related group, starting with Backarc (BA), Backarc to Forearc (BA-FA), Forearc (FA), and Volcanic Arc (VA) types. This order follows the general evolutionary development of oceanic lithosphere in an ocean basin from its opening and widening (via sea-floor spreading) to closure stages (via intra-oceanic subduction) (Dilek et al., 2005).

\section{Geochemical classification of the intermediate to silicic igneous rocks}

We have plotted the intermediate to silicic rocks of the seven types of ophiolites in the $\mathrm{Zr} / \mathrm{Ti}-\mathrm{Nb} / \mathrm{Y}$ classification diagram (Fig. 5). For each ophiolite type, the percentage of examples that plot within the different fields of Fig. 5 have been calculated and plotted in Fig. 6. We recognize that some sampling bias may exist, and that the anticipated variations in standards among the analytical facilities in different laboratories where the compiled data have been produced may have certain effects on our synthesis here. However, we think that our systematic 
617 approach to fingerprinting and classifying intermediate to silicic rock units in ophiolites provide a realistic, first-order geochemical characterization of their petrogenesis.

The intermediate and silicic rocks in the Rift/CM type ophiolites are predominantly basaltic andesite and andesite (67\%), although trachytes and rhyodacites also occur in significant and similar proportions (14\% for both). The Kaczawa ophiolite (no. 62 in Table 1) is a representative example of the Rift/CM type among the ophiolites we have evaluated in this study. Basaltic andesite, andesite and rhyodacite occur in comparable proportions (49\% and 41\%, respectively) among MOR-type ophiolites; trachyandesite and trachyte are the minor components. The Corsica ophiolite (no. 6 of Table 1) is a representative example of MOR-type ophiolites (Saccani et al., 2008). The predominant, evolved rock types for the P/MOR type are rhyolite $(67 \%)$ followed by trachyte (22\%). Basaltic andesite/andesite, rhyodacite and trachyandesite $(8,6$, $6 \%$, respectively) make up only minor proportions in this ophiolite type. The most representative occurrence of the P/MOR type is Iceland (no. 149 of Table 1). We emphasize that there are significant geochemical differences between tholeiitic andesite (icelandite) and orogenic andesite, specifically demonstrated by higher $\mathrm{TiO}_{2}$ and $\mathrm{FeO}^{\mathrm{t}}$, and lower $\mathrm{Al}_{2} \mathrm{O}_{3}$ and $\mathrm{K}_{2} \mathrm{O}$ contents in the former (e.g., Jakobsson et al., 2008; Ridley, 2012).

The subduction-related BA type of ophiolite is characterized by approximately equal proportions of basaltic andesite and andesite, and rhyodacite (45 and 41\%, respectively), accompanied by $9 \%$ trachyandesite and minor proportions of trachyte and rhyolite (4 and 1\%, respectively) (Fig. 6B). The Troodos ophiolite is a representative example of the BA type (no. 16 of Table 1). The BA-FA, FA, and VA types all show similar proportions of basaltic andesite and andesite as the predominant composition (72, 73 and $74 \%$, respectively). The BA-FA and FA types also exhibit similar proportions of rhyodacite (21 and $22 \%$, respectively), minor proportions of trachyandesite (4.5 and 5\%, respectively), and insignificant proportions of trachyte and rhyolite. Rhyodacite and trachyte occur in similar proportions (12\%), with insignificant proportions of trachyte (2\%), in the VA type ophiolites. The Mirdita, Betts Cove and Yakuno ophiolites (nos. 11, 97, 54 of Table 1) are good examples of BA-FA, FA, and VA, respectively.

\subsection{Harker diagrams}


645

646

647

648

649

650

651

652

653

654

655

656

657

658

659

660

661

662

663

664

665

666

667

668

669

670

671

672

In order to provide an overview of the compositional variations among the examples from the subduction-unrelated and subduction-related ophiolites, we have plotted a series of Harker diagrams (Figs. 7 and 8). The data for the mafic rocks are from Furnes et al. (2014, 2015 and references therein), and include 5620 analyzed samples from a total of 228 ophiolites. Of these, 51 ophiolites are subduction-unrelated $(\mathrm{MOR}=25, \mathrm{P} / \mathrm{MOR}=16$, and $\mathrm{Rift} / \mathrm{CM}=10)$ and contribute 1257 analyses $(653,451$, and 153, respectively). The subduction-related group includes 177 ophiolites $(\mathrm{BA}=96, \mathrm{BA}-\mathrm{FA}=46, \mathrm{FA}=15$, and $\mathrm{VA}=20)$ and contributes 4363 analyses $(1797,1623$, 513, and 430, respectively).

\subsubsection{Subduction-unrelated}

The Harker diagrams for subduction-unrelated ophiolites are shown in Fig. 7. The mafic and intermediate rocks define some overlap with respect to their $\mathrm{SiO}_{2}$ contents, an artifact of the presence of boninites with high $\mathrm{SiO}_{2}$ contents. In the mafic rocks the spread of some of the major elements, particularly $\mathrm{TiO}_{2}, \mathrm{Al}_{2} \mathrm{O}_{3}, \mathrm{MgO}$ and $\mathrm{CaO}$, is higher than that observed for the intermediate to silicic rocks. This phenomenon may stem from several different factors: some of the analyzed samples may be cumulates; alteration or metamorphism may have changed the compositions of some samples; and, some of the samples with very high $\mathrm{MgO}$ values may be komatiite, boninite, or cumulates. The most likely candidate samples representing cumulates, as reflected by their anomalously high contents of $\mathrm{Al}_{2} \mathrm{O}_{3}, \mathrm{MgO}, \mathrm{Cr}$ and $\mathrm{Ni}$, have been deleted from the data base, and no longer considered in our synthesis. The major element compositions $\left(\mathrm{TiO}_{2}\right.$, $\mathrm{Al}_{2} \mathrm{O}_{3}, \mathrm{FeO}^{\mathrm{t}}, \mathrm{MgO}, \mathrm{CaO}$ and $\mathrm{Na}_{2} \mathrm{O}$ ) of the intermediate to silicic rocks, together with the mafic rocks, all define broad trends with increasing $\mathrm{SiO}_{2}$ contents. At a particular $\mathrm{SiO}_{2}$ concentration, the $\mathrm{TiO}_{2}$ variation is 1 wt.\%, for $\mathrm{K}_{2} \mathrm{O}$ about $4-5$ wt. $\%$, for $\mathrm{CaO}$ and $\mathrm{Na}_{2} \mathrm{O}$ about 5 wt. $\%$, for $\mathrm{Al}_{2} \mathrm{O}_{3}$ and $\mathrm{MgO}$ about 6wt.\%, and for $\mathrm{FeO}^{\mathrm{t}}$ about $8 \mathrm{wt} . \%$. The $\mathrm{FeO}^{\mathrm{t}}, \mathrm{MgO}$ and $\mathrm{CaO}$ contents all decrease continuously as the $\mathrm{SiO}_{2}$ values increase. The $\mathrm{Al}_{2} \mathrm{O}_{3}$ and $\mathrm{Na}_{2} \mathrm{O}$ trends show inflections (at around $65 \% \mathrm{SiO}_{2}$ ) from increasing to decreasing concentrations. In the case of trace element behavior, the Rift/CM and P/MOR ophiolites show large spreads in concentrations. The MOR type shows large variations in $\mathrm{Sr}, \mathrm{Y}$ and $\mathrm{Zr}$, and low concentrations of $\mathrm{Nb}, \mathrm{Ba}$ and $\mathrm{Th}$.

\subsubsection{Subduction-related}


Harker diagrams for subduction-related ophiolites are shown in Fig. 8. The data for all of the subgroups, i.e., BA, BA-FA, FA and VA, define large spreads in all the elements at any given $\mathrm{SiO}_{2}$ (considerably more than for the subduction-unrelated ophiolites). They define rather similar trends with increasing $\mathrm{SiO}_{2}$ contents and hence have not been distinguished in the figure. The average concentrations for each of the subgroups display similarities. For the mafic rocks the concentrations of some incompatible trace elements increase to about $50 \% \mathrm{SiO}_{2}$, and then decrease. The peak concentrations of the incompatible elements $\mathrm{Sr}, \mathrm{Ba}$ and La reach $~ 70$ wt. \% $\mathrm{SiO}_{2}$, with a marked, saddle pattern of maximum concentrations between 50 and $70 \mathrm{wt} \% \mathrm{SiO}_{2}$. The highest concentrations of $\mathrm{Y}, \mathrm{Zr}$ and $\mathrm{Nb}$ of the intermediate to silicic rocks are defined by two maxima at ca. $65 \mathrm{wt} . \%$ and ca. $75 \mathrm{wt} . \% \mathrm{SiO}_{2}$. The concentrations of $\mathrm{Zr}, \mathrm{Nb}$ and $\mathrm{La}$ in the intermediate to silicic rocks (Fig. 8) are in general considerably lower than those in the subduction-unrelated ophiolites (Fig. 7).

\subsection{Rare Earth Elements}

We present chondrite-normalized REE data from intermediate to silicic rocks from 108 ophiolites, with a total of 833 analyzed samples. Of these ophiolites the 28 are subductionunrelated $(\mathrm{Rift} / \mathrm{CM}=6, \mathrm{MOR}=19, \mathrm{P} / \mathrm{MOR}=3)$ with a total of 188 analyses, and 80 ophiolites are subduction-related $(\mathrm{BA}=39, \mathrm{BA}-\mathrm{FA}=24, \mathrm{FA}=5, \mathrm{VA}=12)$ with a total of 645 analyses. In Figs. 9 through 15 we show a selection of characteristic REE patterns for each type and from the youngest to the oldest ophiolites.

\subsubsection{Subduction-unrelated}

The REE patterns of the intermediate to silicic rocks of the Rift/CM type ophiolites, ranging in age from $450 \mathrm{Ma}$ to $2429 \mathrm{Ma}$, are shown in Fig. 9. The $(\mathrm{La} / \mathrm{Lu})_{\mathrm{N}}$ ratios of these ophiolites are all positive, with the majority ranging from 10 to 20 .

The REE patterns of the MOR-type ophiolites are shown in Fig. 10. The majority (ca. $70 \%)$ of these samples exhibit rather flat patterns. Nearly $34 \%$ of the samples have $(\mathrm{La} / \mathrm{Lu})_{\mathrm{N}}$ ratios $<1$, and $36 \%$ have $(\mathrm{La} / \mathrm{Lu})_{\mathrm{N}}$ ratios between 1 and 2 . However, the tonalities from the Aruba Lava Formation define slightly downward-convex REE patterns. Such patterns are comparable to 
700 subduction-originated rocks, but the close temporal relationships between the MOR-type basalts

701 and the tonalities make such an origin implausible (White et al., 1999).

702 The REE patterns of the P/MOR types (Fig. 11) are all LREE-enriched, with the majority 703 of them (ca. 75\%) having $(\mathrm{La} / \mathrm{Lu})_{\mathrm{N}}$ ratios between 1 and 10 (and mainly 5-10).

704

705

706

707

708

709

710

711

712

713

714

715

716

717

718

719

720

721

722

723

724

\subsubsection{Subduction-related}

The REE patterns of intermediate to silicic rocks in BA type ophiolites are shown in Fig. 12. The majority of this sub-group is characterized by relatively flat to moderately LREEenriched patterns, with ca. $60 \%$ and $25 \%$ having $(\mathrm{La} / \mathrm{Lu})_{\mathrm{N}}$ ratios between 1 and 10 (mostly 1 to 3 ), and $<1$, respectively. A few samples from the oldest complex (Elu Link, northeast Slave Craton, Canada; no.134 of Table 1) show exceptionally high $(\mathrm{La} / \mathrm{Lu})_{\mathrm{N}}$ ratios.

Intermediate to silicic rocks from the BA-FA type ophiolites (Fig. 13) show REE patterns highly similar to those from BA ophiolites. However, the former have a considerably higher proportion of REE patterns with $(\mathrm{La} / \mathrm{Lu})_{\mathrm{N}}$ ratios of 10 to 20 than the latter. As with the BA type, the majority of the oldest complexes (Hutti and Southern Iron Ore Group, India; nos. 114 and 116 of Table 1, respectively) show steep REE patterns with low HREE.

The REE patterns of intermediate to silicic rocks from the FA type ophiolites (Fig. 14) are similar to those from the BA-FA type ophiolites, but with a higher proportion of $(\mathrm{La} / \mathrm{Lu})_{\mathrm{N}}$ ratios between 1 and 10. However, there are pronounced differences between the rather flat patterns of the silicic rocks of the Izu-Bonin-Mariana samples and the saddle-shaped patterns of the samples from the Pekulney Ridge.

The REE patterns of intermediate to silicic rocks from the VA type ophiolites are shown in Fig. 15. The majority of the samples are characterized by high $(\mathrm{La} / \mathrm{Lu})_{\mathrm{N}}$ ratios. The oldest VA type ophiolite, the 3.4 Ga Noisy Complex of the Barberton Greenstone Belt (South Africa; no. 146 of Table 1$)$, displays particularly high $(\mathrm{La} / \mathrm{Lu})_{\mathrm{N}}$ ratios $(16-30)$.

\subsection{Multi-element diagrams}


We present MORB-normalized multi-element diagrams for intermediate to silicic rocks from 43 ophiolites and a total of 213 samples. Of these 43 ophiolites, 11 complexes are subduction-unrelated $(\mathrm{Rift} / \mathrm{CM}=4, \mathrm{MOR}=5, \mathrm{P} / \mathrm{MOR}=2)$ with a total of 94 analyses, 32 are subduction-related complexes $(\mathrm{BA}=15, \mathrm{BA}-\mathrm{FA}=4, \mathrm{FA}=4, \mathrm{VA}=9)$ with a total of 119 analyses. Figs. 16-19 show a selection of multi-element patterns for each type, organized according to the age of the ophiolites.

\subsubsection{Subduction-unrelated}

The multi-element patterns of intermediate to silicic rocks from Rift/CM (ranging in age from $450 \mathrm{Ma}$ to $1970 \mathrm{Ma}$ ), MOR (with ages ranging from < 1 Ma to $175 \mathrm{Ma}$ ) and P/MOR (with ages ranging from $<1$ to $21 \mathrm{Ma}$ ) ophiolites are shown in Figs. 16 and 17. The Rift/CM and P/MOR types display similar patterns, characterized by relative enrichment in the most incompatible elements ( $\mathrm{Th}, \mathrm{Nb}, \mathrm{La}$ ), pronounced negative anomalies in $\mathrm{Ti}$ and $\mathrm{Sr}$, and minor negative Eu anomalies. The MOR type ophiolites are, on the other hand, much less enriched in incompatible elements and display negative $\mathrm{Ti}, \mathrm{Sr}$ and Eu anomalies of varying sizes. Some samples show positive $\mathrm{Sr}$ anomalies. An unexpected feature is that most of the MOR samples exhibit negative $\mathrm{Nb}$ anomalies (Fig. 16).

\subsubsection{Subduction-related}

The multi-element patterns of intermediate to silicic rocks from BA (30 Ma to $2690 \mathrm{Ma}$ ), BA-FA (38 Ma to $3510 \mathrm{Ma}$ ), FA (47 Ma to $480 \mathrm{Ma}$ ), and VA (late Cambrian-Middle Ordovican to $3455 \mathrm{Ma}$ ) ophiolites are shown in Figs. 18 and 19. A common feature of the intermediate to silicic rocks in all of these ophiolite types is a pronounced negative $\mathrm{Nb}$ anomaly, though in the case of the FA type Lac Brompton ophiolite (no. 95 of Table 1) this feature is weak (Fig. 19). Ti and $\mathrm{Sr}$ display negative anomalies in the majority of the samples, although a small number of samples exhibit positive $\mathrm{Ti}$ and $\mathrm{Sr}$ anomalies. Apart from $\mathrm{Ti}, \mathrm{Sr}$ and $\mathrm{Nb}$, the MORB-normalized ratios increase towards the more incompatible elements (with Th being the most incompatible). However, some of the examples show relatively flat patterns (i.e., those from the Izu-BoninMariana and Troodos, nos. 156 and 16, respectively), whereas some others show very steep patterns (e.g. Northland and Annieopsqoutch, nos. 61 and 94, respectively). 


\subsection{Nb, Eu and Ti anomalies}

$\mathrm{The} \mathrm{Nb}, \mathrm{Eu}$ and $\mathrm{Ti}$ anomalies in the multi-element diagrams are characteristic of subduction-unrelated and subduction-related ophiolites in general (Figs. 16-19). They are mostly negative, although there are also some positive anomalies. Figs. 20-22 summarize the $\mathrm{Nb}, \mathrm{Eu}$ and $\mathrm{Ti}$ anomalies in histograms. The Nb-anomalies in these samples from subduction-unrelated ophiolites (Fig. 20A) range from strongly negative to positive, with a peak in the -50 to -40 interval. All samples from subduction-related ophiolites show highly negative anomalies in the 100 to -70 interval (Fig. 20B-E); no samples show positive anomalies. The largest negative $\mathrm{Nb}-$ anomaly in samples from BA-FA ophiolites is in the -100 to -90 interval, whereas samples from the other types (BA, FA, and VA), it is in the -90 to - 80 interval. The Eu-anomalies for the subduction-unrelated and subduction-related ophiolites are summarized in Fig. 21. The Euanomalies in samples from subduction-unrelated ophiolites display a rather uneven pattern with two slight peaks at the -60 to -50 and -30 to -20 intervals, whereas samples from the subductionrelated ophiolites show a symmetrical distribution around a peak at -20 to -10 . The Ti-anomalies for the subduction-unrelated and subduction-related ophiolites are also highly different (Fig. 22). The majority of the samples from subduction-unrelated ophiolites exhibit negative Ti-anomalies with the largest in the -100 to -80 interval, while the samples from subduction-related ophiolites show the largest negative anomalies in the -50 to -40 interval. Furthermore, the samples from subduction-related ophiolites also display a higher proportion of positive Ti anomalies than those from the subduction-related ophiolites (Fig. 22).

\section{Petrogenesis}

It is appropriate to point out at the outset that the geochemical data used in this study are compiled from numerous papers published over a considerable period of time. Thus, some uncertainties regarding the accuracy and the consistency of the geochemical data may exist, such as sampling bias, inter-laboratory analytical discrepancies, and the completeness and quality of the data. However, we are confident that our systematic approach to analyzing and synthesizing the extant geochemical data on the global ophiolite record provides an internally coherent discussion for the petrogenesis of intermediate to silicic rock units in ophiolites. 
The results of experimental and modeling studies (e.g., Spulber and Rutherford, 1983; Koepke et al., 2004; 2007; Annen et al., 2006; Grimes et al., 2013; Scaillet et al., 2016) and field studies (e.g., Gunnarson et al., 1998; Rollinson, 2009; 2014; Beier et al., 2015; Lundstrom and Glazner 2016) have shown that intermediate to silicic rocks can form through several different processes, including: (1) fractional crystallization of basaltic magma; (2) partial melting of hydrated basalt or gabbros in the roof zone of magma chambers; and (3) liquid immiscibility in evolved basalt. The major and trace element compositions of intermediate and silicic rocks in ophiolites, as illustrated in the Harker diagrams (Figs. 7 and 8), exhibit large variations at any $\mathrm{SiO}_{2}$ content, suggesting that different petrogenetic processes were involved in their production. This inference is supported by the large variations shown both in the REE patterns of the silicic rocks (Figs. 9-15) and the multi-element diagrams (Figs. 16-19). The principal origin of intermediate to silicic rocks is largely a result of fractional crystallization or partial melting (e.g., Gillis and Coogan, 2002; Koepke et al. 2004, 2007; Brophy, 2009; Rollinson, 2009; Grimes et al., 2013; Beier et al. 2015), although there is evidence that silicic magmas may also result from liquid immiscibility (e.g., Philpotts, 1982; Jakobsen et al., 2005), particularly in gabbroic complexes, such as the Skaergaard Layered Series (Veksler et al., 2007). Charlier et al. (2011) have also suggested that liquid-liquid unmixing producing Fe-rich and Si-rich liquids may contribute significantly to the "Daly Gap" along the liquid line of descent. The "Daly Gap" describes the lack of intermediate compositions such as andesites and trachyandesites in various volcanic provinces, in which only bimodal basalt-rhyolite suites are found. In our database, however, there is no indication of such a compositional gap (see Figs. 5, 7 and 8), and hence we regard the potential contribution of immiscible liquids as insignificant in this context. Hence, even though we do not exclude the presence of immiscible liquids, we do not consider this process further in this study.

In the following section, we discuss the importance of fractional crystallization and partial melting in the evolution of the intermediate to silicic rock suites in the ophiolites we have examined in this study.

\subsection{Partial melting and fractional crystallization}


Using the results of an experimental study of hydrous partial melting of cumulate gabbros (Koepke et al., 2004) and applying the extant D-values (partition coefficients) in the literature, Brophy (2009) has modeled the behavior of REEs and $\mathrm{SiO}_{2}$ during melting and fractional crystallization of mid-ocean ridge basalt and gabbro. His modeling work has shown that hydrous melting (equilibrium and fractional) can yield melts with $\mathrm{SiO}_{2}>\sim 62$ wt. \% with decreasing concentration of $\mathrm{REE}$ as $\mathrm{SiO}_{2}$ values increase. On the other hand, fractional crystallization of basaltic melt results in increasing concentrations of REE. This model, in which gabbroic parental material is used as the starting material for both partial melts and fractional crystallization, we regard as most appropriate for the generation of intermediate to silicic melts in ophiolite complexes. In the structurally lower sections of many ophiolites, cumulate as well as varitextured and isotropic gabbros are abundant (Fig. 2). We infer that the magmatic mush that produced these lower crustal rocks provided the parental material for intermediate to silicic liquids higher up in the oceanic crust. We are aware of the numerous experimental studies related to the production of silicic magmas, but wish to make it clear that in this first-order attempt to explain the production of silicic melts in ophiolites, the details of such studies are beyond the scope of the current study. We have applied the results of the modeling of Brophy (2009) in an attempt to explain the principal behavior of incompatible and compatible elements with progressive melting and fractional crystallization, using $\mathrm{La}$ and $\mathrm{SiO}_{2}$. In modeling of trace-element enrichment with increasing $\mathrm{SiO}_{2}$ we use $\mathrm{C}_{1} / \mathrm{C}_{0}$ (where $\mathrm{C}_{0}=$ original concentration of $\mathrm{La}$ in a starting liquid, and $\mathrm{C}_{1}$ $=$ concentration of $\mathrm{La}$ in the evolved liquid). The enrichment factor $\mathrm{C}_{1} / \mathrm{C}_{0}$ is dependent on relevant bulk distribution coefficients for partial melting and fractional crystallization. We have chosen to employ the following initial values $\left(\mathrm{C}_{0}\right)$ for the melting and fractional crystallization models: 2 and 10. For the melting model we have chosen batch melting, and for the fractional crystallization model, we have chosen the experimental data produced under the QFM buffer conditions (see Fig. 6 of Brophy, 2009). The enrichment factors $\left(\mathrm{C}_{1} / \mathrm{C}_{0}\right)$ as a function of increasing $\mathrm{SiO}_{2}$ are shown in Fig. 23A and B.

\subsubsection{Subduction-unrelated}

The $\mathrm{La}-\mathrm{SiO}_{2}$ relationships in the subduction-unrelated ophiolite types are shown in Fig. 23C. In the MOR type ophiolites the relationships are consistent with melting of a 
gabbroic/basaltic parent within the limits chosen for $\mathrm{C}_{0}$. The majority of the $\mathrm{La}-\mathrm{SiO}_{2}$ data for the P/MOR type oceanic crust (predominantly from Icelandic rocks) is compatible with fractional crystallization of basaltic parent melt. This inference is in agreement with the test performed on Icelandic silicic rocks by Brophy (2009). A few samples, however, are more in accord with partial melting of a gabbroic/basaltic parent, in agreement with the suggestion that some Icelandic silicic magmas are produced by partial melting of hydrothermally altered basaltic or gabbroic rocks (e.g., Gunnarson et al., 1998). Silicic rocks in the Rift/CM type ophiolites show distributions that can be explained by either partial melting or fractional crystallization.

\subsubsection{Subduction-related}

The $\mathrm{La}-\mathrm{SiO}_{2}$ relationships of intermediate to silicic rocks in the four types of subductionrelated ophiolites are shown in Fig. 24. There exists a large geochemical database for the BA and BA-FA types due to the predominance of ophiolites, which evolved in these tectonic settings (in the order of $70-80 \%$ ) as reflected in the global ophiolite record (Furnes et al., 2014, 2015).

The majority of the La concentrations in the BA type ophiolites define a dense cluster between ca. 2 - 15 ppm at all $\mathrm{SiO}_{2}$ concentrations (Fig. 24A), compatible with melting model 2 (i.e. $\mathrm{C}_{0}=2$ ). The extremely low concentration of incompatible trace elements, $\mathrm{TiO}_{2}$ and $\mathrm{K}_{2} \mathrm{O}$ in the majority of the silicic rocks (Fig. 8) is compatible with the generation of their magmas from depleted mafic sources such as gabbroic cumulates. This interpretation has been proposed as the most common origin of silicic magmas in oceanic crust and ophiolites (e.g., Koepke et al., 2007; Rollinson, 2009). However, there is a large scatter in the La concentrations and some samples have very high La values (ca. 70 ppm) consistent with fractional crystallization of basaltic parent melt. A good, modern analogue may be the silicic rocks recovered from the Manus backarc basin (no. 152 of Table 1) that were produced by closed-system fractional crystallization from a basaltic parent melt (Beier et al., 2015). Subsequent fractional crystallization of magma produced by partial melting may also take place, taking La concentrations away from the partial melt trend, as indicated by black arrows (Fig. 24A). 
The data from the BA-FA ophiolite type are very similar to those for the BA ophiolites. However, the dense cluster of the La concentrations is wider than that of the BA, between ca. 2 20 ppm (Fig. 24B).

Although the data from the FA ophiolites are limited, the majority of the La concentrations from these trench-proximal suprasubduction zone ophiolites fall along the trend for melting model 2 (Fig. 24C).

The data for the VA ophiolites are scattered, analogous to those from the BA and BA-FA types. However, a substantial amount of the data is clustered around the trends of the two melting models (Fig. 24D), suggesting a more varied genesis of the VA silicic rocks compared to the other types of ophiolites.

In Fig. 24 we have indicated the average $\mathrm{La}$ and $\mathrm{SiO}_{2}$ concentrations of intermediate to silicic rocks in Phanerozoic, Proterozoic and Archean ophiolites. In all the datasets (except for the FA for which the data is limited), the average La values for the Archean samples are higher than for those displayed by the Proterozoic and Phanerozoic samples.

Adakites make up an important group of intermediate to silicic rocks that is mainly restricted to subduction-related tectonic settings, and are characterized by particularly high $\mathrm{Sr}$ and low Y, and hence high Sr/Y ratios (e.g., Martin, 1999). In Fig. 25A-C all the data (1312 samples) (subdivided into Phanerozoic, Proterozoic and Archean) have been plotted in $\mathrm{Sr} / \mathrm{Y}-\mathrm{Y}$ diagrams, discriminating adakites from a typical, subduction-related calc-alkaline andesite-dacite-rhyolite (ADR) association. We have used the discrimination diagram of Castillo (2006), and have accepted rocks with $\mathrm{Sr} / \mathrm{Y}>37$ as adakitic. These diagrams show that in the Phanerozoic (870 samples), Proterozoic (105 samples) and Archean (337 samples) subduction-related ophiolites contain ca. 15\%, 33\% and 35\% adakites, respectively. Figure 25D-F demonstrates that the majority of the samples plot in the high- $\mathrm{SiO}_{2}$ field (Martin et al., 2005). None of the samples from the Rift/CM and P/MOR ophiolites plot in the adakite field, whereas $\sim 5 \%$ of the samples from MOR ophiolites plot in the adakite field (not shown).

Although adakites may form in different ways (e.g., Castillo, 2012), it is widely accepted that high- $\mathrm{SiO}_{2}$ adakites are mainly a result of melting of altered - hydrated basalts in a subducted slab. Low-SiO 2 adakites, on the other hand, appear to be the partial melting products of upper 
mantle peridotites, which were modified by silicic melts (Defant and Drummond, 1990; Martin et al., 2005; Yin et al., 2015). Under appropriate geothermal gradients along the Benioff zone (25$30^{\circ} \mathrm{C} / \mathrm{km}$ ), adakitic magmas can be produced at temperatures of $650-700^{\circ} \mathrm{C}$ at pressures of $8-18$ kbar (Martin, 1999). During ascent, these melts may be modified by reaction with the surrounding mantle. The high Sr can be accounted for by 20\% melting of a MOR-type basalt containing 100-200 ppm Sr (Rollinson, 1993). In addition, the high Sr indicates that plagioclase was not separated, as also indicated by the lack of negative Eu-anomalies in 20\% of the data (Fig. 21). The low Y (and HREE) contents in the same rocks (Fig. 25A-C) indicate that garnet and/or hornblende were residual phases in the source rocks (e.g., Martin, 1999).

The $\mathrm{La}-\mathrm{SiO}_{2}$ relationships of the intermediate to silicic rocks from subduction-unrelated and subduction-related ophiolites (Figs. 23 and 24) indicate that partial melting of a gabbroic or basaltic source rock was the most important petrogenetic process. However, fractional crystallization from basaltic parental melt appears to be more important for the subductionunrelated than for the subduction-related ophiolites. This is particularly the case for the P/MOR types, and to some extent for the Rift/CM ophiolites. This interpretation is supported by the histograms showing the distribution of Eu-anomalies and $\mathrm{TiO}_{2}$-depletion (Figs. 21 and 22). Both figures show a considerably higher percentage of negative values for the subduction-unrelated ophiolites than for the subduction-related ones, attesting to increased importance of fractional crystallization in the former. Indeed, nearly $27 \%$ of the subduction-related ophiolites have positive Eu-anomalies, indicating accumulation of plagioclase in the magma, compared to 18\% for the subduction-unrelated ophiolites (Fig. 21).

\subsection{Enrichment of non-conservative elements; proxies for subduction processes}

Enrichment of non-conservative elements (i.e., $\mathrm{Cs}, \mathrm{Ba}, \mathrm{Th}, \mathrm{U}, \mathrm{K}, \mathrm{La}, \mathrm{Ce}, \mathrm{Pb}, \mathrm{Sr}, \mathrm{P}, \mathrm{Nd}$ ) in the mantle wedge above subduction zones occurs when fluids and silicic melts are released from subducted, altered oceanic crust and associated sediments move into and react with upper mantle peridotites (e.g., Pearce and Parkinson, 1993; Hawkesworth et al., 1997; Elburg et al., 2002;

Pearce et al., 2005). The transport of non-conservative incompatible elements (i.e., Ba and Th, see below) in hydrous fluids differs significantly. While $\mathrm{Ba}$ is highly mobile and released over a wide range of temperatures, Th is much less mobile in a fluid phase (e.g., Hawkesworth et al., 1997). 
922 Therefore, fluids released from subducted material and their interaction with melt source regions 923 result in high $\mathrm{Ba} / \mathrm{Th}$ values in the magmas generated. Th-enrichment is enhanced, on the other 924 hand, by its incorporation into melts from subducted sediments (Plank and Langmuir, 1998). High

925 Th concentrations in silicic rocks are thus consistent with magmas that originated from sources that were enriched in Th by melts derived from subducted sediments (e.g., Plank and Langmuir, 1998; Plank, 2005).

In contrast to the non-conservative elements, conservative elements (e.g., $\mathrm{Nb}, \mathrm{Ta}, \mathrm{Zr}, \mathrm{Hf}$, Ti, HREE) are not transported in fluids, resulting in negative anomalies in MORB-normalized, multi-element diagrams (see Figs. 16-19). One of the most conspicuous conservative element negative anomalies is the "Nb-anomaly", commonly displayed by subduction-related magmatic rocks. Several models have been proposed (e.g., Kelemen et al., 2004) to explain negative Nb anomalies. A recent study of Baier et al. (2008) suggests that the main reason for Nb-depletion may be a consequence of the low solubility of $\mathrm{Nb}$ in a water-rich environment in the shallow parts of subduction zones.

In a comprehensive study, the behavior of non-conservative versus conservative elements and their ratios in the Mariana arc-basin system, Pearce et al. (2005) developed some proxies for shallow, deep, and total subduction contributions. High $\mathrm{Ba} / \mathrm{Th}$ characterizes the lowertemperature fluid component because both elements are mobilized in melts, but only $\mathrm{Ba}$ is mobilized in fluids. Hence, the $\mathrm{Ba} / \mathrm{Th}$ ratio is a proxy for shallow subduction enrichment. High $\mathrm{Th} / \mathrm{Nb}$ characterizes the high-temperature portion of a subduction zone, and thus the $\mathrm{Th} / \mathrm{Nb}$ ratio is a proxy for deep subduction enrichment. $\mathrm{The} \mathrm{Ba} / \mathrm{Nb}$ ratio is a proxy for the total subduction enrichment.

Here, we compare the distribution of these ratios, plotted against Th, for mafic and associated intermediate to silicic rocks from subduction-related ophiolites. The data are presented in Fig. 26. In all the plots in Fig. 26 there is a pronounced scatter, and at any given Th-value the elemental ratios $(\mathrm{Ba} / \mathrm{Th}, \mathrm{Th} / \mathrm{Nb}, \mathrm{Ba} / \mathrm{Nb})$ vary by 2 to 4 orders of magnitude. There is a substantial overlap between the mafic and silicic rocks, but the data for the silicic rocks are displaced to higher Th-values than for the mafic rocks. Since the bulk distribution coefficients for $\mathrm{Ba}, \mathrm{Th}, \mathrm{Nb}$ are rather similar (Pearce et al., 2005), the ratios of these elements should not change significantly during partial melting and/or fractional crystallization. Thus, the scatter in the ratios as shown in 
952 Fig. 26 can be attributed mainly to enrichment of Ba and Th during shallow and deep subduction.

953 The average values of BA and BA-FA rocks are very similar, though the Ba/Th ratio (shallow 954 subduction component) of the BA is slightly higher than that of the BA-FA. The largest shallow 955 subduction component is shown by the FA generated silicic rocks. We note, however, that the 956 amount of data is much smaller for FA ophiolites than other SSZ environments. The highest 957 average value of the deep subduction contribution ( $\mathrm{Th} / \mathrm{Nb}$ ratio) is shown by VA rocks, which 958 also show the highest Th-values.

The substantial variations in the ratios shown in Fig. 26 may be a result of a combination of several factors, including: (1) the duration of subduction, (2) subduction rate, and (3) character of the subducted material. The duration of subduction in the igneous development of an ophiolite 962 is difficult to constrain and is largely unknown. The longer the subduction lasts at a given site, the 963 higher the enrichment of non-conservative elements is in a potential melt source. The subduction 964 rate and hence the volume of crust subducted per unit time may differ significantly along 965 subduction zones, for example from about 20 to $170 \mathrm{~mm} / \mathrm{year}$ at the South Sandwich and the

966 Tonga Trenches, respectively (Plank and Langmuir, 1998). As to the third factor, the sedimentary 967 cover on the subducting oceanic crust also differs considerably both in terms of its lithology and 968 geochemistry. Lithologically, the sedimentary cover comprises siliceous ooze, chert/radiolarite,

969 clay, carbonate, silt/sand and volcaniclastic sediments. The proportions of these components may 970 vary considerably, and the variations in their compositions (e.g., Ba, Th, Sr and REE) may be 971 more than an order of magnitude (Plank and Langmuir, 1998). Furthermore, the sedimentary 972 cover on an oceanic plate with abundant detritus derived from an old continental source may 973 exhibit considerably higher concentrations of Th than those in an oceanic setting. For example, 974 the sedimentary cover on the oceanic plate subducting at the East Sunda, Java and Sumatra 975 Trenches has had a long history of sedimentation from the Australian continent, and it thus has 976 high Th (about 8-10 ppm). In contrast, the sedimentary cover on the Pacific Plate subducting at 977 the Mariana and Izu-Bonin Trenches contains around $2.5 \mathrm{ppm}$ Th. The Nb contents, on the other 978 hand, show rather minor variations (Plank and Langmuir, 1998).

\section{Summary and geodynamic models}


In order to explain the geochemical character of the intermediate to silicic rocks of the various ophiolite types, it is relevant to review the most significant aspects of the mafic rocks in the same ophiolite complexes. This is because the geochemical characteristics of the mafic rocks are inherited by the intermediate and silicic rocks, as a result, of either fractional crystallization or partial melting processes.

Fig. 27 summarizes the tectonic settings of subduction-unrelated (A), and subductionrelated (B) ophiolites, and their igneous processes. In the continuous progression from rifting to drifting (e.g., Dilek et al., 2005; Liao and Gerya, 2015) the Rift/CM ophiolites represent the initial generation of oceanic crust (Fig. 27A1), forming a rather simple magmatic and sedimentary assembly (e.g., Dilek and Furnes, 2011, 2014) compared to the MOR ophiolites, with their mature oceanic crust (Fig. 27A2). P/MOR ophiolites (Fig. 27A3) are special cases of crustal growth at plume-proximal oceanic ridges (e.g. Iceland) or near oceanic plateaus (Dilek, 2003b). The magmatic evolution of these types of oceanic crust is dominated by ultramafic to mafic intrusions and lavas of E- to N-MORB composition (e.g., Dilek and Furnes, 2011; Saccani et al. 2015), produced by decompression melting of fertile lherzolitic mantle. However, the Rift/CM, MOR and P/MOR ophiolites in this compilation all contain minor to significant volumes of intermediate to silicic rocks (Fig. 5; Table 1). Geochemically the majority of P/MOR rocks, and a subordinate part of Rift/CM rocks are high in incompatible elements (Fig. 23). Most of the intermediate to silicic rocks of the MOR ophiolites, a substantial part of the Rift/CM type, and a minor part of the P/MOR ophiolites have low to very low contents of incompatible elements (e.g., La) at all $\mathrm{SiO}_{2}$ concentrations (Fig. 23).

The tectonic settings and physical constraints of the structurally and geochemically more complex subduction-related FA, BA and BA-FA ophiolites (see Fig. 2) are shown in Fig. 27B. A fourth category, the VA ophiolites (see Fig. 2 of Dilek and Furnes, 2014), differ from these three in that they have a thicker, more arc-like crustal architecture with a well-developed middle crust (Dilek and Furnes, 2011). The crustal structure and main melting processes at the spreading centers, yielding mafic rocks of the subduction-related ophiolites, are comparable with those of the subduction-unrelated MOR ophiolites. However, processes taking place at the interface between the subducting slab and the overlying mantle result to varying extent in changes in the solidus temperature and geochemistry of the mantle. Thus, the geochemical signatures of the 
1010 basaltic magmas, and associated gabbroic rocks (isotropic and layered gabbro), generated in

1011 subduction-related environments may differ profoundly from those generated in subduction-

1012 unrelated settings. The mantle wedge above the subduction zone becomes enriched in fluid-

1013 mobilized elements (Ba and several other non-conservative elements), whereas Th can be

1014 transferred into the mantle by melts derived from subducted sediments. $\mathrm{As}_{2} \mathrm{O}$ is released from

1015 subducting metabasalt and overlying sediments, the solidus of the mantle peridotite is lowered by

1016 as much as $500-600^{\circ} \mathrm{C}$ compared to the dry solidus at depths of $75-120 \mathrm{~km}$ (Mysen and

1017 Biettcher, 1975; Grove et al., 2006), and the degree of melting increases upward and away from

1018 the subduction zone as the temperature increases (Grove et al., 2006; 2009). The Th

1019 concentrations in the mafic melts and subsequently the intermediate and silicic rocks derived from

1020 the mafic rocks may vary by two orders of magnitude (Fig. 26), controlled by several factors such

1021 as the original Th concentration in the mantle, the Th concentration in the subducted sediments

1022 (e.g. Plank and Langmuir, 1998), the volume of sediment, and the subduction rate. Furthermore,

1023 sediments may detach from the slab/mantle interface to become a sediment reservoir in the back-

1024 arc mantle (Currie et al., 2007; Gonzalez et al., 2015) and get incorporated into melts distant from

1025 the subduction zone (Fig. 27B). The basaltic and gabbroic rocks, with highly variable

1026 concentrations of non-conservative elements (e.g. Ba and Th), may in turn be the source of

1027 intermediate and silicic melts, generated at interfaces between basaltic magma chambers and the

1028 overlying upper crustal rocks.

1029

In Fig. 27C we summarize the main processes inferred as responsible for the formation of

1030 the intermediate to silicic rocks, and propose a tentative quantification of the importance of these

1031 processes in different ophiolite types. Fractional crystallization appears to have been an important

1032 process in the formation of the intermediate to silicic rocks in Rift/CM and P/MOR ophiolites in

1033 the subduction-unrelated class, as well as VA ophiolites in the subduction-related class. This

1034 inference suggests that magma chambers might have operated as closed-systems for a sufficient

1035 amount of time for fractionation and compositional zoning of the magma to take place, as

1036 illustrated in Fig. 27C1. A closed-system magma chamber operation appears to be a common

1037 phenomenon reported from numerous volcanic systems (e.g., Hildreth, 1981; Widom et al., 1992;

1038 Watanabe et al., 2006). Fractional crystallization was likely to be of subordinate importance, on

1039 the other hand, during the igneous construction of the MOR, BA, FA, and BA-FA ophiolites.

1040 Partial melting of hydrothermally altered crust was the most common process resulting in the 
1041

1042

1043

1044

1045

1046

1047

1048

1049

1050

1051

1052

1053

1054

1055

1056

1057

1058

1059

1060

1061

1062

1063

1064

1065

1066

1067

1068

1069

1070

majority of the intermediate to felsic rocks of the Rift/CM (estimated to 60\%), MOR (estimated to 95\%), and the BA, FA and BA-FA (estimated to 75\%) ophiolites, as well as a high proportion of the VA ophiolites (estimated to 40\%). This process, in which an upward-migrating melt lens impinges upon, reheats and melts the basal part of a previously crystallized magma chamber, has been proposed by several investigators for the origin of plagiogranites (e.g., Flagler and Spray, 1991; France et al., 2010; Grimes et al., 2013). Experimental partial melting of hydrothermally altered crust shows that melting starts at a temperature exceeding $850^{\circ} \mathrm{C}$ (Gillis and Coogan, 2002; France et al., 2010).

In Fig. 27C2 we illustrate a scenario whereby various, hydrothermally altered components of an ophiolite, i.e. the sheeted dike complex, isotropic gabbro, and cumulate gabbro, are in contact with a melt lens (magma front), and undergo partial melting. This scenario, in which the parental rocks range from solidified liquid (dikes) to cumulate gabbro, may result in intermediate to silicic melts with highly variable concentrations of incompatible trace elements. We show this development by numbers (1-3) in Fig. 27C2 and correspondingly in the $\mathrm{La}_{-} \mathrm{SiO}_{2}$ diagram, in which partial melts from the dikes (marked 1) acquire the highest concentration of incompatible trace elements (e.g., La), and those from the cumulates (marked 3) obtain the lowest concentration. When a melt lens solidifies (producing dikes + gabbro) and is hydrothermally altered, impingement of a younger melt lens from below may result in the production of a new generation of intermediate to silicic melts, and this process may be repeated several times. This model is consistent with field observations in ophiolites, where plagiogranite bodies crosscut plutonic gabbros and basalt dike swarms, and are in turn crosscut by younger basalt dikes (Fig. 2). Melts derived from these three different components (dikes, isotropic and cumulate gabbro) may also have a profound influence on the concentration of Th, and thus be partly responsible for the large concentration range observed in Fig. 26.

Slab-generated melts that result in intermediate to silicic rocks of adakitic character, described above and illustrated in Fig. 25, represent a relatively small fraction $(\sim 15 \%$ in Phanerozoic ophiolites) of subduction-related ophiolites (Fig. 27C3). Some adakites are very low in incompatible elements (e.g., La, see Fig. 27C3), suggesting that these melts were generated from highly-depleted MORB. It is interesting to note, however, that Precambrian ophiolites seem to contain a higher percentage of adakites (ca. 35\%). This observation indicates that physical 
1071 conditions during the Precambrian were more favorable for slab melting than during the

1072 Phanerozoic. This phenomenon may have resulted from higher geothermal gradient along 1073 relatively shallow-dipping subduction zones during the Precambrian (e.g., Yin et al., 2015; Palin 1074 and White, 2016). This inference is also consistent with the observation that the rare low-SiO 2 1075 adakites (Fig. 25D) are of Phanerozoic age, i.e. they formed within the mantle (rather than at the 1076 slab/mantle interface) at a lower geothermal gradient (e.g., Martin, 1999).

\section{Conclusions}

Geochemical characterization of intermediate to silicic rock sequences of 149 Phanerozoic to Archean ophiolites and in-situ oceanic crust at 7 sites has revealed that:

- Rift/Continental Margin and MOR ophiolites are composed mainly of basaltic andesite/andesite, and basaltic andesite/andesite and rhyodacite, respectively, whereas Plume/MOR ophiolites mainly contain rhyolite. Backarc ophiolites are characterized by similar amounts of basaltic andesite/andesite and rhyodacite, whereas the BA-FA, FA, and VA ophiolites are predominantly basaltic and andesitic in composition.

- The REE and multi-element patterns of the Rift/Continental Margin and Plume/MOR ophiolites show enrichment in the most incompatible elements ( $\mathrm{La}, \mathrm{Ce}, \mathrm{Nd}$ ), whereas the MOR ophiolites are depleted to enriched in these elements. The BA and BA-FA ophiolites are similar to the MOR type; the FA ophiolites are generally enriched, whereas VA ophiolites are generally enriched in incompatible elements.

- $\mathrm{La}-\mathrm{SiO}_{2}$ relationships suggest that the principal process behind the generation of the intermediate to silicic magmas in most of the subduction-unrelated and subduction-related ophiolites was partial melting of basaltic and/or gabbroic source rocks at the spreading centers. In P/MOR ophiolites the principal process was fractional crystallization of basaltic melt.

- Subduction-related ophiolites are weakly to strongly enriched in incompatible, nonconservative elements (i.e. Ba and Th) due to shallow- to deep-level enrichment associated with subduction zone processes. 
Financial support over many years of field work in Phanerozoic ophiolites and Precambrian greenstone belts, and numerous geochemical analyses have been supported by the Norwegian Research Council and the Meltzer Foundation at the University of Bergen (HF), and Miami University, the National Science Foundation (NSF), and the Ocean Drilling Program (ODP) (YD). Eva Bjørseth kindly helped with the preparation of some of the illustrations. We express our thanks to S. Whattam, J. Shervais, A. Ishiwatari, and F. L. Boedo for their assistance in getting access to some of the literature and the relevant geochemical data, and to B. Robins for providing us with helpful comments on an early version of the manuscript. We acknowledge the insightful and constructive reviews for the journal by two anonymous reviewers that helped us improve the paper. We thank Tim J. Horscroft (Elsevier) and Carlo Doglioni (Editor) for inviting us to contribute this paper to Earth Science Reviews.

\section{References}

Andersen, T.B., Corfu, F., Labrousse, L., Osmundsen, P-T., 2012. Evidence for hyperextension along the pre-Caledonian margin of Baltica. J. Geol. Soc., London 169, 601-612.

Annen, C., Blundy, J.D., Sparks, S.J., 2006. The genesis of intermediate and silicic magmas in deep crustal hot zones. J. Geol. 47 (3), 505-539.

Anonymous, 1972. Penrose field conference on ophiolites. Geotimes 17, 24-25.

Angiboust, S., Pettke, T., De Hoog, J.C.M., Caron, B., Oncken, O., 2014. Cannelized fluid flow and eclogite-facies metasomatism along the subduction shear zone. J. Petrol. 55 (5), 883-916; doi:10.1093/petrology/egu010.

Baier, J., Audétat, A., Keppler, H., 2008. The origin of the negative niobium tantalum anomaly in subduction zone magmas. Earth Planet. Sci. Lett. 267, 290-300.

Bailie, R., Gutzmer, J., Rajesh, H.M., 2011. Petrography, geochemistry and geochronology of the metavolcanic rocks of the Mesoproterozoic Leerkrans Formation, Wilgenhoutsdrif Group, South Africa - back-arc basin to the Areachap volcanic arc. S. Afr. J. Geol. 114 (2), 167 194. 
Balestro, G., Festa, A., Dilek, Y., and Tartarotti, P., 2015. Pre-Alpine Extensional Tectonics of a Peridotite-Localized Oceanic Core Complex in the Late Jurassic, High-Pressure Monviso ophiolite (Western Alps). Episodes 38(4), 266-282, doi: 10.18814/epiiugs/2015/v38i4/82421.

Barker, F., 1979. Trondhjemite: definition, environment and hypotheses of origin. In: Barker, F. (Ed.), Trondhjemites, Dacites and Related Rocks. Elsevier, Amsterdam, pp. 1-12.

Bebout, G.E., Penniston-Dorland, S.C., 2016. Fluid and mass transfer at subduction interfaces The field metamorphic record. Lithos 240-243, 228-258.

Beier, C., Bach, W., Turner, S., Niedermeier, D., Woodhead, J., Erzinger, J., Krumm, S., 2015. Origi of silicic magmas at spreading centres - an example from the south east rift, Manus Basin. J. Petrol. 56 (2), 255-277.

Bickle, M.J., Nesbit, E.G., Martin, A, 1994. Archean greenstone belts are not oceanic crust. J. Geol. 102, 121-128.

Brongniart, A., 1821. Sur le gisement ou position relative des ophiolites, euphotides, jaspes, etc. dans quelques parties des Apennins: Annales des Mines, Paris, 6, 177-238.

Brophy, J.G., 2009. $\mathrm{La}_{-} \mathrm{SiO}_{2}$ and $\mathrm{Yb}_{-} \mathrm{SiO}_{2}$ systematics in mid-ocean ridge magmas: implications for the origin of oceanic plagiogranite. Contrib. Mineral. Petrol. 158, 99-111.

Brown, D. and Spadea, P., 1999. Processes of forearc and accretionary complex formation during arc-continent collision in the southern Ural Mountains. Geology 27, 649-652.

Castillo, P.R., 2006. An overview of adakite petrogenesis. Chinese Sci. Bull. 51(3), 257-268.

Castillo, P.R., 2012. Adakite petrogenesis. Lithos 134-135, 304-316.

Cawood, P.A., Kröner, A., Collins, W.J., Kusky, T.M., Mooney, W.D., Windley, B.F., 2009. Accretionary orogens through Earth history. Geol. Soc., London, Spec. Publ. vol. 318, pp. $1-36$.

Charlier, B., Namur, O., Toplis, M.J., Schiano, P., Cluzel, N., Higgins, M.D., Auwera, J.V., 2011. Large-scale silicate liquid immiscibility during differentiation of tholeiitic basalt to granite and the origin of the Daly gap. Geology 39 (10), 907-910. 
1153 Charreteur, G., Tegner, C., Haase, K., 2013.Multiple ways of producing intermediate and silicic

1154

1155

1156

1157

1158

1159

1160

1161

1162

1163

1164

1165

1166

1167

1168

1169

1170

1171

1172

1173

1174

1175

1176

1177

1178 rocks within the Thingmúli and other Icelandic volcanoes. Contrib. Mineral. Petrol. 166, 471-490.

Coleman, R.G., Peterman, Z.E., 1975. Oceanic plagiogranite. J. Geophys. Res. 80 (8), 1099-1108.

Condie, K.C., 2007. Accretionary orogens in space and time. In: Hatcher, R.D., Jr., Carlson, M.P., McBride, J.H., Marinez Catalán, J.R. (Eds.), 4-D Framework of Continental Crust. Geol. Soc. Am. Mem. 200, 145-158.

Cordani, U.G., Teixeira, W., D’Agrella-Filho, M.S., Trindade, R.I., 2009. The position of the Amazonian Craton in supercontinents. Gond. Res. 15, 396-407.

Cousens, B., 2000. Geochemistry of the Archean Kam Group, Yellowknife Greenstone Belt, Slave Province, Canada. J. Geol. 108, 181-197.

Currie, C.A., Beaumont, C., Huismans, R.S., 2007. The fate of subducted sediments: A case for backarc intrusion and underplating. Geology 35 (12), 1111-1114; Doi:10.1130/G24098A.1.

Dai, J., Wang, C., Polat, A., Santosh, M., Li, Y., Ge, Y., 2013. Rapid forearc spreading between 130 and 120 Ma: Evidence from geochronology and geochemistry of the Xigaze ophiolite, southern Tibet. Lithos 172-173, 1-16.

Dann, J.C., 1991. Early Proterozoic ophiolite, central Arizona. Geology 19, 590-593.

Dann, J.C., 1992. The origin and emplacement of the Early Proterozoic Payson ophiolite, Central Arizona. PhD thesis, Washington University, 340 pp.

Dann, J.C., 1997. Pseudostratigraphy and origin of the Early Proterozoic Payson ophiolite, central Arizona. Geol. Soc. Am. Bull. 209 (3), 347-365.

Dann, J.C., Bowring, S.A., 1997. The Payson ophiolite and Yavapai-Mazatzal orogenic belt, central Arizona. In: de Wit, M.J., Ashwal, L.D. (Eds.), Greenstone Belts. Oxford University Press, Oxford, U.K, pp. 781-790.

Defant, M.J., Drummond, M.S., 1990. Derivation of some modern arc magmas by melting of young subducted lithosphere. Nature 347, 662-665. 
1179

1180

1181

1182

1183

1184

1185

1186

1187

1188

1189

1190

1191

1192

1193

1194

1195

1196

1197

1198

1199

1200

1201

1202

1203

1204

1205

1206

Defant, M.J., Kepezhinskas, P., 2001. Evidence suggests slab melting in arc magmas. Eos, Trans. Am. Geophys. Union 82 (6), 65-69.

de Wit, M.J., 2004. Archean greenstone belts do contain fragments of ophiolites. In: Kusky, T.M. (Ed.), Precambrian Ophiolites and related Rocks. Development in Precambrian Geology, vol. $13,599-614$.

de Wit, M.J., Ashwal, L.D. (Eds.), 1997. Greenstone Belts. Clarendon Press, Oxford, 809 pp.

Dickinson, W.R., 2004. Evolution of the North American Cordillera. Ann. Rev. Earth Planet. Sci. $32,13-45$.

Dilek, Y., 2003a. Ophiolite concept and its evolution: In, Dilek, Y. and Newcomb, S. (Eds.), Ophiolite Concept and the Evolution of Geological Thought, Geol. Soc. Am. Spec. Paper, vol. 373, pp.1-16.

Dilek, Y., 2003b. Ophiolites, plumes and orogeny. In, Dilek, Y. and Robinson, P.T. (Eds.), Ophiolites in Earth History, Geol. Soc., London, Spec. Publ. vol. 218, pp. 919.

Dilek, Y., 2006. Collision tectonics of the Eastern Mediterranean region: Causes and consequences. In, Dilek, Y. and Pavlides, S. (Eds.), Geol. Soc. Am. Spec. Pap. vol. 409, pp. 1-13. DOI: 10.1130/2006.2409(1).

Dilek, Y., Thy, P., Hacker, B., Grundvig, S., 1999. Structure and petrology of Tauride ophiolites and mafic dike intrusions (Turkey): Implications for the Neotethyan ocean. Geol. Soc. Am. Bull. 111, 1192-1216.

Dilek, Y. and Delaloye, M., 1992. Structure of the Kizildag ophiolite, a slow-spread Cretaceous ridge segment north of the Arabian promontory. Geology 20, 19-22.

Dilek, Y. and Eddy, C.A., 1992. The Troodos (Cyprus) and Kizildag (S. Turkey) ophiolites as structural models for slow-spreading ridge segments. J. Geol. 100, 305-322.

Dilek, Y. and Thy, P., 1998. Structure, petrology, and seafloor spreading tectonics of the Kizildag ophiolite (Turkey). In, Mills, R. and Harrison, K. (Eds.), Modern Ocean Floor Processes and the Geological Record, Geol. Soc., London, Spec. Publ. vol. 148, pp. 43-69. 
Dilek, Y., Ahmed, Z., 2003. Proterozoic ophiolites of the Arabian Shield and their significance in Precambrian tectonics. In: Dilek, Y., Robinson, P.T. (Eds.), Ophiolites in Earth History. Geol. Soc., London, Spec. Publ. vol. 218, pp. 685-700.

Dilek, Y., Newcomb, S., 2003. Ophiolite concept and the evolution of geological thought. Geol. Soc. Am. Spec. Pap. vol. 373, Boulder, Colorado, USA.

Dilek, Y. and Robinson, P.T., 2003. Ophiolites in Earth History: Introduction. In: Dilek, Y., Robinson, P.T. (Eds.), Ophiolites in Earth History. Geol. Soc., London, Spec. Publ. vol. 218, pp. 1-8.

Dilek, Y., Polat, A., 2008. Suprasubduction zone ophiolites and Archean tectonics. Geology 36 (5), 431-432.

Dilek, Y., Furnes, H., 2009. Structure and geochemistry of Tethyan ophiolites and their petrogenesis in subduction rollback systems. Lithos 113, 1-20.

Dilek, Y. and Thy, P., 2009. Island arc tholeiite to boninitic melt evolution of the Cretaceous Kizildag (Turkey) ophiolite: Model for multi-stage early arc - forearc magmatism in Tethyan subduction factories. Lithos 113 (1/2), 68-87.

Dilek, Y., Furnes, H., 2011. Ophiolite genesis and global tectonic fingerprinting of ancient oceanic lithosphere. Geol. Soc. Am. Bull.123 (3/4), 387-411.

Dilek, Y., Furnes, H., 2014. Ophiolites and their origins. Elements 10, 93-100.

Dilek, Y., Furnes, H., and Skjerlie, K.P., 1997. Propagating rift tectonics of a Caledonian marginal basin: Multi-stage seafloor spreading history of the Solund-Stavfjord ophiolite in western Norway. Tectonophysics 280 (3/4), 213-238.

Dilek, Y., Moores, E.M., and Furnes, H., 1998. Structure of modern oceanic crust and ophiolites and implications for faulting and magmatism at oceanic spreading centers. In, R. Buck, J. Karson, P. Delaney, and Y. Lagabrielle (Eds.), Faulting and Magmatism at Mid-Ocean Ridges, Am. Geophy. Union Monog. 106, 219-266. 
1232 Dilek, Y., Shallo, M., Furnes, H., 2005. Rift-Drift, Seafloor Spreading, and Subduction Tectonics of Albanian Ophiolites. Intern. Geol. Rev. 47, 147-176.

1234 1235

1236

1237

1238

1239

1240

1241

1242

1243

1244 1245

1246

1247

1248

1249

1250

1251

1252

1253

1254

1255

1256

Dilek, Y., Furnes, H., Shallo, M., 2008. Geochemistry of the Jurassic Mirdita ophiolite (Albania) and the MORB to SSZ evolution of a marginal basin oceanic crust. Lithos 100, 174-209.

Dilek, Y., Furnes, H., Schönberg, R., 2009. Structure and geochemistry of the incipient oceanic crust of the Red Sea and the rifted margin of western Arabia. Am. Geophys. Union, Fall Meeting (abstract), San Francisco.

Dilek, Y., Thy, P., Moores, E.M., 1991. Episodic dike intrusion in the northwestern Sierra Nevada, California: Implications for multistage evolution of a Jurassic arc terrane. Geology $19,180-184$.

Doglioni, C., Carminati, E., Cuffaro, M., Scrocca, D., 2007. Subduction kinematics and dynamic constraints. Earth-Sci. Rev. 83, 125-175.

Dostal, J., Mueller, W.U., 2013. Deciphering an Archean mantle plume: Abitibi greenstone belt, Canada. Gond. Res. 23, 493-505.

Dunning, G.R., Pedersen, R.B., 1988. U/Pb ages of ophiolites and arc-related plutons of the Norwegian Caledonides: implications for the development of Iapetus. Contrib. Mineral. Petrol. 98, 13-23.

El Bahat, A., Ikenne, M., Søderlund, U., Cousens, B., Youbi, N., Ernst, R., Soulaimani, A., El Janati, M., Hafid, A., 2013. U-Pb baddelyite ages and geochemistry of dolerite dikes in the Bas Draa Inlier of the Anti-Atlas of Morocco: newly identified 1380 Ma event in the West African Craton. Lithos 174, 85-98.

Elburg, M.A., van Bergen, M., Hoogewerfe, J., Foden, J., Vroon, P., Zulkarnain, I., Nasution, A., 2002. Geochemical trends across an arc-continent collision zone: magma source and slabwedge transfer processes below the Pantar Strait volcanoes, Indonesia. Geochim. Cosmochim. Acta 66, 2771-2789. 
1257

1258

1259

1260

1261

1262

1263

1264

1265

1266

1267

1268

1269

1270

1271

1272

1273

1274

1275

1276

1277

1278

1279

1280

1281

1282

1283

Erdmann, M., Fischer, L.A., France, L., Zhang, C., Godard, M., Koepke, J., 2015. Anatexis at the roof of an oceanic magma chamber at IODP Site 1256 (equatorial Pacific): an experimental study. Contrib. Mineral. Petrol. 164 (4), 1-28.

Escuder-Viruete, J., Pérez-Estaún, A., Joubert, M., Weis, D., 2011. The Pelona-Pico Duarte basalts Formation, Central Hispaniola: an on-land section of Late Cretaceous volcanism related to the Caribbean large igneous province. Geologica Acta 9 (3-4), 307-328.

Farahat, E.S., 2010. Neoproterozoic arc-back-arc system in the Central Eastern Desert of Egypt: Evidence from supra-subduction zone ophiolites. Lithos 120, 293-308.

Fareeduddin and Dilek, Y., 2015. Structure and Petrology of the Nagaland-Manipur Hill Ophiolite Melange Zone, NE India: A Fossil Tethyan Subduction Channel at the India - Burma Plate Boundary. Episodes 38, 298-314.

Flagler, P.A., Spray, J.G., 1991. Generation of plagiogranite by amphibolite anatexis in oceanic shear zones. Geology 19, 70-73.

Floyd, P.A., Winchester, J.A., 1975. Magma type and tectonic setting discrimination using immobile elements. Earth Planet. Sci. Lett. 27, 211-218.

Foulger, G.R., 2006. Older crust underlies Iceland. Geophys. J. Intern. 165, 672-676.

France, L., Koepke, J., Ildefonse, B., Cichy, S.B., Deschamps, F., 2010. Hydrous partial melting in the sheeted dike complex at fast spreading ridges: experimental and natural observations. Contrib. Mineral. Petrol. 160, 683-704.

Frey, F.A., Coffin, M.F., Wallance, P.J., Weis, D., Zhao, X., Wise, Jr. S.W., et al., 2000. Origin and evolution of a submarine large igneous province: the Kerguelen Plateau and Broken Ridge, southern Indian Ocean. Earth Planet. Sci. Lett. 176, 73-89.

Furnes, H., de Wit, M., Staudigel, H., Rosing, M., Muehlenbachs, K., 2007. A vestige of Earth's oldest ophiolite. Science 315, 1704-1707.

Furnes, H., Rosing, M., Dilek, Y., de Wit, M., 2009. Isua supracrustal belt (Greenland) - A vestige of a $3.8 \mathrm{Ga}$ suprasubduction zone ophiolite, and implications for Archean geology. Lithos 113, 115-132. 
1284 Furnes, H., Robins, B., de Wit, M.J., 2012a. Geochemistry and petrology of lavas in the upper

1285

1286

1287

1288

1289

1290

1291

1292

1293

1294

1295

1296

1297

1298

1299

1300

1301

1302

1303

1304

1305

1306

1307

1308

1309

1310

Onverwacht Suite, Barberton Mountain Land, South Africa. S. Afr. J. Geol. 115 (2), 171210.

Furnes, H., de Wit, M., Dilek, Y., 2014. Four billion years of ophiolites reveal secular trends in oceanic crust formation. Geosci. Front. 5, 571-603.

Furnes, H., Dilek, Y., de Wit, M., 2015. Precambrian greenstone sequences represent different ophiolite types. Gond. Res. 27, 649-685.

Gee, D.G., Fossen, H., Henriksen, N., Higgins, A.K., 2008. From the Early Paleozoic Platforms of Baltica and Laurentia to the Caledonide Orogen of Scandinavia and Greenland. Episodes $31(1), 44-51$.

Ghatak, A., Basu, A.R., Wakabayashi, J., 2011. Elemental mobility in subduction metamorphism: insight from metamorphic rocks of the Franciscan Complex and the Feather River ultramafic belt, California. Intern. Geol. Rev., iFirst article, 1-32.

Gillis, K.M., Coogan, L.A., 2002. Anatectic migmatites from the roof of an ocean ridge magma chamber. J. Petrol. 43 (11), 2075-2095.

Glen, R.A., 2005. The Tasmanides of eastern Australia. In: Vaughan, A.P.M., Leat, P.T., Pankhurst, R.J. (Eds.), Terrane Processes at the Margins of Gondwana. Geol. Soc., London, Spec. Publ. vol. 246, pp. 23-96.

Godfrey, N.J. and Dilek, Y., 2000 . Assimilation of oceanic crust/island arc into the North American continental margin: New insights from geophysical data: In, Ophiolites and Oceanic Crust: New Insights from Field Studies and Ocean Drilling Program, Geol. Soc. Am. Spec. Pap. vol. 349, pp. 371-387.

Gonzalez, C.M., Gorczyk, W., Gerya, T.V., 2015. Decarbonation of subducting slabs: Insight from petrological-thermomechanical modelling. Gond. Res. (in press); http://dx.doi.org/10.1016/j.gr.2015.07.011.

Grimes, C.B., Ushikubo, T., Kozdon, R., Valley, J.W., 2013. Perspectives on the origin of plagiogranite in ophiolites from oxygen isotopes in zircon. Lithos 179, 48-66. 
1311 Grove, T.L., Chatterjee, N., Parman, S.W., Médard, E., 2006. The influence of $\mathrm{H}_{2} \mathrm{O}$ on mantle

1312

1313

1314

1315

1316

1317

1318

1319

1320

1321

1322

1323

1324

1325

1326

1327

1328

1329

1330

1331

1332

1333

1334

1335

1336 wedge melting. Earth Planet. Sci. Lett. 249, 74-89.

Grove, T.L., Till, C.B., Lev, E., Chatterjee, N., Médard, E., 2009. Kinematic variables and water transport control the formation and location of arc volcanoes. Nature 459, 694-697; doi:10.1038/nature08044.

Gunnarsson, B., Marsh, B.D., Taylor Jr., H.P., 1998. Generation of Icelandic rhyolites: silicic lavas from the Torfajökull central volcano. J. Volc. Geotherm. Res. 83, 1-45.

Haase, K.M., Freund, S., Koepke, J., Hauff, F., Erdmann, M., 2015. Melts of sediments in the mantle wedge of the Oman ophiolite. Geology 43 (4), 275-278; doi: 10.1130/G3645.1.1.

Hall, R., 2012. Late Jurassic-Cenozoic reconstruction of the Indonesian region and the Indian Ocean. Tectonophysics 570-571, 1-41.

Hamilton, W.B., 1998. Archean magmatism and deformation were not the products of plate tectonics. Precamb. Res. 91, 109-142.

Hamilton, W.B., 2011. Plate tectonics began in Neoprotrozoic time, and plumes from deep mantle have never operated. Lithos 123, 1-20.

Harper, G.D., Wright, J.E., 1984. Middle to Late Jurassic tectonic evolution of the Klamath Mountains, California-Oregon. Tectonics 3, 759-772.

Hawkesworth, C.J., Turner, S.P., McDermott, F., Peate, D.W., van Calsteren, P., 1997. U-Th isotopes in arc magmas: implications for element transfer from subducted crust. Science $276,551-555$.

Heilimo, E., Halla, J., Höllä, P., 2010. Discrimination and origin of the sanukitoid series: Geochemical constraints from the Neoarchean western Karelian Province (Finland). Lithos 115, 27-39.

Henriksen, N., Higgins, A.K., Kalsbeek, F., Pulvertaft, T.C.R., 2009. Greenland from Archean to Quaternary. Descriptive text to the 1995 Geological map of Greenland, 1:2500000.

Geological Survey of Denmark and Greenland Bulletin 18, 126 pp + map. 
Hildebrand, R.S., 2013, Mesozoic assembly of the North American Cordillera: Geol. Soc. Am. Spec. Pap. vol. 495, 162 pp.

Hildreth, W., 1981. Gradients in silicic magma chambers: Implications for lithospheric magmatism. J. Geophys. Res. 86 (B11), 10153-10192.

Hofmann, A., Wilson, A.H., 2007. Silicified basalts, bedded cherts and other sea floor alteration phenomena of the 3.4 Ga Nondweni greenstone belt, South Africa. In: Van Kranendonk, M. J., Smithies, R. H., Bennett, V. C. (Eds.), Earth's Oldest Rocks. Developments in Precambrian Geology vol. 15, Elsevier, Amsterdam, pp. 571-605.

Hollis, S.P., Cooper, M.R., Roberts, S., Earls, G., Herrington, R., Condon, D.J., Daly, J.S., 2013. Evolution of the Tyrone ophiolite, Northern Ireland, during the Grampian-Taconic orogeny: A correlative of the Annieopsquotch Ophiolite Belt of central Newfoundland? J. Geol. Soc., London, 170, 861-876.

Hollocher, K., Robinson, P., Walsh, E., Roberts, D., 2012. Geochemistry of amphibole-facies volcanics and gabbros of the Støren Nappe in extensions west and southwest of Trondheim, Western Gneiss Region, Norway: A key to correlations and paleotectonic settings. Am. J. Sci. 312, 357-416.

Ingersoll, R.V., 2000. Models for Origin and Emplacement of Jurassic Ophiolites of Northern California. In: Geol. Soc. Am. Spec. Pap. vol. 349, pp. 395-402.

Isozaki, Y., 1997. Contrasting two types of orogen in Permo-Triassic Japan: Accretionary versus collisional. The Island Arc 6, 2-24.

Isozaki, Y., Aoki, K., Nakama, T., Yanai, S., 2010. New insight into into a subduction-related orogen: A reappraisal of the geotectonic framework and evolution of the Japanese islands. Gond. Res. 18, 82-105.

Jakobsen, J.K., Veksler, I.V., Tegner, C., Brooks, C.K., 2005. Immiscible iron- and silica-rich melts in basalt petrogenesis documented in the Skaergaard intrusion. Geology 33 (11), 885888 . 
1363

1364

1365

1366

1367

1368

1369

1370

1371

1372

1373

1374

1375

1376

1377

1378

1379

1380

1381

1382

1383

1384

1385

1386

1387

1388

1389

Jakobsson, S.P., Jónasson, K., Sigurdsson, I.A., 2008. The three igneous rock series of Iceland. Jökull 58, 117-138.

Jian, P., Liu, D., Kröner, A., Zhang, Q., Wang, Y., Sun, X., Zhang, W., 2009. Devonian to Permian plate tectonic cycle of the Paleo-Tethys Orogen in southwest China (I): Geochemistry of ophiolites, arc/back-arc assemblages and within-plate igneous rocks. Lithos 113, 748-766.

Jian, P., Liu, D., Kröner, A., Windley, B.F., Shi, Y., Zhang, W., Zhang, F., Miao, L., Zhang, L., Tomurhuu, D., 2010b. Evolution of Permian intraoceanic arc-trench system in the Solonker suture zone, Central Asian Orogenic Belt, China and Mongolia. Lithos 118, 169-190.

Johnson, S.P., Oliver, G.J.H., 2000. Mesoproterozoic oceanic subduction, island-arc formation and the initiation of back-arc spreading in the Kibaran Belt of central, southern Africa: evidence from the Ophiolite Terrane, Chevore Inliers, northern Zimbabwe. Precamb. Res. 103, 125-146.

Kelemen, P.B., Hanghøj, K., Greene, A.R., 2004. One view of the geochemistry of subductionrelated magmatic arcs, with an emphasis on primary andesite and lower crust, In: Holland, H.D., Turekian, K.K. (Eds.), Treatise on Geochemistry 3, 593-659.

Kerr, A.C., Tarney, J., Nivia, A., Mariner, G.F., Saunders, A.D., 1998. The internal structure of oceanic plateaus: inferences from obducted Cretaceous terranes in western Colombia and the Caribbean. Tectonophysics 292,173-188.

Koepke, J., Feig, S.T., Snow, J., Freise, M., 2004. Petrogenesis of oceanic plagiogranites by partial melting of gabbros: an experimenal study. Contrib. Mineral. Petrol. 146, 414-432.

Koepke, J., Berndt, J., Feig, S.T., Holtz, F., 2007. The formation of $\mathrm{SiO}_{2}$-rich melts within the deep oceanic crust by hydrous partial melting of gabbros. Contrib. Mineral. Petrol. 153, 6784.

Komiya, T., Maruyama, S., Hirata, T., Yurimoto, H., Nohda, S., 2004. Geochemistry of the oldest MORB and OIB in the Isua Supracrustal Belt, southern West Greenland: implications for the composition and temperature of early Archean upper mantle. Island Arc 13 (1), 47-72. 
1390

1391

1392

1393

1394

1395

1396

1397

1398

1399

1400

1401

1402

1403

1404

1405

1406

1407

1408

1409

1410

1411

1412

1413

1414

1415

Kounov, A., Graf, J., von Quadt, A., Bernoulli, D., Burg, J-P., Seward, D., Ivanov, Z., Fanning, M., 2012. Evidence for a "Cadomian" ophiolite and magmatic-arc complex in SW Bulgaria. Precamb. Res. 212-213, 275-295.

Kroner, U., Romer, R.L., 2013. Two plates - Many subduction zones: The Variscan orogeny reconsidered. Gond. Res. 24, 298-329.

Kröner, A., Hegner, E., Lehmann, B., Heinhorst, J., Wingate, M.T.D., Liu, D.Y., Ermelow, P., 2008. Paleozoic arc magmatism in the Central Asian Orogenic Belt of Kazakhstan: SHRIMP zircon ages and whole-rock Nd isotopic systematics. J. Asian Earth Sci. 32, 118130.

Kusky, T.M. (Ed.), 2004. Precambrian Ophiolites and Related Rocks. Developments in Precambrian Geology, vol. 13, 772 pp.

Le Bas, M.J., Streckeisen, A.L., 1991. The IUGS systematics of igneous rocks. J. Geol. Soc., London, 148, 825-833.

Li, X-H., Zhao, J-X., McCulloch, M.T., Zhou, G-Q., Xing, F-m., 1997. Geochemical and Sm-Nd isotopic study of Neoproterozoic ophiolites from southeastern China: Petrogenesis and tectonic implications. Precamb. Res. 81, 129-144.

Li, Y., Yang, J.-S., Dilek, Y., Zhang, J., Pei, X.-Z., Chen, S.-Y., Xu, X.-Z., and Li, J.-Y., 2015. Crustal architecture of the Shangdan suture zone in the early Paleozoic Qinling orogenic belt, China: Record of subduction initiation and backarc basin development. Gond. Res. 27, 733-744.

Liao, J., Gerya, T., 2015. From continental drift to seafloor spreading: Insight from 3D thermomechanical modeling. Gond. Res. 28 (4), 1329-1343.

Linnemann, U., Pereira, F., Jeffries, T.E., Drost, K., Gerdes, A., 2008. The Cadomian Orogeny and the opening of the Rheic Ocean: The diachrony of geotectonic processes constrained by LA-ICP-MS U-Pb zircon dating (Ossa-Morena and Saxo-Thuringian Zones, Iberian and Bohemian Massifs). Tectonophysics 461 (1-4), 21-43. 
1416

1417

1418

1419

1420

1421

1422

1423

1424

1425

1426

1427

1428

1429

1430

1431

1432

1433

1434

1435

1436

1437

1438

1439

1440

Lundstrom, C.C., Glazner, A.F., 2016. Silicic magmatism and the volcanic-plutonic connection. Elements 12, 91-96.

Majer, V., Garašič, V., 2001. Plagiogranites from the ophiolitic complexes of Dinarides and Vardar Zone. Rudasko-geološko-nafti zbornik 13, 1-7.

Malpas, J., 1979. Two contrasting trondhjemite associations from transported ophiolites in western Newfoundland: initial report. In: Barker, F. (Ed.), Trondhjemites, Dacites and Related Rocks. Elsevier, New York, pp. 465-487.

Manatschal, G., Müntener, O., 2009. A type sequence across an ancient magma-poor oceancontinent transition: The example of the western Alpine Tethys ophiolites. Tectonophysics 473, 4-19.

Martin, H., 1999. Adakitic magmas: modern analogues of Archean granitoids. Lithos 46, 411429.

Martin, H., Smithies, R. H., Rapp, R., Moyen, J.-F., Champion, D., 2005. An overview of adakite, tonalite-trondhjemite-granodiorite (TTG), sanukitoid: relationships and some implications for crustal evolution. Lithos 79, 1-24.

Masters, R.L., Ague, J.J., 2005. Regional-scale fluid flow and element mobility in Barrow's metamorphic zones, Stonehaven, Scotland. Contrib. Mineral. Petrol. 150, 1-18.

Matte, P., 1991. Accretionary history and crustal evolution of the Variscan belt in Western Europe. Tectonophyscis 196, 309-337.

McDonough, W.F., Sun, S.-S. 1995. The composition of the earth. Chem. Geol. 120, 223-253.

Miyashiro, A., 1973. The Troodos complex was probably formed in an island arc: Earth Planet. Sci. Lett. 19, 218-224.

Miyashiro, A., 1975. Classification, characteristics, and origin of ophiolites. J. Geol. 83, 249-281.

Moores, E.M., Vine, F.J., 1971. The Troodos massif, Cyprus, and other ophiolites as oceanic crust: evaluation and implications. Phil. Trans. Royal Soc. London 268A, 443-466. 
1441

1442

1443

1444

1445

1446

1447

1448

1449

1450

1451

1452

1453

1454

1455

1456

1457

1458

1459

1460

1461

1462

1463

1464

1465

1466

1467

1468

Murphy, J.B., McCausland, P.J.A., O'Brien, S.J., Pisarevsky, S., Hamilton, M.A., 2008. Age, geochemistry and Sm-Nd isotopic signature of the 0.76 Ga Burin Group: Compositional equivalent of Avalonian basement? Precamb. Res. 165, 37-48.

Mukhopadhyay, J., Ghosh, G., Zimmermann, U., Guha, S., Mukherjee, T., 2012. A $3.51 \mathrm{Ga}$ bimodal volcanics-BIF-ultramafic succession from Singhbhum Craton: implications for Palaeoarchaean geodynamic processes from the oldest greenstone succession of the Indian subcontinent. Geol. J. 47, 284-31.

Mysen, B.O., Boettcher, A.L., 1975. Pressures and temperatures with controlled activities of water, carbon dioxide, and hydrogen. J. Petrol. 16 (3), 520-548.

Naqvi, S.M., Khan, R.M.K., Manikyamba, C., Ram Mohan, M., Khanna, T.C., 2006.

Geochemistry of the NeoArchaean high-Mg basalts, boninites and adakites from the Kushtagi-Hungund greenstone belt of the Eastern Dharwar Craton (EDC); implications for tectonic setting. J. Asian Earth Sci. 27, 25-44.

Nutman, A.P., Bennett, V.C., Friend, C.R.L., Rosing, M.T., 1997. 3710 and $\geq 3790$ Ma volcanic sequences in the Isua (Greenland) supracrustal belt; structural and Nd isotope implications. Chem. Geol. 141, 271-287.

Oncken, O., Cheng, G., Franz, G., Giese, P., Götze, H-J., Ramos, V.A., Strecker, M.R., Wigger, P. (Eds.), 2006. The Andes - Active Subduction Orogeny. Frontiers in Earth Sciences, Springer Berlin, Heidelberg, 569 pp.

Palin, R.M., White, R.W., 2016. Emergence of blueschists on Earth linked to secular changes in oceanic crust composition. Nature Geosci. 9, 60-64.

Pearce, J.A., Parkinson, I.J., 1993. Trace element models for mantle melting: application to volcanic arc petrogenesis. In: Prichard HM, Alabaster, T., Harris, N.B.W., Neary, C.R. (Eds.), Magmatic Processes and Plate Tectonics, Geol. Soc., London, Spec. Publ., vol. 76, pp. 373-403.

Pearce, J.A., 2003. Supra-subduction zone ophiolites: The search for modern analogues. In, Dilek, Y. \& Newcomb, S. (Eds.) Ophiolite Concept and the Evolution of Geological Thought, Geol. Soc. Am. Spec. Paper, vol. 373, pp. 269-293. 
1469

1470

1471

1472

1473

1474

1475

1476

1477

1478

1479

1480

1481

1482

1483

1484

1485

1486

1487

1488

1489

1490

1491

1492

1493

1494
Pearce, J.A., 2008. Geochemical fingerprinting of oceanic basalts with implications for the classification of ophiolites and search for Archean oceanic crust. Lithos 100, 14-48.

Pearce, 2014. Ophiolites: Immobile Elements Fingerprinting of Ophiolites. Elements 10 (2), 101108.

Pearce, J.A., Stern, R.J., Bloomer, S.H., Fryer, P., 2005. Geochemical mapping of the Mariana arc-basin system: Implications for the nature and distribution of subduction component. Geochem. Geophys. Geosyst. 6 (7), Q07006, doi:10.1029/2004GC000895.

Pedersen, R.B., Hertogen, J., 1990. Magmatic evolution of the Karmøy Ophiolite Complex, SW Norway: relationships between MORB-IAT-boninitic-calc-alkaline and alkaline magmatism. Contrib. Mineral. Petrol. 104, 277-293.

Pedersen, R.B., Furnes, H., Dunning, G., 1991. A U/Pb age for the Sulitjelma Gabbro, North Norway: further evidence for the development of a Caledonian marginal basin in AshgillLlandovery time. Geol. Mag. 128, 141-143.

Peng, S., Kusky, T.M., Jiang, X.F., Wang, L., Wang, J.P., Deng, H., 2012. Geology, geochemistry, and geochronology of the Miaowan ophiolite, Yangtze craton: Implications for South China's amalgamation history with the Rodinian supercontinent. Gond. Res. 21, 577-594.

Philpotts, A.R., 1982. Compositions of immiscible liquids in volcanic rocks. Contrib. Mineral. Petrol. 80, 201-218.

Plank. T., 2005. Constraints from Thorium/Lanthanum on sediment recycling at subduction zones and the evolution of the continents. J. Petrol. 46 (5), 921-944.

Plank, T., Langmuir, C.H., 1998. The chemical composition of subducting sediment and its consequences for the crust and mantle. Chem. Geol. 145, 325-394.

Polat, A., Kerrich, R., 2000. Archean greenstone belt magmatism and the continental growthmantle evolution connection: constraints from Th-U-Nb-LREE systematics of the $2.7 \mathrm{Ga}$ Wawa subprovince, Superior Province, Canada. Earth Planet. Sci. Lett. 175, 41-54. 
1495 1496

1497

1498

1499

1500

1501

1502

1503

1504

1505

1506

1507

1508

1509

1510

1511

1512

1513

1514

1515

1516

1517

1518

1519

1520

1521

Polat, A., Kerrish, R., Wyman, D.A., 1999. Geological diversity in oceanic komatiites and basalts from the late Archean Wawa greenstone belts, Superior Province, Canada: trace elements and Nd isotope evidence for a heterogeneous mantle. Precamb. Res. 94, 139-173.

Pushkov, V.N., 2009. The evolution of the Uralian orogen. In: Murphy, J.B., Keppie, J.D., Hynes, A.J. (Eds.), Ancient Orogens and Modern Analogues. Geol. Soc. Spec. Publ., vol. 327, pp. 161-195.

Ramos, V.A., 2009. Anatomy and global context of the Andes: Main geologic features and the Andean orogenic cycle. In: Kay, S.M., Ramos, V.A., Dickinson, W.R. (Eds.), Backbone of the Americas: Shallow Subduction, Plateau Uplift, and Ridge and Terrane Collision. Geol. Soc. Am. Mem., vol. 204, pp. 31-65.

Rao, D.R., Rai, H., Kumar, J.S., 2004. Origin of oceanic plagiogranite in the Nidar ophiolitic sequence of eastern Ladakh, India. Current Sci. 87 (7), 999-110.

Ridley, W.I., 2012. Petrology of associated igneous rocks in volcanogenic massive sulfide occurrence model. U.S. Geological Survey Scientific Investigations Report 2010-5070-C, chap. $15,32 \mathrm{pp}$.

Roberts, D., Nordgulen, Ø., Melezhik, V., 2007. The Uppermost Allochthon in the Scandinavian Caledonides: From a Laurentian ancestry through Taconian orogeny to Scandian crustal growth on Baltica. In: Hatcher, R.D., Jr., Carlson, M.P., McBride, J.H., Martínez Catalán, J.R. (Eds.), 4-D Framework of Continental Crust. Geol. Soc. Am. Mem., vol. 200, pp. 357377.

Robertson, A.H.F., 2000. Mesozoic-Tertiary tectonic-sedimentary evolution of a south Tethyan oceanic basin and its margins in southern Turkey. In: Winchester, J.A., Piper, J.D.A. (Eds.), Tectonics and Magmatism in Turkey and the Surrounding Area. Geol. Soc., London, Spec. Publ., vol. 173, pp. 97- 138.

Robinson, P.T., Malpas, J., Dilek, Y., Zhou, M.-F., 2008. The significance of sheeted dike complexes in ophiolites. GSA Today 18 (11), 4-10. http://dx.doi.org/1130/GSAT22A.1.

Rollinson, H., 1993. Using Geochemical Data: Evaluation, Presentation, Interpretation. Longman, 
London, $352 \mathrm{pp}$.

Rollinson, H., 2009. New models for the genesis of plagiogranites in the Oman ophiolite. Lithos 112, 603-614.

Rollinson, H., 2014. Plagiogranites from the mantle section of the Oman Ophiolite: models for early crustal evolution. In: Rollinson, H.R., Searle. M.P., Abbasi, I.A., Al-Lazki, A., Al Kind, M.H. (Eds.), Tectonic Evolution of the Oman Mountains. Geol. Soc., London, Spec. Publ., vol. 392, pp. 247-261.

Rossetti, F., Nozaem, R., Lucci, F., Vignaroli, G., Gerdes, A., Nasrabadi, M., Theye, T., 2015. Tectonic setting and geochronology of the Cadomian (Ediacaran-Cambrian) magmatism in Ventral Iran, Kuh-e-Sarhangi region NW Lut Block). J. Asian Earth Sci. 102, 24-44.

Ryazantsev, A.V., Dubinina, S.V., Kuznetsov, N.B., Belova, A.A., 2008. Ordovician lithotectonic complexes in allochthons of the Southern Urals. Geotectonics 42 (5), 368-395.

Saccani, E., Dilek, Y., Marroni, M., Pandolfi, L., 2015. Continental margin ophiolites of Neotethys: Remnants of Ancient Ocean-Continent Transition Zone (OCTZ) lithosphere and their geochemistry, mantle sources and melt evolution patterns. Episodes 38, DOI:10.18814/epiiugs/2015/v38i4/82418.

Saemundsson, K., 1979. Outline of geology of Iceland. Jökull 29, 7-28.

Saleeby, J.B., 1983. Accretionary tectonics of the North American Cordillera. Ann. Rev. Earth Planet. Sci. 15, 45-73.

Sarifakioglu, E., Dilek, Y., and Sevin, M., 2014. Jurassic-Paleogene intra-oceanic magmatic evolution of the Ankara Mélange, North Central Anatolia, Turkey. Solid Earth 5, 77-108, DOI: 10.5194/se-5-77-2014.

Sawaki, Y., Shibuya, T., Kawai, T., Komiya, T., Omori, S., Iizuka, T., Hirata, T., Windley, B.F., Maruyama, S., 2010. Imbricated ocean-plate stratigraphy and U-Pb zircon ages from tuff beds in cherts in the Ballantrae complex, SW Scotland. Geol. Soc. Am. Bull. 122 (3/4), 454464. 
1548 Scaillet, B., Holtz, F., Pichavant, M., 2016. Experimental constraints on the formation of silicic 1549 magmas. Elements 12, 109-114.

1550

1551

1552

1553

1554

1555

1556

1557

1558

1559

1560

1561

1562

1563

1564

1565

1566

1567

1568

1569

1570

1571

1572

1573

1574

Scott, R.B., Hajash Jr., A., 1976. Initial submarine alteration of basaltic pillow lavas: A microprobe study. Am. J. Sci. 276, 480-501.

Seifert, K.E., Chang, C-W., and Brunotte, D.E., 1997, Evidence from Ocean Drilling Program Leg 149 mafic igneous rocks for oceanic crust in the Iberia Abyssal Plain ocean-continent transition zone. J. Geophys. Res. 102 (B4), 7915-7928.

Seyfried, W.E., Berndt, M.E., Seewald, J.S., 1988. Hydrothermal alteration processes at midocean ridges: constraints from diabase alteration experiments, hot-spring fluids and composition of the oceanic crust. Can. Mineral. 26, 787-804.

Shervais, J.W., 1982. Ti-V plots and the petrogenesis of modern and ophiolitic lavas. Earth Planet. Sci. Lett. 32, 114-120.

Shin, K.-C., Anma, R., Nakano, T., Orihashi, Y., and Ike, S.-I., 2015. The Taitao ophiolite-granite complex, Chile: Emplacement of ridge-trench intersection oceanic lithosphere on land and the origin of calc-alkaline I-type granites. Episodes 38, 283-296.

Silantyev, S.A., Aranovich. L.La., Bortnikov, N.S., 2010. Oceanic plagiogranites as a result of interaction between magmatic and hydrothermal systems in the slow-spreading mid-ocean ridges. Petrology 18 (4), 369-383.

Silantyyev, S.A., Krasnova, E.A., Cannat, M., Bortnikov, N.S., Kononkova, N.N., Beltenev, V.E., 2011. Peridotite-gabbro-trondhjemite association of the Mid-Atlantic Ridge between $12^{\circ} 58^{\prime}$ and $14^{\circ} 45^{\prime} \mathrm{N}$ : Ashadze and Logachev hydrothermal vent fields. Geochem. Intern. 49 (4), 323-323.

Skruf'in, P.K., Theart, H.F.J., 2005. Geochemical and tectono-magmatic evolution of the volcano-sedimentary rocks of Pechenga and other greenstone fragments within the Kola Greenstone Belt, Russia. Precamb. Res. 141, 1-48.

Schimdt, M.W., Poli, S., 1998. Experimentally based water budgets for dehydrating slabs and consequences for arc magma generation. Earth Planet. Sci. Lett. 163, 361-379. 
1575

1576

1577

1578

1579

1580

1581

1582

1583

1584

1585

1586

1587

1588

1589

1590

1591

1592

1593

1594

1595

1596

1597

1598

1599

1600

1601

1602

Smithies, R.H., Champion, D.C., Van Kranendonk, M.J., Howard, H.M., Hickman, A.H., 2005. Modern-style subduction processes in the Mesoarchaean: geochemical evidence from the 3.12 Ga Whundo intra-oceanic arc. Earth Planet. Sci. Lett. 231, 221-237.

Song, S., Niu, Y., Su, L., Zia, X., 2013. Tectonics of the North Qilian orogen, NW China. Gond. Res. 23, 1378-1401.

Spadea, P., D'Antonio, M., 2006. Initiation and evolution of intra-oceanic subduction in the Uralides: Geochemical and isotopic constraints from Devonian oceanic rocks of the Southern Urals, Russia. Island Arc 15, 7-25.

Spaggiari, C.V., Gray, D.R., and Foster, D.A., 2003. Tethyan- and Cordilleran-type ophiolites of eastern Australia: implications for the evolution of Tasmanides. In, Dilek, Y. and Robinson, P.T. (Eds.), Ophiolites in Earth History, Geol. Soc., London, Spec. Publ., vol. 218, pp. 517-539.

Spulber, S.D., Rutherford, M.J., 1983. The origin of rhyolite and plagiogranite in oceanic crust: An experimental study. J. Petrol. 47 (1), 1-25.

Stampfli, G.M., Hochard, C., 2009. Plate tectonics of the Alpine realm. In: Murphy, J.B., Keppie, J.D., Hynes, A.J. (Eds.), Ancient Orogens and Modern Analogues. Geol. Soc. Spec. Publ., vol. 327, pp. 89-111.

St-Onge, M.R., Lucas, S.B., Scott, D.J., 1997. The Ungava orogen and the Cape Smith thrust belt. In: de Wit, M.J., Ashwal, L.D. (Eds.), Greenstone Belts. Oxford University Press, Oxford, U.K, pp. 772-780.

Staudigel, H., Hart, R., 1983. Alteration of basaltic glass: mechanism and significance for the oceanic crust-seawater budget. Geochim. Cosmochim. Acta 47, 37-50.

Sylvester, P.J., Harper, G.D., Byerly, G.R., Thurston, P.C., 1997. Volcanic aspects of greenstone belts. In: de Wit, M.J., Ashwal, L.D. (Eds.), Greenstone Belts. Oxford University Press, Oxford, U.K., pp. 55-90.

Tatsumi, Y., Kogiso, T., 1997. Trace element transport during dehydration processes in the subducted oceanic crust: 2 . Origin of chemical and physical characteristics in arc magmatism. Earth Planet. Sci. Lett. 148, 207-221. 
Thayer, T.P., 1977. Some implications of sheeted dike swarms in ophiolitic complexes. Geotectonics 11, 419-426.

Van Kranendonk, M.J., Pirajno, P., 2004. Geochemistry of metabasalts and hydrothermal alteration zones associated with c. $3.45 \mathrm{Ga}$ chert and barite deposits: implications for the geological setting of the Warrawoona Group, Pilbara Craton, Australia. Geochemistry, Exploration, Environment, Analysis 4, 253-278.

Van Kranendonk, M.J., Smithies, R.H., Hickman, A.H., Champion, D.C., 2007. Review: secular tectonic evolution of Archean continental crust: interplay between horizontal and vertical processes in the formation of the Pilbara Craton, Australia. Terra Nova 19 (1), 1-38.

van Staal, C.R., Whalen, J.B., Valverde-Vaquero, P., Zagorevski, A., Rogers, N., 2009. PreCarboniferous, episodic accretion-related, orogenesis along the Laurentian margin of the northern Appalachians. In: Murphy, J.B., Keppie, J.D., Hynes, A.J. (Eds.), Ancient Orogens and Modern Analogues. Geol. Soc., London, Spec. Publ., vol. 327, pp. 271-316.

Veksler, I.V., Dorfman, A.M., Borisov, A.A., Wirth, R., Dingwell, D.B., 2007. Liquid immiscibility and the evolution of basaltic magma. J. Petrol. 48 (11), 2187-2210.

Veloso, E.A.E., Anma, R., Yamazaki, T., 2005. Tectonic rotations during the Chile Ridge collision and obduction of the Taitao ophiolite (southern Chile). The Island Arc 14, 599615.

Veloso, E.E., Anma, R., Yamaji, A., 2009. Ophiolite Emplacement and the Effects of the Subduction of the Active Chile Ridge System: Heterogeneous Paleostress Regimes Recorded in the Taitao Ophiolite (Southern Chile). Andean Geology 36 (1), 3-16.

Vidal, M., Alric, G., 1994. The Palaeoproterozoic (Birimian) of Haute-Comoé in the West Africa Craton, Ivory Coast: a transtensional back-arc basin. Precamb. Res. 65, 207-229.

Wakita, K., Bubellier, M., Windley, B.F., 2013. Tectonic processes, from rifting to collision via subduction, in SE Asia and the western Pacific: A key to understanding the architecture of the Central Asian Orogenic Belt. Lithosphere 5 (3), 265-276.

Walker, G.P.L., 1966. Acid volcanic rocks in Iceland. Bull. Volcan. 29 (1), 375-402. 
Walker, G.P.L., 1975. Intrusive sheet swarms and the identity of Crustal Layer 3 in Iceland. J. Geol. Soc. London, 131, 143-161.

Walker, J.D., Geissman, J.W., Bowring, S.A., Babcock, L.E., 2013. The Geological Society of America Geologic Time Scale. Geol. Soc. Am. Bull. 125 (3/4), 259-272.

Watanabe, S., Widom, E., Ui, T., Miyaji, N., Roberts, A.M., 2006. The evolution of a chemically zoned magma chamber: The 1707 eruption of Fuji volcano, Japan. J. Volc. Geotherm. Res. $152,1-19$.

Widom, E., Schmincke, H.-U., Gill, J.B., 1992. Processes and timescales in the evolution of a chemically zoned trachyte: Fogo A, Sao Miguel, Azores. Contrib. Mineral. Petrol. 111, 311-328.

Wilhem, C., Windley, B.F., Stampfli, G.M., 2011. The Altaids of Central Asia: A tectonic and evolutionary innovative review. Earth-Sci. Rev. 113, 303-341.

Windley, B.F., Alexeiev, D., Xiao, W., Kröner, A., Badarch, G., 2007. Tectonic models for accretion of the Central Asian Orogenic Belt. J. Geol. Soc., London, 164, 31-47.

Xu, Y-G., He, B., Chung, S-L., Menzies, M.A., Frey, F.A., 2004. Geologic, geochemical, and geophysical consequences of plume involvement in the Emeishan flood-basalt province. Geology 32 (10), 917-920; doi: 10.1130/G20602.1.

Yellappa, T., Chetty, T.R.K., Tsunogae, T., Santosh, M., 2010. The Manamedu Complex: Geochemical constraints on Neoproterozoic suprasubduction zone ophiolite formation within the Gondwana suture in southern India. J. Geodynamics 50, 268-285.

Yibas, B., Reimold, W.U., Anhaeusser, C.R., Koeberl, C., 2003. Geochemistry of the mafic rocks of the ophiolitic fold and thrust belts of southern Ethiopia: constraints on the tectonic regime during the Neoproterozoic (900-700 Ma). Precamb. Res. 121, 157-183.

Yin, J., Chen, W., Yuan, C., Yu, S., Xiao, W., Long, X., Li, J., Sun, J., 2015. Petrogenesis of Early Carboniferous adakitic dikes, Sawur region, northern West Junggar, NW China: implications for geodynamic evolution. Gond. Res. 27, 1630-1645. 
1656 Zagorevski, A., van Staal, C.R., 2011. The record of Ordovician arc-arc and arc-continent 1657 collisions in the Canadian Appalachians during the closure of Iapetus. In: Brown, D., Ryan, 1658 P.D. (Eds.), Arc-Continent Collisions. Frontiers in Earth Sciences, Springer-Verlag, Berlin $1659 \quad$ Heidelberg, pp. 341-371.

1660 Zheng, R., Wu, T., Zhang, W., Xu, C., Meng, Q., 2013. Late Paleozoic subduction system in the 1661 southern Central Asian Orogenic Belt: Evidences from geochronology and geochemistry of 1662 1663 Zeng, L., Niu, H., Bao, Z., Shan, Z., Li, H., Yang, W., 2015. Petrogenesis and tectonic 1664 significance of the plagiogranites in the Zhaheba ophiolite, Eastern Junggar orogen, 1665 Xinjang, China. J. Asian Earth Sci. 113, 137-150.

1666 Zhou, G., 1989. The discovery and significance of the northeastern Jiangxi Province ophiolite 1667 (NEJXO), its metamorphic peridotite and associated high temperature-high pressure 1668 metamorphic rocks. J. SE Asian Sci. 3 (1-4), 237-247.

1669 Zwart, H.J., 1967. The duality of orogenic belts. Geologie en Mijnbouw 46, 283-309. 


\section{Figure and Table Captions}

Fig. 1. Schematic plate tectonic diagram (not to scale), depicting the major settings of magmatic construction of the oceanic lithosphere (above) and the structural architecture of the main types of oceanic lithosphere, developed in these settings (below). Modified from Dilek and Furnes $(2011,2014)$. See text for further discussion.

Fig. 2. Columnar section showing the upper mantle and crustal components of a generalized subduction-related ophiolite (modified from Dilek and Furnes, 2014). Photo 1: Massive andesite flows, Mirdita ophiolite, Albania; Photo 2: Silicic intrusions crosscutting the plutonic gabbro and dike swarms, Karmøy ophiolite, Western Norway; Photo 3: Silicic dike crosscutting a coarse-grained, brecciated gabbro, Eldivan ophiolite, Turkey; Photo 4: Silicic dike crosscutting mafic and ultramafic cumulates, Mirdita ophiolite, Albania; Photo 5: Silicic intrusions (strongly deformed) in the upper mantle harzburgite, Xigaze ophiolite, Southern Tibet.

Fig. 3. A ternary An-Ab-Or diagram depicting the feldspar compositional variations among various silicic rock types in different ophiolites (Barker, 1979), including plagiogranites of crustal origin (e.g., Oman ophiolite: Rollinson, 2014; Nidar ophiolite: Rao et al., 2004; Mawat ophiolite: Mirza and Ismail, 2007; the Central Dinaride Ophiolite Belt (CDOB) and the Vardar Zone Ophiolite Belt (VZOB): Majer and Garašič, 2001) and those of mantle origin (e.g., Oman: Rollinson, 2014). Fields of experimental felsic melts produced by partial melting of gabbro (Koelpe et al., 2004) and Archean TTGs (after Rollinson, 2014) are also shown.

Fig. 4. Various tectonic discrimination diagrams used in this study for the first-order classification and discrimination of the tectonic settings of formation of ophiolitic crustal units (after Pearce, 2014). The $\mathrm{Zr} / \mathrm{Ti}$ - Nb/Y diagram is originally after Floyd and Winchester (1975), the $\mathrm{Th} / \mathrm{Yb}-\mathrm{Nb} / \mathrm{Yb}$ and $\mathrm{TiO}_{2} / \mathrm{Yb}-\mathrm{Nb} / \mathrm{Yb}$ diagrams after Pearce (2008), and the V - Ti/1000 diagram after Shervais (1982).

Fig. 5. All intermediate and silicic rocks of the subduction-unrelated and subduction-related ophiolites plotted in a $\mathrm{Zr} / \mathrm{Ti}-\mathrm{Nb} / \mathrm{Y}$ diagram. 
1698

1699

1700

1701

1702

1703

1704

1705

1706

1707

1708

1709

1710

1711

1712

1713

1714

1715

1716

1717

1718

1719

1720

1721

1722

1723

Fig. 6. Percentage intermediate (basaltic andesite, andesite, and trachyandesite) and silicic (rhyolite and trachyte) rocks in subduction-unrelated (A), and subduction-related (B) ophiolites.

Fig. 7. Harker diagrams for subduction-unrelated ophiolites.

Fig. 8. Harker diagrams for subduction-related ophiolites.

Fig. 9. Chondrite-normalized REE diagrams and the distribution of $(\mathrm{La} / \mathrm{Lu})_{\mathrm{N}}$ ratios of intermediate to silicic rocks of Rift/Continental margin ophiolites. Chondrite data from McDonough and Sun (1995).

Fig. 10. Chondrite-normalized REE diagrams and the distribution of $(\mathrm{La} / \mathrm{Lu})_{\mathrm{N}}$ ratios of intermediate to silicic rocks of MOR ophiolites. Chondrite data as in Fig. 9.

Fig. 11. Chondrite-normalized REE diagrams and the distribution of $(\mathrm{La} / \mathrm{Lu})_{\mathrm{N}}$ ratios of intermediate to silicic rocks of Plume/MOR ophiolites. Chondrite data as in Fig. 9.

Fig. 12. Chondrite-normalized REE diagrams and the distribution of $(\mathrm{La} / \mathrm{Lu})_{\mathrm{N}}$ ratios of intermediate to silicic rocks of back-arc ophiolites. Black lines have been used to emphasize those patterns that crosscut the majority of lines. Chondrite data as in Fig. 9.

Fig. 13. Chondrite-normalized REE diagrams and the distribution of $(\mathrm{La} / \mathrm{Lu})_{N}$ ratios of intermediate to silicic rocks of backarc to fore-arc ophiolites. Black lines have been used to emphasize those patterns that crosscut the majority of lines. Chondrite data as in Fig. 9.

Fig. 14. Chondrite-normalized REE diagrams and the distribution of $(\mathrm{La} / \mathrm{Lu})_{\mathrm{N}}$ ratios of intermediate to silicic rocks of fore-arc ophiolites. Black lines have been used to emphasize those patterns that crosscut the majority of lines. Chondrite data as in Fig. 9.

Fig. 15. Chondrite-normalized REE diagrams and the distribution of $(\mathrm{La} / \mathrm{Lu})_{\mathrm{N}}$ ratios of intermediate to silicic rocks of volcanic-arc ophiolites. Chondrite data as in Fig. 9.

Fig. 16. N-MORB-normalized multi-element diagrams of intermediate to silicic rocks of Rift/Continental margin and MOR ophiolites. N-MORB values are from Pearce and Parkinson (1993). 
1724 Fig. 17. N-MORB-normalized multi-element diagrams of intermediate to silicic rocks of Plume/MOR ophiolites. N-MORB values as in Fig. 16.

1726

1727

1728

1729

1730

1731

1732

1733

1734

1735

1736

1737

1738

1739

1740

1741

1742

1743

1744

1745

1746

1747

1748

1749

1750 and backarc to fore-arc ophiolites. N-MORB values as in Fig. 16.

Fig. 19. N-MORB-normalized multi-element diagrams of intermediate to silicic rocks of fore-arc and volcanic-arc ophiolites. N-MORB values as in Fig. 16.

Fig. 20. Histograms (in percentage) showing $\mathrm{Nb}$-anomalies in subduction-unrelated and subduction-related ophiolites. The anomalies have been calculated on the basis of MORBnormalized values of the adjacent elements Th, Nb, La (Figs. 15-18), using the formula $[(\mathrm{Th}+\mathrm{La}) / 2-\mathrm{Nb}]_{\mathrm{N}}$.

Fig. 21. Histograms (in percentage) showing Eu-anomalies in subduction-unrelated and subduction-related ophiolites. The anomalies have been calculated on the basis of chondrite-normalized values of adjacent elements Sm, Eu, Gd (Figs. 8-14), using the formula $[(\mathrm{Sm}+\mathrm{Gd}) / 2-\mathrm{Eu}]_{\mathrm{N}}$.

Fig. 22. Histograms (in percentage) showing Ti-anomalies in subduction-unrelated and subduction-related ophiolites. The anomalies have been calculated on the basis of MORBnormalized values of adjacent elements $\mathrm{Gd}$, Ti, Dy (Figs. 15-18), using the formula $\left[\left(\mathrm{TiO}_{2}\right.\right.$ $-(\mathrm{Gd}+\mathrm{Dy}) / 2)]_{\mathrm{N}}$.

Fig. 23. Modeled variations in the enrichment factor $\left(\mathrm{C}_{1} / \mathrm{C}_{0}\right)$ for La with an increasing $\mathrm{SiO}_{2}$ content during (A) batch melting, and (B) fractional crystallization (after Brophy, 2009). (C) $\mathrm{La}-\mathrm{SiO}_{2}$ diagram of mafic to felsic rocks of subduction-unrelated ophiolites. The diagram includes models curves for partial melting and fractional crystallization (modified from Brophy, 2009). See text for further details.

Fig. 24. $\mathrm{La}-\mathrm{SiO}_{2}$ diagram of mafic to felsic rocks in subduction-related ophiolites. The superimposed curves for partial melting and fractional crystallization are modified from Brophy (2009). The black arrows indicate fractional crystallization of the produced melts See text for further details. 
1751

1752

1753

1754

1755

1756

1757

1758

1759

1760

1761

1762

1763

1764

1765

1766

1767

1768

1769

1770

1771

1772

1773

1774

1775

1776

1777

1778

1779

Fig. 25. Intermediate to silicic rocks plotted in $\mathrm{Sr} / \mathrm{Y}-\mathrm{Y}$ diagrams $(\mathrm{A}, \mathrm{B}, \mathrm{C})$ showing adakite and ADR (andesite, dacite, rhyolite) fields. Modified after Castillo (2006) and Naqvi et al. (2006). Diagrams (D, E. F) that separate high- $-\mathrm{SiO}_{2}$ and low- $\mathrm{SiO}_{2}$ adakites are from Martin et al. (2005).

Fig. 26. Proxies for shallow $(\mathrm{Ba} / \mathrm{Th})$, deep $(\mathrm{Th} / \mathrm{Nb})$, and total $(\mathrm{Ba} / \mathrm{Th})$ subduction, plotted against Th. All values are MORB-normalized. For the last three diagrams showing "summary of averages", "Felsic" refers to the intermediate and silicic rocks.

Fig. 27. Summary of different tectonic settings of the igneous construction of oceanic crust / ophiolites and the related processes. Data in panels A, B and C are from the following sources: A1: Saccani et al. (2015); A2: Zeng et al. (2015); A3: Xu et al. (2004); B (general): Haase et al. (2015); Palin and White (2016); for element transport, mantle hydration and melting during subduction: Tatsumi and Kogiso (1997); Grove et al. 2006; for the metamorphic transition in the subducted slab: Tatsumi and Kogiso (1997), Schmidt and Poli (1998), Angiboust et al. (2014), Bebout and Penniston-Dorland (2016); C1: Hildreth (1981), Watanabe et al. (2006); C2: Grimes et al. (2013), France et al. (2010), C3: Martin (1999). Abbreviations: BABB - Back-arc basin basalt; CC - Continental crust: LS - Lithosphere; OLS - Oceanic lithosphere; AS - Asthenosphere; OC - Oceanic crust; L - Lava; Dk - Dike; Gb - Gabbro; Isot - Isotropic gabbro; DM - Depleted mantle; EM Enriched mantle; Cum - Cumulate; Um - Ultramafic rocks; Gr.sch - Greenschist; Amph Amphibolite; Ecl - Eclogite; Intm - Intermediate; EM - enriched mantle; DM - depleted mantle; MDM - multiply depleted mantle; BABB - backarc basin basalt.

Table 1. Summary of ophiolite complexes. Full references are provided in Supplementary File-1.

Abbreviations: Column A: East Pacific Rise: EPR; East Scotia Ridge: ESR; Izu-Bonin-Mariana: IBM; Kyushi-Palau Ridge: K-PR; Manus Spreading Centre: MSC; Melange: Mel. Column B: California: Cal. Column C: Cambrian: Camb., Ordovician: Ord., Permian: Perm., Triassic: Trias., Jurassic: Jur., Cretaceous: Cret. Column D: Albite granite: Alb.gr.; Andesite: And.; Basaltic andesite: Bas. and.; Dacite: Dac.; Dike: Dk.; Diorite: Di.; Diorite porphyry: Di.porph.; Felsic: Fel.; Granodiorite: Gr.di.; Granite: Gr.; Granophyre: Gr.phy.; Hornblende-plagioclase 
1780 porphyry: Hbl-pl.porph.; Icelandite: Isl.di.; Intermediate: interm.; Keratophyre: Ker.;

1781 Leucodiorite: Leucodi.; Leucogranite: Leucogr.; Monzogranite: Mon.gr.; Plagiogranite: Pl.gr.;

1782 Quartz diorite: Quartz monzodiorite: Q-mon.di.; Q-di.; Quartz porphyry: Q-porph.; Rhyodacite:

1783 Rhy.dac.; Rhyolite: Rhy.; Tonalite: Ton.; Trachydacite: Try.dac.; Trondhjemite: Tr.hj.ite.;

1784 Volcanics: Volc. Column F: Shafaii Moghadam: Sh.Mogh.; Van Kranendonk \& Pirajno: Van Kr.

1785 \& Pir. Column G: Lithosphere: Li.sph.; Mantle plume: MP; Marginal basin: Marg.bas.; Oceanic:

1786 Oc.; Seafloor spreading: Sfs.; Subducted: Subd.; Suprasubduction zone: SSZ. Column H:

1787 Rift/Continental Margin: R/CM; Mid-ocean-ridge: MORB; Plume/MOR: P/MOR; Backarc: BA;

1788 Backarc to Forearc: BA-FA; Forearc: FA; Volcanic Arc: VA. In italics: ophiolite type suggested 1789 from literature.

1790

1791 Table 2. Summary of geochemical proxies for the classification of ophiolite types. 


\section{ABSTRACT}

We present a global synthesis of the geochemistry of intermediate to silicic intrusive and volcanic rocks from 149 Phanerozoic to Archean ophiolites, and evaluate models for their genesis during the development of oceanic crust in different tectonic environments. Our synthesis shows that the evolved rocks in subduction-unrelated, Rift/Continental Margin ophiolites are predominantly basaltic andesite and andesite, whereas MOR type (mid-ocean ridge) ophiolites exhibit nearly equal proportions of basaltic andesite/andesite and rhyodacite and Plume/MOR type ophiolites are characterized by rhyolites. Intermediate to silicic volcanic units in the Backarc sub-group of subduction-related ophiolites are characterized by similar amounts of basaltic andesite/andesite and rhyodacite, whereas in the Backarc to Forearc, Forearc, and Volcanic Arc sub-groups they are mainly basaltic andesite/andesite. The $\mathrm{Zr}$, Nb and La contents of the intermediate to silicic rocks in subduction-related ophiolites are significantly lower than those of their counterparts in subduction-unrelated ophiolites. Intermediate to silicic rocks in Rift/Continental Margin and Plume/MOR type ophiolites are generally LREE-enriched, whereas those in the MOR type vary from LREE-depleted to LREE-enriched. The Backarc and Backarc to Forearc types are similar to the MOR type; silicic rocks of the Forearc and Volcanic Arc types are generally LREE-enriched. $\mathrm{Nb}, \mathrm{Sr}, \mathrm{Eu}$, and $\mathrm{Ti}$ exhibit negative anomalies of varying magnitudes in multi-element diagrams. Our modeling based on the $\mathrm{La}_{-} \mathrm{SiO}_{2}$ proxies of Brophy (2009) suggests that the main process in the formation of the majority of the intermediate to silicic rocks in both subduction-unrelated and subduction-related ophiolites is partial melting of basaltic and/or gabbroic rocks beneath the spreading centers, whereas a minor volume in subduction-related ophiolites are adakites that resulted from partial melting of the subducting slab. Silicic to intermediate rocks in Plume/MOR type ophiolites appear to be generated by fractional crystallization of basaltic melt. The incompatible, non-conservative elements, such as $\mathrm{Ba}$ and $\mathrm{Th}$, are weakly to strongly enriched in subduction-related ophiolites as a result of shallow to deep enrichment associated with subduction zone processes. 
Table 1. Summary of ophiolitic sequences, their felsic rock types and suggested tectonic enviromnment and ophiolite types

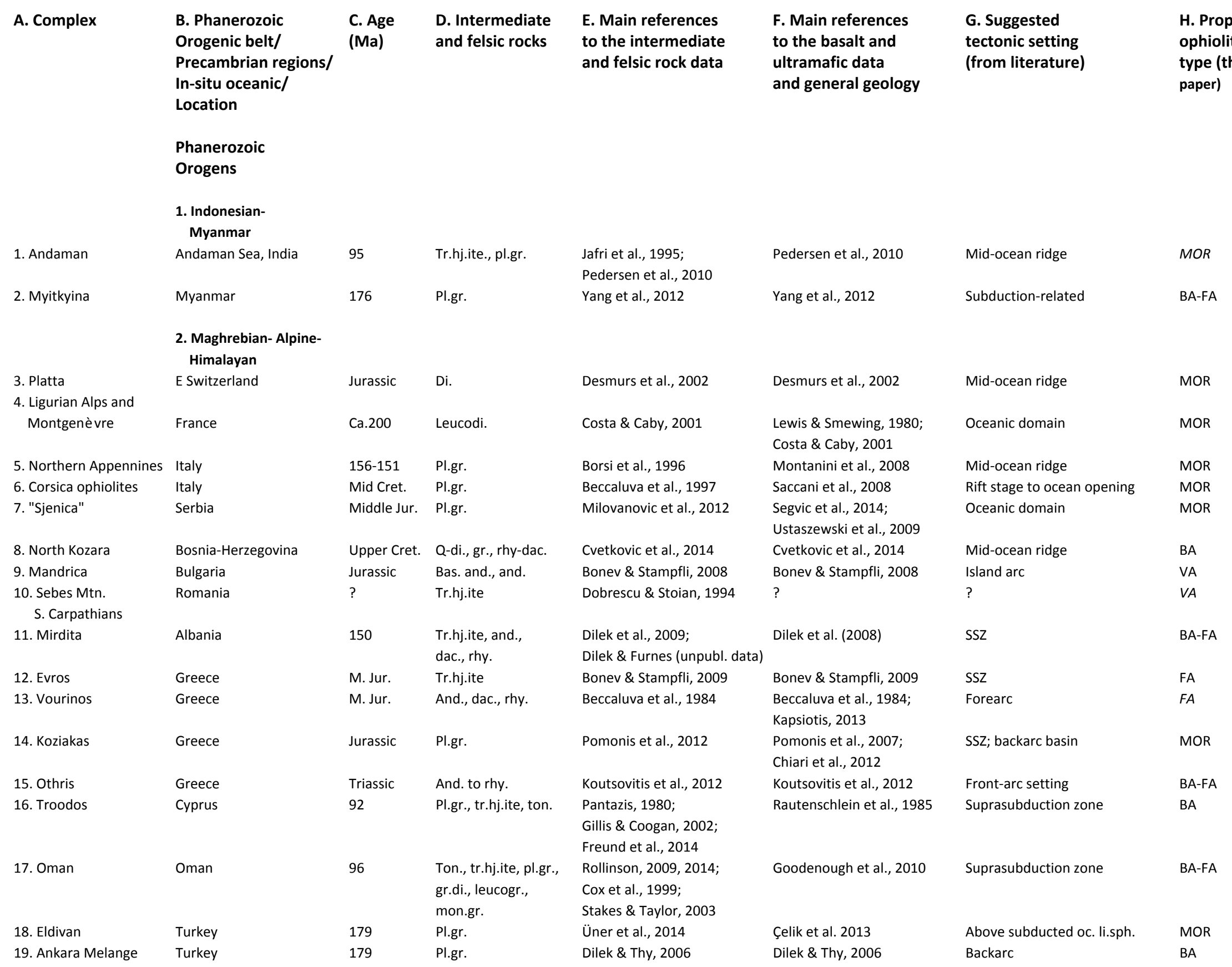
olite pe (this paper)

BA-FA

MOR

A

A-FA

MOR

A-FA

A-FA 
Table 1. Summary of ophiolitic sequences, their felsic rock types and suggested tectonic enviromnment and ophiolite types

\begin{tabular}{|c|c|c|c|c|c|c|c|}
\hline 20. Sarikaraman & Turkey & ca. 92 & Pl.gr., tr.hj.ite, rhy. & $\begin{array}{l}\text { Floyd et al., 1998; } \\
\text { Yaliniz et al., } 2000\end{array}$ & Yaliniz et al. 1996 & SSZ & BA \\
\hline 21. Kizildag & Turkey & ca. 92 & Pl.gr. & Karaoğlan et al., 2013 & Dilek \& Thy, 2009 & SSZ & BA \\
\hline 22. Guleman & Turkey & ca. 92 & Pl.gr. & Kiliç, 2009 & Kiliç, 2009, 2012 & SSZ & BA-FA \\
\hline 23. Sabsevar & Iran & $100-78$ & Pl.gr. & Sh. Mogh. et al., 2014 & Sh. Mogh. et al., 2014 & Mid-ocean ridge & BA \\
\hline 24. Neyriz & Iran & $96-82$ & Pl.gr., rhy.dac. & Babaie et al., 2006 & Babaie et al., 2006 & SSZ & BA \\
\hline $\begin{array}{l}\text { 25. Band-e-Zeyarat/ } \\
\text { Dar Anar }\end{array}$ & Iran & $142-141$ & Tr.hj.ite & Ghazi et al., 2004 & Ghazi et al., 2004 & Mid-ocean ridge & BA \\
\hline 26. Haji-Abad & Iran & Late Cret. & $\begin{array}{l}\text { And., dac., rhy., } \\
\text { ton., pl.gr. }\end{array}$ & Sh. Mogh. et al., 2013a & Sh. Mogh. et al., 2013a & Forearc & BA-FA \\
\hline 27. Gogher-Baft & Iran & Late Cret. & Felsic volcanics & Sh. Mogh. et al., 2013b & Sh. Mogh. et al., 2013b & Subduction initiation setting & BA-FA \\
\hline 28. Dehshir & Iran & Late Cret. & Dac., gr. & Sh. Mogh. et al., 2010 & Sh. Mogh. et al., 2010 & SSZ & BA \\
\hline 29. Mawat & NE Iraq & ca. 100 & Pl.gr. & Mirza \& Ismail, 2007 & Mirza, 2008; Azizi et al., 2013 & Oceanic crust & MOR \\
\hline $\begin{array}{l}\text { 30. Mingora ophiolitic } \\
\text { melange }\end{array}$ & Pakistan & $\begin{array}{l}\text { Mid. Jur - } \\
\text { Early Cret. }\end{array}$ & Pl.gr. & Barbieri et al., 1994 & Barbieri et al., 1994 & $?$ & MOR \\
\hline 31. Waziristan & NW Pakistan & $\begin{array}{l}\text { Late Jur.- } \\
\text { Early Cret. }\end{array}$ & Tr.hj.ite & Khan et al., 2003 & Khan et al., 2007 & Island arc/mid-ocean ridge & $B A$ \\
\hline 32. Muslim Bagh & NW Pakistan & Trias. - Cret. & Pl.gr. & Kakar et al., 2014 & Kakar et al., 2014 & Island arc/mid-ocean ridge & BA \\
\hline \multicolumn{8}{|l|}{ Yarlung-Zangbo } \\
\hline 33. Dras & India & ca. 135 & And. & Clift et al., 2002 & Clift et al., 2002 & Intraoceanic arc & VA \\
\hline 34. Nidar & India & $130-110$ & Pl.gr. & Rao et al., 2004 & Mahé o et al., 2004 & Intraoceanic arc & BA \\
\hline 35. Spontang & India & $130-110$ & Di., and. & Pedersen et al., 2001 & Mahéo et al., 2004 & Intraoceanic arc & BA \\
\hline 36. Sangsang & Tibet & $155-130$ & Felsic lava & Bedard et al., 2009 & Bedard et al., 2009 & Backarc-arc & BA \\
\hline 37. Jinlu & Tibet & 125 & Bas. and. & Dubois-Cote et al., 2005 & Dubois-Cote et al., 2005 & Intraoceanic arc & BA-FA \\
\hline \multirow[t]{2}{*}{ 38. Xigaze } & Tibet & $130-120$ & Q-di. & Dai et al., 2013 & Dai et al., 2013 & Suprasubduction zone & BA \\
\hline & 3. Caribbean Region & & & & & & \\
\hline 39. Mayari-Baracoa & Eastern Cuba & Cret. & And., dac. & Marchesi et al., 2007 & $\begin{array}{l}\text { Frei et al., 2006; } \\
\text { Marchesi et al., } 2007\end{array}$ & $\begin{array}{l}\text { Backarc spreading } \\
\text { to front arc }\end{array}$ & BA-FA \\
\hline 40. Aruba Lava Fm & Dutch Caribbean & $85-82$ & Ton., hbl-pl. porph., gr. & White et al., 1999 & White et al., 1999 & MORB & MOR \\
\hline 41. Nicoya & Costa Rica, Caribbean & $95-86$ & Pl.gr. & Wildberg, 1987 & Hauff et al., 2000 & Oceanic plateau & MOR \\
\hline 42. Central Hispaniola & Caribbean & 115 & Dac., rhy. & Escuder Viruete et al., 2008 & Escuder Viruete et al., 2008 & Subduction initiation & BA \\
\hline \multirow[t]{2}{*}{ 43. Puerto Plata } & Dominican Republic & 126 & Bas. and., and., dac. & Escuder Viruete et al., 2014 & Escuder Viruete et al., 2014 & Island arc/backarc system & BA \\
\hline & $\begin{array}{l}\text { 4. Cordilleran and } \\
\text { Western Pacific }\end{array}$ & & & & & & \\
\hline 44. Elder Creek & California, USA & Mid-Jur. & Tr.hj.ite, ton., di., q-di. & Shervais, 2008 & Shervais, 2008 & SSZ & $B A$ \\
\hline 45. Ingalls & California, USA & Mid-Late Jur. & Tr.hj.ite, ton. & MacDonald et al., 2008 & MacDonald et al., 2008 & SSZ & BA \\
\hline 46. Smartville & California, USA & Late Jur. & Ton., gr.di. & Beard, 1998 & Beard, 1998 & Arc magmatism & BA-FA \\
\hline 47. Josephine & Cal.-Oregon, USA & 165 & Pl.gr. & Harper, 2003 & Harper, 2003 & SSZ & BA \\
\hline 48. Canyon Mtn. & Oregon, USA & Early Perm. & $\begin{array}{l}\text { Di., ton., tr.hj.ite., } \\
\text { alb.gr. }\end{array}$ & Gerlach et al., 1981a, b & Gerlach et al., 1981a, b & Arc magmatism & $V A$ \\
\hline 49. Fidalgo Island & Washington State, USA & Jurassic & Tr.hj.ite., ker., alb-gr. & Brown et al., 1979 & Brown et al., 1979 & Ocean floor & $M O R$ \\
\hline 50. Ganychalan terrane & NE Russia & Paleozoic & Ton., pl.gr. & Sokolov et al., 2003 & Sokolov et al., 2003 & SSZ & BA-FA \\
\hline
\end{tabular}


Table 1. Summary of ophiolitic sequences, their felsic rock types and suggested tectonic enviromnment and ophiolite types

\begin{tabular}{|c|c|c|c|c|c|c|c|}
\hline 51. Main melange zone & NE Russia & Early Mes. & Pl.gr. & Sokolov et al., 2003 & Sokolov et al. 2003 & Arc system & $V A$ \\
\hline $\begin{array}{l}\text { 52. Pekulney Ridge } \\
\text { island arc }\end{array}$ & NE Russia & L.Jur-E. Cret. & Pl.gr., ton. & Luchitskaya et al., 2005 & Luchitskaya et al. 2005 & SSZ & $F A$ \\
\hline 53. E. Kamchatka oph. & Russia & Upper Cret. & Pl.gr. & Tsukanov et al., 2007 & Tsukanov et al., 2007 & Volcanic arc & BA-FA \\
\hline 54. Yakuno & Japan & 280 & $\begin{array}{l}\text { Ton., q-di., gr.di., and., } \\
\text { rhy., gr., q-mon.di. }\end{array}$ & $\begin{array}{l}\text { Ishiwatari et al., 1990; } \\
\text { Suda, } 2004\end{array}$ & $\begin{array}{l}\text { Ichiyama and } \\
\text { Ishiwatari, } 2004\end{array}$ & Backarc basin & VA \\
\hline 55. Horokanai & Japan & Late Jur. & And. & Takashima et al., 2002 & Takashima et al., 2002 & Marginal sea above SSZ & BA \\
\hline 56. Mineoka & Japan & 66 & Di. & Hirano et al., 2003 & Hirano et al., 2003 & Subduction and within-plate & BA \\
\hline 57. Darvel Bay & Malaysia & са. 140 & Pl.gr. & Omang \& Barber, 1996 & Omang \& Barber, 1996 & Suprasubduction zone & $B A$ \\
\hline 58. Cyclops & New Guinea Isl. & 43.2 & And., dac. & Monnier et al., 1999 & Monnier et al., 1999 & Forearc to backarc & BA-FA \\
\hline 59. New Caledonia & New Caledonia & $\begin{array}{l}\text { Late Cret. - } \\
\text { Early Eocene }\end{array}$ & $\begin{array}{l}\text { Felsic volc., pl.gr., gr., } \\
\text { and., dac., leucodi. }\end{array}$ & $\begin{array}{l}\text { Cameron, 1989; } \\
\text { Meffre et al., 1996; } \\
\text { Cluzel et al., } 2006\end{array}$ & Ulrich et al., 2010 & Backarc basin & $B A$ \\
\hline 60. Dun Mtn. & New Zealand & 280 & Pl.gr. & Sano et al., 1997 & Sano et al., 1997 & Backarc basin & $B A$ \\
\hline \multirow[t]{2}{*}{ 61. Northland } & New Zealand & ca. 30 & Pl.gr., and. & $\begin{array}{l}\text { Thompson et al., 1997; } \\
\text { Whattam et al., 2005, } 2006\end{array}$ & $\begin{array}{l}\text { Thompson et al., 1997; } \\
\text { Whattam et al., } 2006\end{array}$ & Backarc basin & BA \\
\hline & 5. Hercynian/Variscan & & & & & & \\
\hline 62. Kaczawa & Poland & Lw.Pal. & Trachyte, rhy.dac. & Furnes et al., 1994 & Furnes et al., 1994 & Rift type & Rift/CM \\
\hline 63. Beja-Acebuches & SE Portugal & 350 & Leucodi., felsic rocks & Pin et al., 2008 & Pin et al., 2008 & $\begin{array}{l}\text { Slab break-off that } \\
\text { followed subduction }\end{array}$ & MOR \\
\hline 64. Morais (group II) & North Portugal & 405 & Felsic rocks & Pin et al., 2006 & Pin et al., 2006 & Introceanic subduction & BA \\
\hline \multirow[t]{2}{*}{ 65. Chamrousse } & France & 496 & Pl,gr., ton., ker. & $\begin{array}{l}\text { Ménot et al., 1988; } \\
\text { Ménot, } 1987\end{array}$ & $\begin{array}{l}\text { Bodinier et al., 1981; } \\
\text { Ménot, } 1987\end{array}$ & Mid-ocean ridge & MOR \\
\hline & 6. Uralian & & & & & & \\
\hline 66. Magnitogorsk & Russia & $400-385$ & And., dac. & Spadea \& Scarrow, 2000 & Spadea \& Scarrow, 2000 & Forearc region & BA-FA \\
\hline \multirow[t]{2}{*}{ 67. Nurali } & Russia & $468-483$ & $\begin{array}{l}\text { And., dac., gr.di., } \\
\text { ton., gr. }\end{array}$ & Gaggero et al., 1997 & Gaggero et al., 1997 & $\begin{array}{l}\text { Intraoceanic arc/ } \\
\text { continental margin }\end{array}$ & $V A$ \\
\hline & 7. Central Asian & & & & & & \\
\hline 68. Dananhu island arc & NW China & $360-320$ & Pl.gr., and., q-porph. & Zhang et al., 2006 & Zhang et al., 2006 & Island arc & $V A$ \\
\hline $\begin{array}{l}\text { 69. Kekesentao- } \\
\text { Qiaoxiahala-Kuerti }\end{array}$ & NW China & 372 & Pl.gr. & Zhang et al., 2003 & Wang et al., 2012a, b & Mid-ocean ridge/SSZ & BA \\
\hline 70. Tangbale & NW China & Middle Ord. & Felsic volc. & Buckman \& Aitchison, 2004 & $\begin{array}{l}\text { Chi et al., 1993; } \\
\text { Buckman \& Aitchison, } 2004\end{array}$ & Intra-oceanic setting & BA \\
\hline 71. Zhaheba & NW China & $495-422$ & Pl. gr., di.porph. & $\begin{array}{l}\text { Luo et al., 2015; } \\
\text { Zeng et al., } 2015\end{array}$ & Luo et al., 2015 & Oceanic island arc & BA-FA \\
\hline 72. Chagantaolegai & NW China & 518 & And. & Zhao \& He, 2014 & Zhao \& He, 2014 & Mid-ocean ridge & MOR \\
\hline $\begin{array}{l}\text { 73. Yueyashan- } \\
\text { Xichangjing } \\
\text { (Beishan Collage) }\end{array}$ & NW China & 533 & Pl.gr., ton., and., dac. & Ao et al., 2012 & Ao et al., 2012 & Subduction-related & BA \\
\hline 74. Solonker & China and Mongolia & Permian & Ton., and., dac., rhy. & Jian et al., $2010 \mathrm{~b}$ & Jian et al., 2010b & Arc-trench system & BA-FA \\
\hline 75. Manlay & South Mongolia & $509-482$ & And., dac. & Zhu et al., 2014 & Zhu et al., 2014 & SSZ to island arc & BA-FA \\
\hline 76. Agardagh Tes-Chem & Mongolia & 569 & And., dac. & Pfänder et al., 2002 & Pfänder et al., 2002 & Intra-oceanic island arc system & BA \\
\hline
\end{tabular}


Table 1. Summary of ophiolitic sequences, their felsic rock types and suggested tectonic enviromnment and ophiolite types

\begin{tabular}{|c|c|c|c|c|c|c|c|}
\hline & & & & & & and associated backarc basin & \\
\hline 77. Bayannur & Western Mongolia & 572 & Ton., tr.hj.ite & Kovalenko et al., 2014 & $\begin{array}{l}\text { Dijkstra et al., 2006; } \\
\text { Kovalenko et al., } 2014\end{array}$ & SSZ & BA-FA \\
\hline \multirow[t]{2}{*}{ 78. Bayankhongor } & Central Mongolia & 636 & Pl.gr. & Jian et al., 2010a & Jian et al., 2010a & Mid-ocean ridge & MOR \\
\hline & 8. Qingling-Qilian-K & & & & & & \\
\hline \multicolumn{8}{|l|}{ Jinshajiang oph. Mel. } \\
\hline 79. Jiyidu & SW China & 283 & Ton. & Zi et al., 2012 & Jian et al., 2009 & Subduction setting & $B A$ \\
\hline 80. Dongzhulin & SW China & 347 & Tr.hj.ite & Zi et al., 2012 & Jian et al., 2009 & Rift setting & $\mathrm{Rift} / \mathrm{CM}$ \\
\hline 81. Oytag & NW China & $338-328$ & Tr.hj.ite., ton. & Jiang et al., 2008 & Jiang et al., 2008 & Island arc & BA \\
\hline \multirow[t]{3}{*}{ 82. Shangdan } & East China & 517 & Dac. & Dong et al., 2011 & Dong et al., 2011 & Backarc basin & BA-FA \\
\hline & 9. Bangong-Nujian & & & & & & \\
\hline & Suture & & & & & & \\
\hline $\begin{array}{l}\text { 83. Changning- } \\
\text { Menglian (Gicha) }\end{array}$ & SW China & $311-277$ & Ton. & Jian et al., 2009 & Jian et al., 2009 & Mid-ocean ridge & BA \\
\hline $\begin{array}{l}\text { 84. Changning- } \\
\text { Menglian(Banpo) }\end{array}$ & SW China & $288-284$ & Ton. & Jian et al., 2009 & Jian et al., 2009 & Mid-ocean ridge & BA \\
\hline 85. Qiantang & North Tibet & 356 & Pl.gr. & Zhai et al., 2013 & Zhai et al., 2013 & Mid-ocean ridge & MOR \\
\hline 86. Ailaochan & SW China & $387-374$ & Pl.gr. & Jian et al., 2009 & Jian et al., 2009 & Mid-ocean ridge & MOR \\
\hline \multirow[t]{2}{*}{ 87. W Gagma Co } & Tibet & $501-437$ & Pl.gr. & Zhai et al., 2016 & Zhai et al., 2016 & SSZ & MOR \\
\hline & 10. Andean & & & & & & \\
\hline 88. Sarmiento & Chile & 150 & Tr.hj.ite, gr.phy., pl.gr. & Saunders et al., 1979 & Saunders et al., 1979 & Marginal basin & BA \\
\hline \multirow[t]{2}{*}{$\begin{array}{l}\text { 89. Famatinian } \\
\text { magmatic arc }\end{array}$} & Argentina & $\begin{array}{l}\text { Late Camb. - } \\
\text { Middle Ord. }\end{array}$ & $\begin{array}{l}\text { Leucogr., leucoton., } \\
\text { ton. }\end{array}$ & Otamendi et al., 2009 & Otamendi et al., 2009 & Magmatic arc & VA \\
\hline & 11. Appalachian & & & & & & \\
\hline $\begin{array}{l}\text { 90. Tyrone Ign. } \\
\text { Complex }\end{array}$ & Ireland & $490-475$ & $\begin{array}{l}\text { Ton., pl.gr., and., } \\
\text { dac., rhy. }\end{array}$ & $\begin{array}{l}\text { Draut et al., 2009; } \\
\text { Hollis et al., 2013; }\end{array}$ & $\begin{array}{l}\text { Draut et al., 2009; } \\
\text { Hollis et al., } 2013\end{array}$ & SSZ & BA-FA \\
\hline 91. Fournier & Quebec, Canada & 461 & PI.gr. & $\begin{array}{l}\text { Spray et al., 1990; } \\
\text { Brophy \& Pu, 2012; } \\
\text { Flagler \& Spray, } 1991\end{array}$ & Brophy \& Pu, 2012 & Mid-ocean ridge & BA \\
\hline 92. Thetford Mines & Quebec, Canada & 470 & Pl.gr. & $\begin{array}{l}\text { Olive et al., 1997; } \\
\text { Whitehead et al., } 2000\end{array}$ & $\begin{array}{l}\text { Olive et al., 1997; } \\
\text { Page et al., } 2009\end{array}$ & Spreading in forearc & BA-FA \\
\hline 93. Boil Mountain & Maine, USA & 477 & Ton. & Van Vleck \& Beane, 2001 & $\begin{array}{l}\text { Kusky et al., 1997; } \\
\text { Van Vleck \& Beane, } 2001\end{array}$ & backarc & $B A-F A$ \\
\hline 94. Annieopsquotch & Newfoundland & 480 & Tr.hj.ite, fel. dk, tuff & Cutts et al., 2012 & Lissenberg et al., 2005 & SSZ - backarc & BA \\
\hline 95. Lac Brompton & Quebec, Canada & 480 & Q-di., pl.gr. & De Souza et al., 2008 & De Souza et al., 2008 & Forearc seafloor & FA \\
\hline 96. Bay of Islands & Newfoundland & 485 & Tr.hj.ite. & $\begin{array}{l}\text { Malpas, 1979; } \\
\text { Jenner et al., } 1991\end{array}$ & Kurth-Velz et al., 2004 & Marginal basin - arc & BA-FA \\
\hline 97. Betts Cove & Newfoundland & 488 & Dac., rhy. & Bédard et al., 2000 & Bédard, 1999 & SSZ & FA \\
\hline 98. Little Port & Newfoundland & 505 & Tr.hj.ite. & $\begin{array}{l}\text { Malpas, 1979; } \\
\text { Jenner et al., } 1991\end{array}$ & $\begin{array}{l}\text { Malpas, 1979; } \\
\text { Jenner et al., } 1991\end{array}$ & Backarc-related & BA \\
\hline
\end{tabular}


Table 1. Summary of ophiolitic sequences, their felsic rock types and suggested tectonic enviromnment and ophiolite types

\begin{tabular}{|c|c|c|c|c|c|c|c|}
\hline \multirow[b]{2}{*}{ 99. Lyngen } & \multicolumn{7}{|l|}{ 12. Caledonides } \\
\hline & North Norway & c. 480 & Ton. & Selbekk et al., 1998 & $\begin{array}{l}\text { Kvassnes et al. 2004; } \\
\text { H.Furnes (unpubl. data) }\end{array}$ & Incipient oceanic arc & VA \\
\hline 100. Leka & Central Norway & 497 & Pl.gr. & Furnes et al., 1992 & Furnes et al., 1992 & Introceanic subduction & BA-FA \\
\hline 101. Trondheim area & Central Norway & $493-481$ & Pl.gr., tr.hj.ite & Grenne, 1989; Slagstad, 2003 & Grenne, 1989; Slagstad, 2003 & Island arc/backarc & BA \\
\hline 102. Karmøy & Western Norway & $497-470$ & Pl.gr. & Pedersen \& Malpas, 1984 & Pedersen \& Hertogen, 1990 & Island arc/arc basin & BA-FA \\
\hline \multirow[t]{2}{*}{$\begin{array}{l}\text { 103. Solund- } \\
\text { Stavfjord }\end{array}$} & Western Norway & 443 & Pl.gr. & $\begin{array}{l}\text { Skjerlie, 1992; } \\
\text { Furnes (unpubl. data) }\end{array}$ & $\begin{array}{l}\text { Furnes et al., 1990, } \\
\text { 2006, 2012b }\end{array}$ & Backarc basin & BA \\
\hline & 13. Tasmanide & & & & & & \\
\hline \multirow[t]{3}{*}{ 104. Weraerai terrane } & SE Australia & 530 & Pl.gr. & Aitchison \& Ireland, 1995 & Aitchison \& Ireland, 1995 & SSZ & $B A$ \\
\hline & $\begin{array}{l}\text { Precambrian } \\
\text { regions }\end{array}$ & & & & & & \\
\hline & 14. Cadomian & & & & & & \\
\hline \multirow[t]{2}{*}{ 105. Frolosh/Struma } & Bulgaria & 560 & Interm. to fel. rocks & Kounov et al., 2012 & Kounov et al., 2012 & Magmatic arc & BA \\
\hline & $\begin{array}{l}\text { 15. Arabian-Nubian } \\
\text { Shield }\end{array}$ & & & & & & \\
\hline 106. Janbu & Saudi Arabia & 789 & And. & Ahmed \& Hariri, 2008 & Ahmed \& Hariri, 2008 & Small ocean basin & VA \\
\hline 107. Darb Zubaydah & Saudi Arabia & 830 & And., rhy. & Quick, 1990 & Quick, 1990 & Intra-arc rifting & $B A$ \\
\hline 108. Wadi Ghadir & Egypt & 750 & Interm. volc. rocks & Abd El-Rahman et al., 2009a & $\begin{array}{l}\text { Abd El-Rahman et al., 2009a; } \\
\text { Basta et al., } 2011\end{array}$ & backarc basin & BA \\
\hline 109. Wadi Kareim & Egypt & 750 & Felsic volc. rocks & Ali et al., 2009 & Ali et al., 2009 & backarc basin & BA \\
\hline 110. Wadi El Dabbah & Egypt & 750 & Felsic volc. rocks & Ali et al., 2009 & Ali et al., 2009 & Volcanic arc & VA \\
\hline \multirow[t]{2}{*}{ 111. Fawakhir } & Egypt & $800-700$ & Interm. volc. rocks & Abd El-Rahman et al., 2009b & Abd El-Rahman et al., 2009b & $\begin{array}{l}\text { Intra-oceanic SSZ, } \\
\text { (incipient arc-forearc) }\end{array}$ & BA \\
\hline & 16. India & & & & & & \\
\hline 112. Manamendu & India & 800 & Pl.gr. & Yellappa et al., 2010 & Yellappa et al., 2010 & SSZ & FA \\
\hline 113. Kolar & $\begin{array}{l}\text { India } \\
\text { (Dharwar Craton) }\end{array}$ & 2550 & Fel. Volc. & $\begin{array}{l}\text { Chardon et al., 2002; } \\
\text { Ugarkar et al., } 2013\end{array}$ & Rajamani et al., 1985 & Island arc & $V A$ \\
\hline 114. Hutti & India & 2600 & Mg-And., adakite & Manikyamba et al., 2009 & Manikyamba et al., 2009 & Intraoceanic subduction & BA-FA \\
\hline $\begin{array}{l}\text { 115. Kushtagi- } \\
\text { Hungund }\end{array}$ & Southern India & 2746 & Adakite & Naqvi et al., 2006 & Naqvi et al., 2006 & $\begin{array}{l}\text { Plume-fed oceanic slab, subd. } \\
\text { in intraoceanic setting }\end{array}$ & BA-FA \\
\hline \multicolumn{8}{|l|}{ Ore Group } \\
\hline & 17. Baltica and Siberia & & & & & & \\
\hline 117. Enganepe & Polar Urals, Russia & 670 & Adakite & Scarrow et al., 2001 & Scarrow et al., 2001 & Oceanic island arc & BA-FA \\
\hline 118. Jormua & Baltica, Finland & 1950 & Tr.hj.ite & Kontinen, 1987 & Peltonen et al., 1996 & Red Sea type & Rift/CM \\
\hline 119. Pilgujärvi & Pechenga, Kola, Russia & 1970 & Rhy. & Skruf'in \& Theart, 2005 & Skruf'in \& Theart, 2005 & Red Sea type & Rift/CM \\
\hline 120. Kholodnikan & Siberia, Russia & 2410 & And., dac., rhy. & Lavrik \& Miskin, 2010 & Lavrik \& Miskin, 2010 & Mantle plume & $P / M O R$ \\
\hline 121. Avarench & Kola, Russia & 2429 & And., dac., rhy. & Vrevsky, 2011 & Vrevsky, 2011 & Intracratonic rifting & Rift/CM \\
\hline 122. Suomussalmi & Baltica, Finland & 2650 & Interm. - fel. volc. & Jahn et al., 1980 & Jahn et al., 1980 & No suggestion & $B A$ \\
\hline
\end{tabular}


Table 1. Summary of ophiolitic sequences, their felsic rock types and suggested tectonic enviromnment and ophiolite types

\begin{tabular}{|c|c|c|c|c|c|c|c|}
\hline \multirow{3}{*}{$\begin{array}{l}\text { 123. Tikshozero } \\
\text { 124. Khizovaara - } \\
\text { Iringora }\end{array}$} & Karelia, Russia & 2785 & Interm. - fel. volc. & Mil'kevich et al., 2007 & Mil'kevich et al., 2007 & Backarc and initial back arc & BA-FA \\
\hline & Karelia, Russia & 2800 & Interm. - fel. volc. & Shchipansky et al., 2004 & Shchipansky et al., 2004 & SSZ & BA-FA \\
\hline & 18. Australia & & & & & & \\
\hline $\begin{array}{l}\text { 125. Gindalbie \& } \\
\text { Kurnalpi }\end{array}$ & SW Australia & 2700 & And., dac., rhy. & Barley et al., 2008 & Barley et al., 2008 & Intra-arc to mature arc-rift & VA \\
\hline $\begin{array}{l}\text { 126. Meekatharra- } \\
\text { Cue }\end{array}$ & SW Australia & $2800-2760$ & And., fel. vol. & Wyman \& Kerrich, 2012 & Wyman \& Kerrich, 2012 & $\begin{array}{l}\text { Subduction-related magm. } \\
\text { from depleted plume }\end{array}$ & BA-FA \\
\hline $\begin{array}{l}\text { 127. Whundo Group } \\
\text { Pilbara Supergroup }\end{array}$ & NW Australia & 3120 & And., dac., rhy. & Smithies et al., 2005 & Smithies et al., 2005 & Intracoeanic arc setting & BA-FA \\
\hline $\begin{array}{l}\text { 128. Kelly Group } \\
\text { 129. Warrawoona } \\
\text { Group }\end{array}$ & $\begin{array}{l}\text { NW Australia } \\
\text { NW Australia }\end{array}$ & $\begin{array}{l}3350-3290 \\
3530-3430\end{array}$ & $\begin{array}{l}\text { Rhy. } \\
\text { And., dac., rhy. }\end{array}$ & $\begin{array}{l}\text { Jahn et al., } 1981 \\
\text { Smithies et al., } 2007\end{array}$ & $\begin{array}{l}\text { Van Krd. \& Pir., } 2004 \\
\text { Van Krd. \& Pir., 2004; } \\
\text { Smithies et al., } 2007\end{array}$ & $\begin{array}{l}\text { Plume mamatism } \\
\text { Plume magmatism }\end{array}$ & $\begin{array}{l}\text { FA } \\
\text { BA-FA }\end{array}$ \\
\hline & 19. China & & & & & & \\
\hline 130. Anhui \& Jiangxi & South China & 970 & Pl.gr. & $\begin{array}{l}\text { Li \& Li, 2003; } \\
\text { Gao et al., } 2009\end{array}$ & Zhou, 1989; Li et al., 1997 & $\begin{array}{l}\text { Anhui: Oc. crust in marg. bas. } \\
\text { Jiangxi: Oc. crust in } \\
\text { interarc bas. }\end{array}$ & BA \\
\hline 131. Miowan & $\begin{array}{l}\text { South China } \\
\text { (Yangtze Craton) } \\
\text { 20. North America/ } \\
\text { Canada }\end{array}$ & 1000 & Tr.hj.ite & Peng et al., 2012 & Peng et al., 2012 & Arc/forearc & BA \\
\hline 132. Burin Group & Newfoundland & 760 & Fel. rocks & Murphy et al., 2008 & Murphy et al., 2008 & Oceanic setting, ensim. arc & VA \\
\hline 133. Payson & Central Arizona & 1730 & Dac., ton. & Dann, 1992 & Dann, 1992 & Intra-arc basin, sfs & BA \\
\hline 134. Elu Link & North Canada & $2716-2663$ & Fel. volc. & Mvondo et al., 2013 & Mvondo et al., 2013 & Backarc & BA \\
\hline 135. Abitibi & SE Canada & $2735-2670$ & Fel. volc. & Gaboury \& Pearson, 2008 & $\begin{array}{l}\text { Xie et al., 1993; Wyman, 1999; } \\
\text { Kerrich et al., 1998; } \\
\text { Sprole et al., 2002; } \\
\text { Mueller et al., 2009; } \\
\text { Dostal \& Mueller, } 2013\end{array}$ & $\begin{array}{l}\text { Oceanic arc and } \\
\text { plume magmatism }\end{array}$ & BA \\
\hline 136. Yellowknife & NW Canada & $2720-2670$ & Fel. Tuff & Cousens, 2000 & Cousens, 2000 & Backarc & VA \\
\hline 137. Wawa & $\begin{array}{l}\text { Canada } \\
\text { 21. South America }\end{array}$ & $2750-2650$ & Fel. volc. \& dk. & Polat \& Kerrich, 2000 & Polat \& Kerrich, 2000 & Island arc & VA \\
\hline $\begin{array}{l}\text { 138. Mazaruni \& } \\
\text { Barama }\end{array}$ & North Guyana, Brazil & 2250 & Fel. rocks & Renner \& Gibbs, 1987 & Renner \& Gibbs, 1987 & Incipient arc or marg. bas. & $B A$ \\
\hline 139. Rio das Velhas & SE Brazil & 2772 & Dac. & Da Silva et al., 2000 & $\begin{array}{l}\text { Zucchetti et al., 2000; } \\
\text { Baltazar \& Zucchetti, 2007; } \\
\text { Noce et al., } 2007\end{array}$ & $\begin{array}{l}\text { Submarine plateau (plume); } \\
\text { and island arc/backarc basin }\end{array}$ & VA \\
\hline & 22. Greenland & & & & & & \\
\hline 140. Isua & SW Greenland & 3800 & Pl.gr., fel. rocks & $\begin{array}{l}\text { Polat \& Hofmann, 2003; } \\
\text { Komiya et al., 2004; }\end{array}$ & $\begin{array}{l}\text { Polat \& Hofmann, 2003; } \\
\text { Komiya et al., 2004; }\end{array}$ & Plume to SSZ & BA-FA \\
\hline
\end{tabular}


Table 1. Summary of ophiolitic sequences, their felsic rock types and suggested tectonic enviromnment and ophiolite types

\begin{tabular}{|c|c|c|c|c|c|c|c|}
\hline & & & & Furnes et al., 2007 & Furnes et al., 2007 & & \\
\hline & 23. Africa & & & & & & \\
\hline 141. Leerkrans Fm & South Africa & 1300 & Pyroclast & Bailie et al., 2011 & Bailie et al., 2011 & Continental backarc basin & BA \\
\hline 142. Bas Draa & Morocco & 1380 & Rhy. & El Bahat et al., 2013 & El Bahat et al., 2013 & Rift magmatism & $\mathrm{R} / \mathrm{CM}$ \\
\hline 143. Chewore & Kalahari - Congo, Africa & 1400 & And., dac., rhy. & Johnson \& Oliver, 2000 & Johnson \& Oliver, 2000 & Marginal basin & $B A$ \\
\hline 144. Birimian terrane & Western Africa & 2100 & And., dac., rhy. & Vidal \& Alric, 1994 & $\begin{array}{l}\text { Abouchami \& Boher, 1990; } \\
\text { Sylvester \& Attoh, 1992; } \\
\text { Vidal \& Alric, } 1994\end{array}$ & $\begin{array}{l}\text { Backarc immature arc } \\
\text { on oceanic crust }\end{array}$ & BA \\
\hline 145. Belingwe & Zimbabwe & $2900-2700$ & And. & Bolhar et al., 2003 & $\begin{array}{l}\text { Kusky \& kidd, 1992; } \\
\text { Bolhar et al., 2003; } \\
\text { Hofmann \& Kusky, } 2004\end{array}$ & $\begin{array}{l}\text { 1. Intra-oceanic MP; } \\
\text { 2. Ensialic rift above MP } \\
\text { 3. Backarc oceanic crust }\end{array}$ & BA-FA \\
\hline $\begin{array}{l}\text { 146. Noisy Complex, } \\
\text { Barberton }\end{array}$ & South Africa & 3455 & Ton.; rhy.dac. & $\begin{array}{l}\text { de Wit et al., 1987; } \\
\text { Louzada, 2003: } \\
\text { Furnes et al., } 2013\end{array}$ & & Island arc & VA \\
\hline & $\begin{array}{l}\text { 24. Ophiolitic } \\
\text { sequences unrelated } \\
\text { to orogenic belts }\end{array}$ & & & & & & \\
\hline 147. Taitao & Chile & 6 & Dac., try.dac., rhy. & Guivel et al., 1999 & $\begin{array}{l}\text { Le Moigne et al., 1996; } \\
\text { Guivel et al., 1999; } \\
\text { Veloso et al., 2005, } 2009\end{array}$ & Mid-ocean ridge & MOR \\
\hline 148. Tihama Asir & Red Sea, Saudi Arabia & $23-19$ & Rhy., gr.phy. & Dilek \& Furnes (unpubl. data) & Dilek \& Furnes (unpubl.data) & Rift stage, incipient oc. crust & $\mathrm{P} / \mathrm{MOR}$ \\
\hline 149. Iceland & Mid-Atlantic Ridge & $<1$ & $\begin{array}{l}\text { Ice.di., rhy. (mainly); } \\
\text { gr., gr.di. }\end{array}$ & $\begin{array}{l}\text { MacDonald et al., 1990; } \\
\text { Furman et al., 1992; } \\
\text { Hemond et al., 1993; } \\
\text { Gunnarson et al., 1998; } \\
\text { Martin \& Sigmarssson, } 2007\end{array}$ & Hemond et al., 1993 & Plume/mid-ocean ridge & $\mathrm{P} / \mathrm{MOR}$ \\
\hline & 25. In-situ oceanic crust & & & & & & \\
\hline 150. EPR & Pacific Ocean & $<0.03$ & Dac. & Wanless et al., 2010 & Pandey et al., 2013 & Mid-ocean ridge & MOR \\
\hline 151. K-PR & Philippine Sea & 38 & Ton. & Haragushi et al., 2003 & Haragushi et al., 2012 & $\begin{array}{l}\text { Early stage in oceanic } \\
\text { island arc formation }\end{array}$ & BA-FA \\
\hline 152. MSC & Manus Basin & $<1$ & Dac., rhy. & Beier et al., 2015 & Beier et al., 2015 & Backarc basin & BA \\
\hline 153. ESR & E Scotia Sea & $<1$ & Dac. & Leat et al., 2000 & Leat et al., 2000 & Backarc basin & BA \\
\hline 154. Kermadec arc & Lau Basin & $<1$ & Dac., rhy. & Smith et al., 2003a,b & Ewart et al., 1977 & Oceanic arc & BA-FA \\
\hline 155. Spreading axes & Lau Basin & $<1$ & And. & Pearce et al., 1994 & Pearce et al., 1994 & Backarc basin & $\mathrm{BA}$ \\
\hline 156. IBM & Bonin Isl., Japan & $46-48$ & Fel. rocks & $\begin{array}{l}\text { Ishizuka et al., 2006; } \\
\text { Reagan et al., } 2010\end{array}$ & $\begin{array}{l}\text { Ishizuka et al., 2006; } \\
\text { Reagan et al., } 2010\end{array}$ & Forearc & FA \\
\hline
\end{tabular}


Abbreviations: Column A: East Pacific Rise: EPR; East Scotia Ridge: ESR; Izu-Bonin-Mariana: IBM; KyushiPalau Ridge: K-PR; Manus Spreading Centre: MSC; Melange: Mel. Column B: California: Cal. Column C: Mesozoic: Mes., Cambrian: Camb., Ordovician: Ord., Permian: Perm., Triassic: Trias., Jurassic: Jur., Cretaceous: Cret. Column D: Albite granite: Alb.gr.; Andesite: And.; Basaltic andesite: Bas. and.; Dacite: Dac.; Dike: Dk.; Diorite: Di.; Diorite porphyry: Di.porph.; Felsic: Fel.; Granodiorite: Gr.di.; Granite: Gr.; Granophyre: Gr.phy.; Hornblende-plagioclase porphyry: Hbl-pl.porph.; Icelandite: Isl.di.; Intermediate: interm.; Keratophyre: Ker.; Leucodiorite: Leucodi.; Leucogranite: Leucogr.; Monzogranite: Mon.gr.; Plagiogranite: Pl.gr.; Quartz diorite: Quartz monzodiorite: Q-mon.di.; Q-di.; Quartz porphyry: Q-porph.; Rhyodacite: Rhy.dac.; Rhyolite: Rhy.; Tonalite: Ton.; Trachydacite: Try.dac.; Trondhjemite: Tr.hj.ite.; Volcanics: Volc. Column F: Shafaii Moghadam: Sh.Mogh.; Van Kranendonk \& Pirajno: Van Kr. \& Pir. Column G: Ensimatic: Ensim., Lithosphere: Li.sph.; Magmatism: Magm., Mantle plume: MP; Marginal basin: Marg.bas.; Oceanic: Oc.; Seafloor spreading: Sfs.; Subducted: Subd.; Suprasubduction zone: SSZ. Column H: Rift/Continental Margin: Rift/CM; Mid-ocean-ridge: MOR; Plume/MOR: P/MOR; Backarc: BA; Backarc to Forearc: BA-FA; Forearc: FA; Volcanic Arc: VA. In italics: ophiolite type suggested from literature. 
Table 2. Proxies for subduction and melting for Phanerozoic, Proterozoic and Archean ophiolites

\begin{tabular}{|c|c|c|c|c|c|c|c|c|c|c|c|c|c|}
\hline \multirow{3}{*}{$\begin{array}{l}\text { Ophiolite Type } \\
\text { Phanerozoic Complexes } \\
\text { Subduction-unrelated }\end{array}$} & \multirow{3}{*}{$\begin{array}{c}\text { Percent } \\
\text { subduction } \\
\text { influence }\end{array}$} & \multicolumn{5}{|c|}{ Th/Yb-proxy for subduction (\%) } & \multirow{2}{*}{\multicolumn{3}{|c|}{$\begin{array}{c}\text { V - Ti proxy } \\
\text { for SSZ melting (\%) }\end{array}$}} & \multicolumn{4}{|c|}{$\mathrm{Ti} / \mathrm{Yb}$ proxy for plume melting (\%) } \\
\hline & & \multirow{2}{*}{$\begin{array}{c}\text { Mantle } \\
\text { array }\end{array}$} & \multirow[b]{2}{*}{ weak } & \multirow{2}{*}{$\begin{array}{l}\text { oceanic } \\
\operatorname{arc}(o a)\end{array}$} & \multirow{2}{*}{$\begin{array}{c}\text { Cont. } \\
\operatorname{arc}(c a)\end{array}$} & \multirow{2}{*}{$\begin{array}{l}\text { Joint } \\
\text { oa/ca }\end{array}$} & & & & \multicolumn{2}{|c|}{ MORB - shallow } & \multicolumn{2}{|c|}{ MORB - deep } \\
\hline & & & & & & & Bon & IAT & MORB & N-MORB & E-MORB & Thol. & Alk. \\
\hline Rift/Continental margin (1) & 0 & 100 & 0 & 0 & 0 & 0 & 0 & 0 & 0 & 0 & 0 & 100 & 0 \\
\hline MORB (18) & $0-10(2)$ & 90-100 (98) & $0-8(1)$ & $0-6(0.3)$ & 0 & $0-10(0.7)$ & 0 & $0-100(40)$ & $0-100(60)$ & $0-100(66)$ & $0-100(23)$ & $0-67(10)$ & $0-8(1)$ \\
\hline Plume (4) & $0-10(4)$ & $90-100(96)$ & $0-10(4)$ & 0 & 0 & 0 & 0 & 0 & 100 & $0-30(8)$ & $0-29(7)$ & $31-100(77)$ & $0-33(8)$ \\
\hline \multicolumn{14}{|l|}{ Subduction-related } \\
\hline Backarc (35) & $6-100(50)$ & $0-94(50)$ & $0-78(31)$ & 0-75 (13) & 0 & $0-73(6)$ & $0-100(\mathbf{1})$ & $0-100(15)$ & $0-100(84)$ & $0-100(75)$ & $0-100(\mathbf{1 8})$ & $0-70(6)$ & $0-18(1)$ \\
\hline Backarc to forearc (22) & $25-100(74)$ & $0-75(26)$ & $0-64(19)$ & $0-92(35)$ & $0-16(3)$ & 0-57 (17) & 0-75 (16) & $0-100(\mathbf{5 3})$ & $0-75(31)$ & $0-100(84)$ & $0-50(8)$ & $0-100(8)$ & 0 \\
\hline Forearc (4) & $29-100(78)$ & $0-71(22)$ & $0-29(10)$ & $0-90(43)$ & $0-14(8)$ & $0-29(17)$ & $75-100(88)$ & $0-25(12)$ & 0 & $0-100(75)$ & $0-50(25)$ & 0 & 0 \\
\hline Forearc/Volcanic arc (3) & $55-100(78)$ & $0-45(22)$ & $0-20(12)$ & $0-20(7)$ & $31-40$ (37) & $0-60(22)$ & $0-66(29)$ & $17-40(27)$ & $17-60(44)$ & $0-100(50)$ & $0-92(46)$ & $0-8(4)$ & 0 \\
\hline \multicolumn{14}{|l|}{ Proterozoic Complexes } \\
\hline \multicolumn{14}{|l|}{ Subduction-unrelated } \\
\hline Rift/Continental margin (3) & 0 & 100 & & & & & & & & $0-25(8)$ & $25-100(67)$ & 0 & $0-75(25)$ \\
\hline $\operatorname{MORB}(4)$ & 0 & 100 & & & & & & & & $0-100(59)$ & $0-100(33)$ & $0-25(8)$ & 0 \\
\hline \multicolumn{14}{|l|}{ Subduction-related } \\
\hline Backarc (13) & $0-100(39)$ & $0-100(61)$ & $0-100$ (33) & $0-96(13)$ & $0-14(3)$ & $0-88(11)$ & 0 & $0-100(28)$ & $0-100(72)$ & $0-100(42)$ & $0-100(37)$ & $0-100(21)$ & 0 \\
\hline Backarc to forearc (9) & 70-98 (82) & $2-30(18)$ & 0-30 (11) & $0-64(32)$ & $0-29(11)$ & $0-60(28)$ & $0-45(21)$ & $6-59(33)$ & $6-81(46)$ & $0-100(50)$ & $0-100(25)$ & $0-100(25)$ & 0 \\
\hline Forearc (3) & $33-100(72)$ & $0-67(28)$ & $0-17(6)$ & $0-100$ (39) & $0-8(3)$ & $0-40(24)$ & $36-100(79)$ & $0-64(21)$ & 0 & 100 & 0 & 0 & 0 \\
\hline Forearc/Volcanic arc (7) & $46-100(80)$ & $0-54(20)$ & $0-8(1)$ & 0 & $0-100(36)$ & $0-100(43)$ & 0 & $50-100(68)$ & $0-50(32)$ & $0-100(25)$ & $0-100(61)$ & $0-30(8)$ & $0-25(6)$ \\
\hline \multicolumn{14}{|l|}{ Archean Complexes } \\
\hline \multicolumn{14}{|l|}{ Subduction-unrelated } \\
\hline \multicolumn{14}{|l|}{ Rift/Continental margin (0) } \\
\hline $\operatorname{MORB}(1)$ & 50 & 50 & & & & & & & & & & & \\
\hline Plume (1) & 0 & 100 & & & & & & & & 100 & & & \\
\hline \multicolumn{14}{|l|}{ Subduction-related } \\
\hline Backarc (10) & $10-79(57)$ & $21-90(43)$ & $10-65(45)$ & $5-82(17)$ & 0 & $0-18(5)$ & $0-27(5)$ & $0-70(63)$ & $19-100(32)$ & $0-100(49)$ & $0-75(21)$ & $0-50(28)$ & $0-13(2)$ \\
\hline Backarc to forearc (10) & $21-100(78)$ & $0-79(22)$ & $15-94(48)$ & $0-60(10)$ & $0-31(3)$ & $0-40(17)$ & $0-56(11)$ & $16-100(56)$ & $0-82(33)$ & $0-100(80)$ & $0-100(12)$ & $0-50(8)$ & 0 \\
\hline Forearc (4) & $63-100(83)$ & 0-37 (17) & $0-100(44)$ & 0-50 (12) & $0-22(6)$ & $0-50(21)$ & $0-26(7)$ & $94-100(93)$ & 0 & $0-30(15)$ & 0 & $70-100(85)$ & 0 \\
\hline Forearc/Volcanic arc (14) & $62-100(91)$ & $0-38(9)$ & $0-28(6)$ & $0-33(5)$ & $0-90(17)$ & $10-100(63)$ & $0-35(5)$ & $0-100(41)$ & $0-100(54)$ & $0-100(47)$ & $0-100(30)$ & $0-70(23)$ & 0 \\
\hline
\end{tabular}



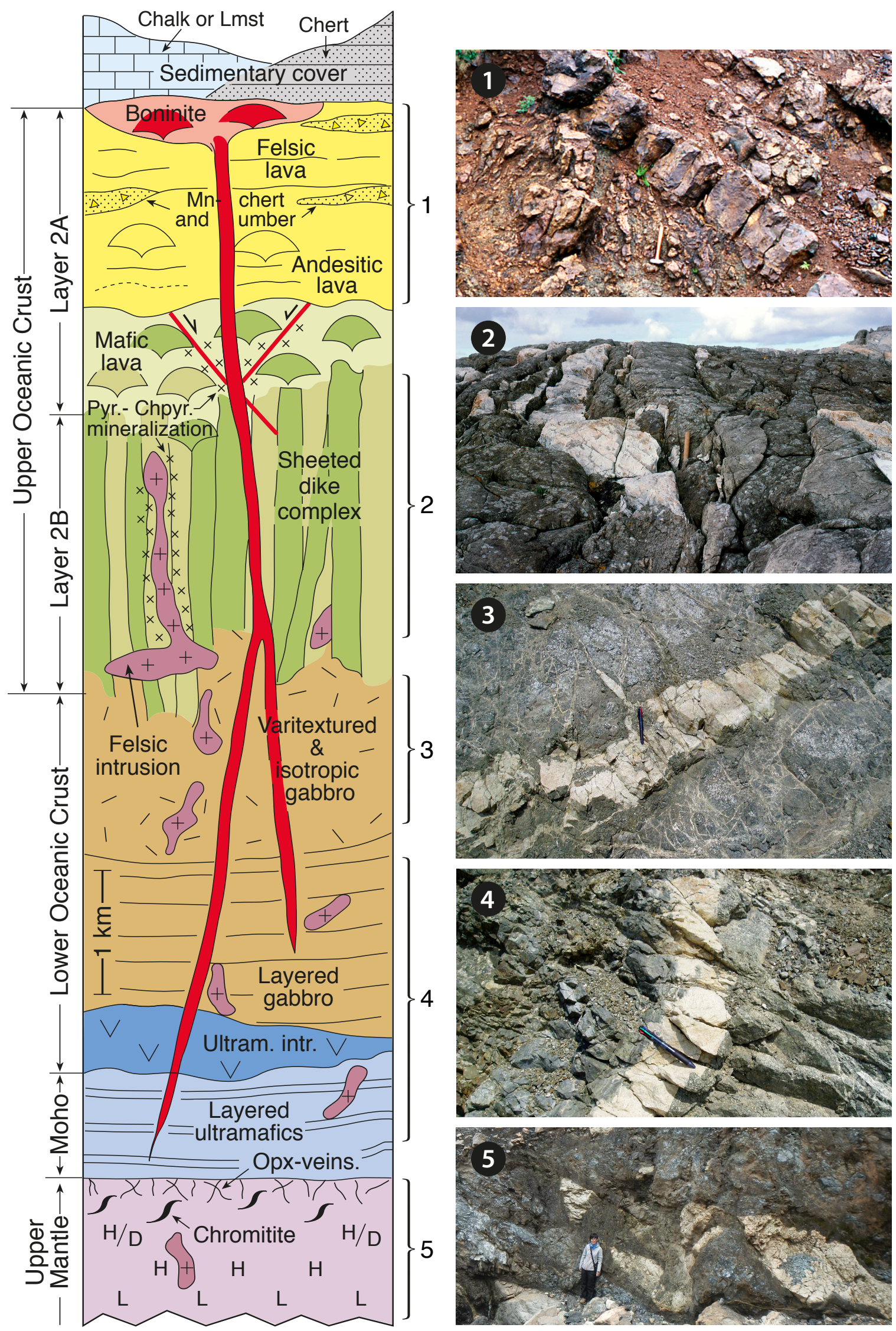
Figure 3

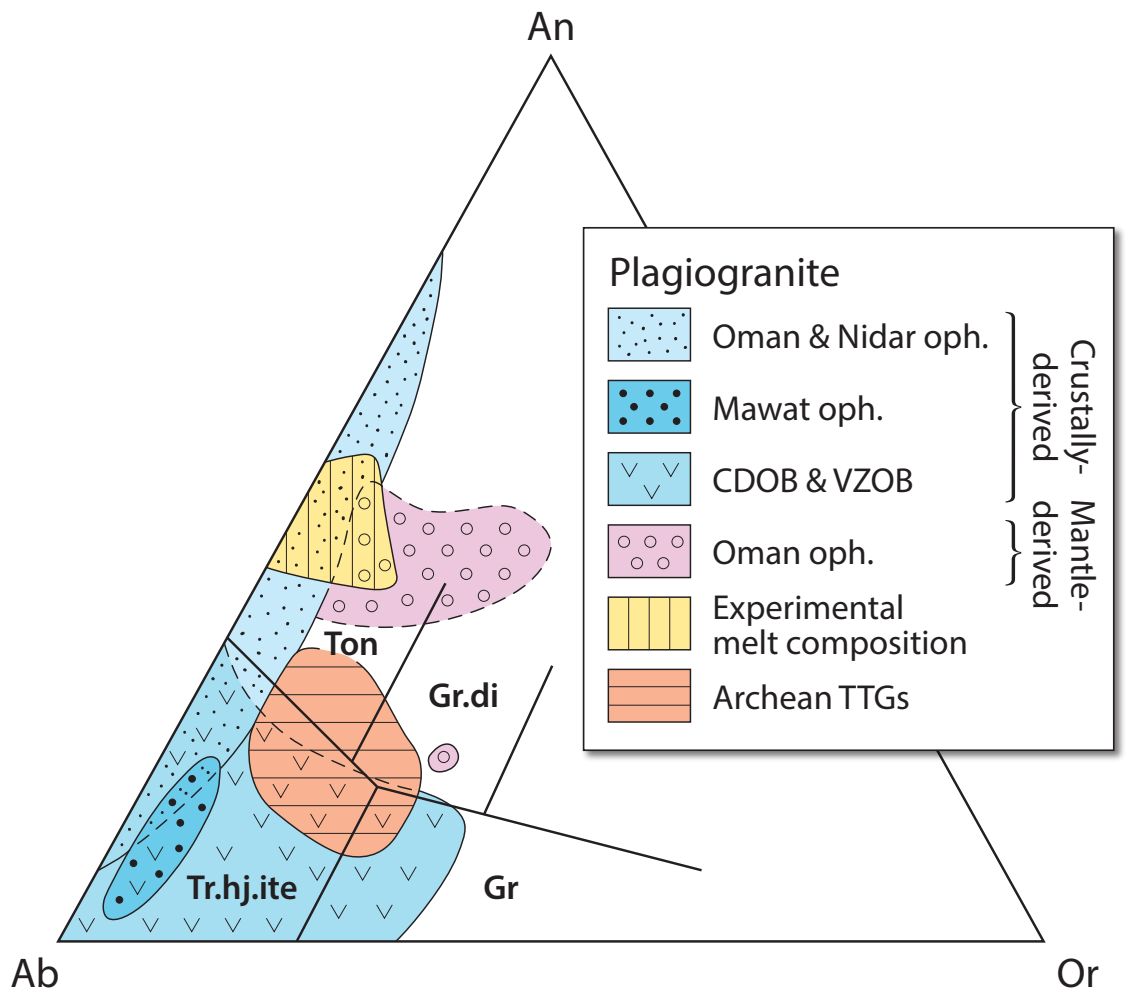



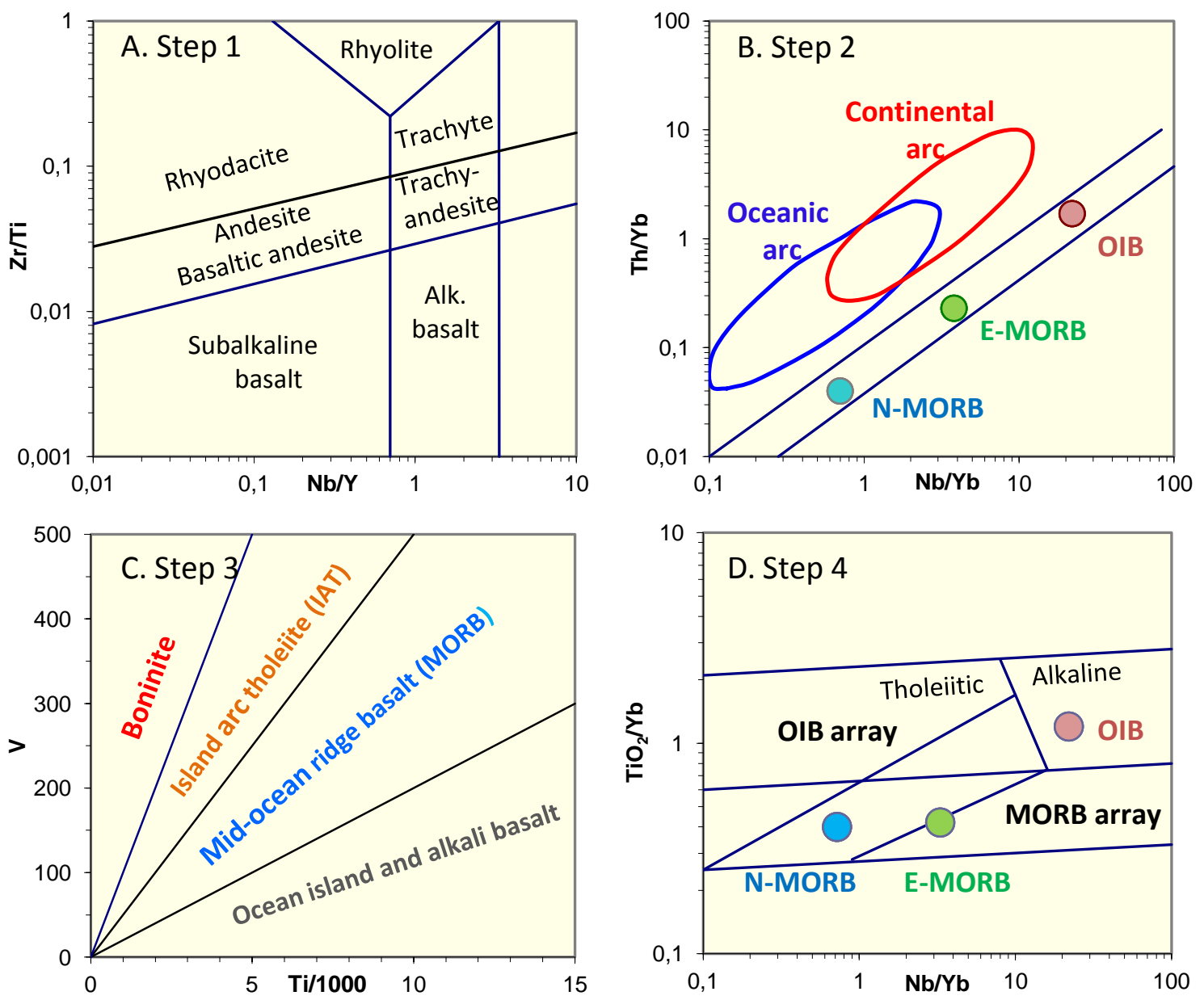


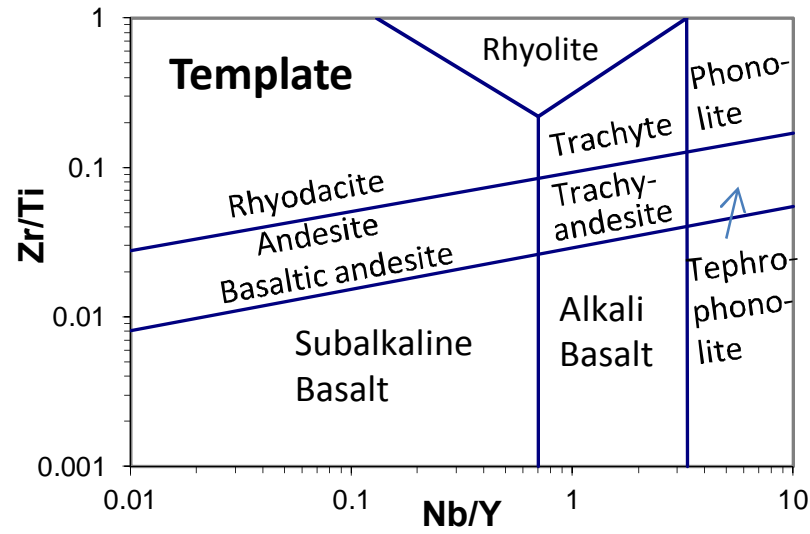

Subduction-unrelated ophiolite types
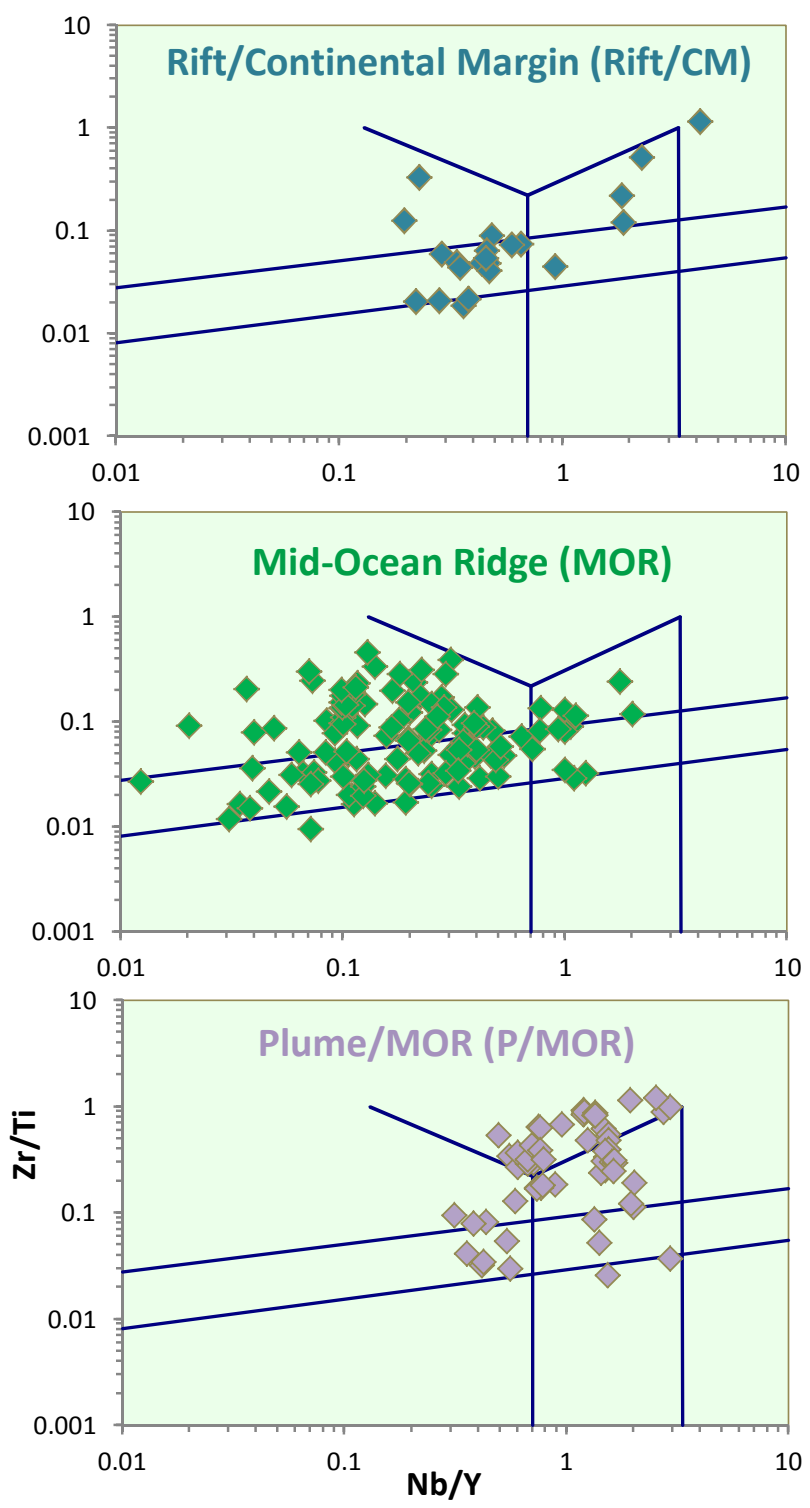

Subduction-related ophiolites types
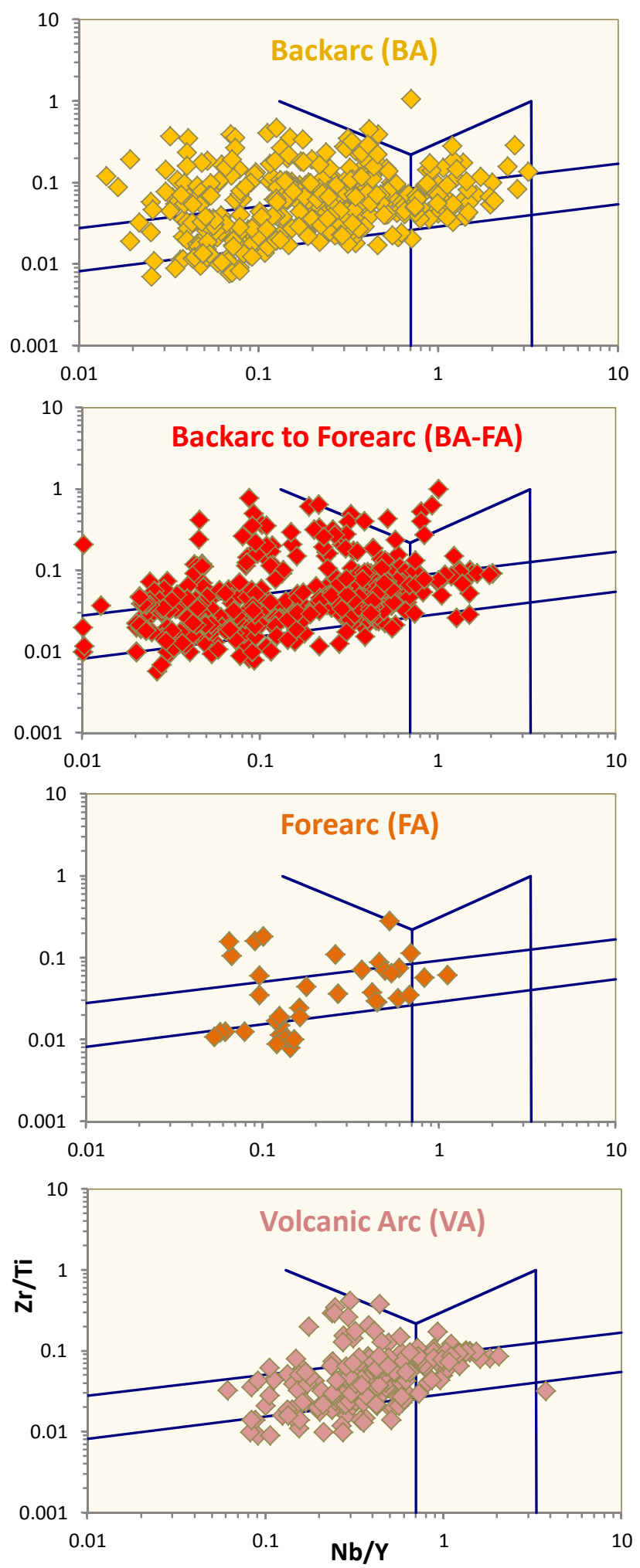
A. Subduction-unrelated ophiolite types

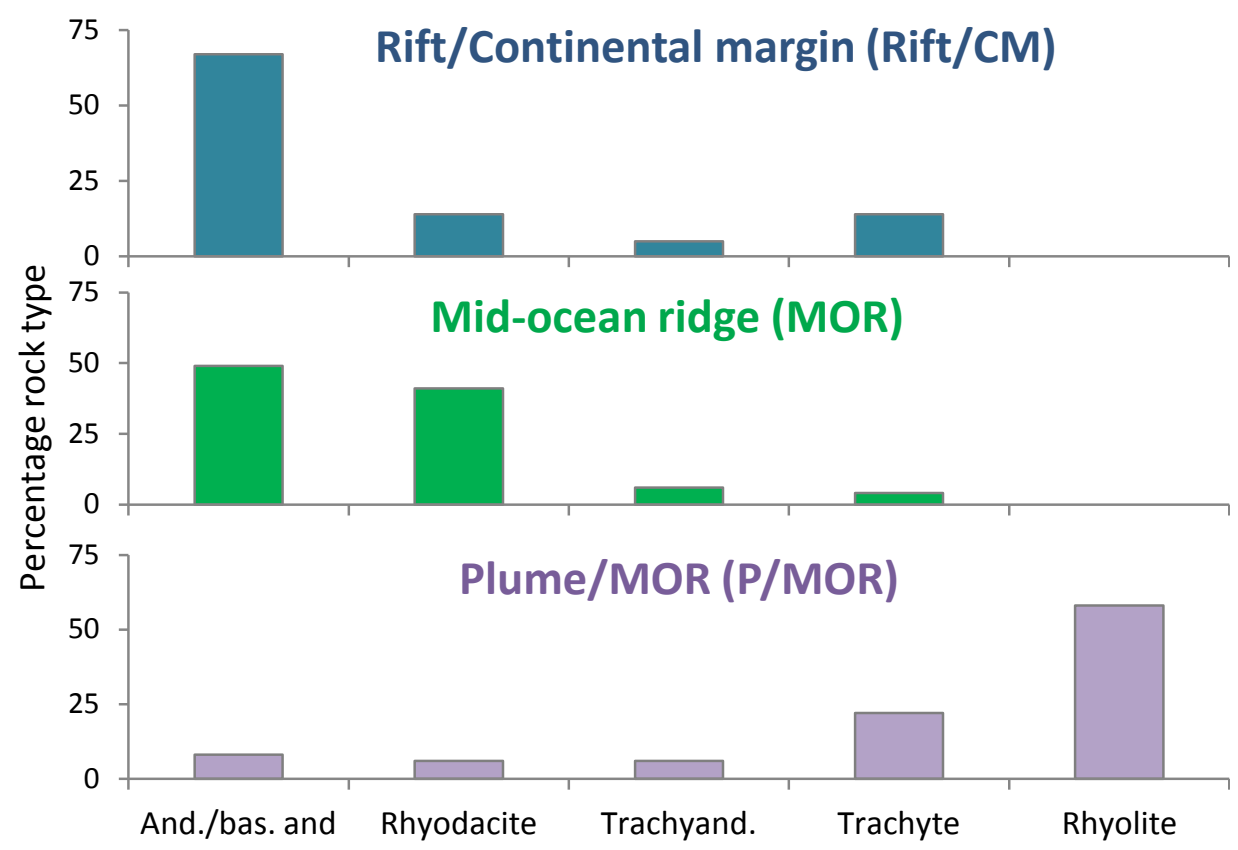

B. Subduction-related ophiolite types

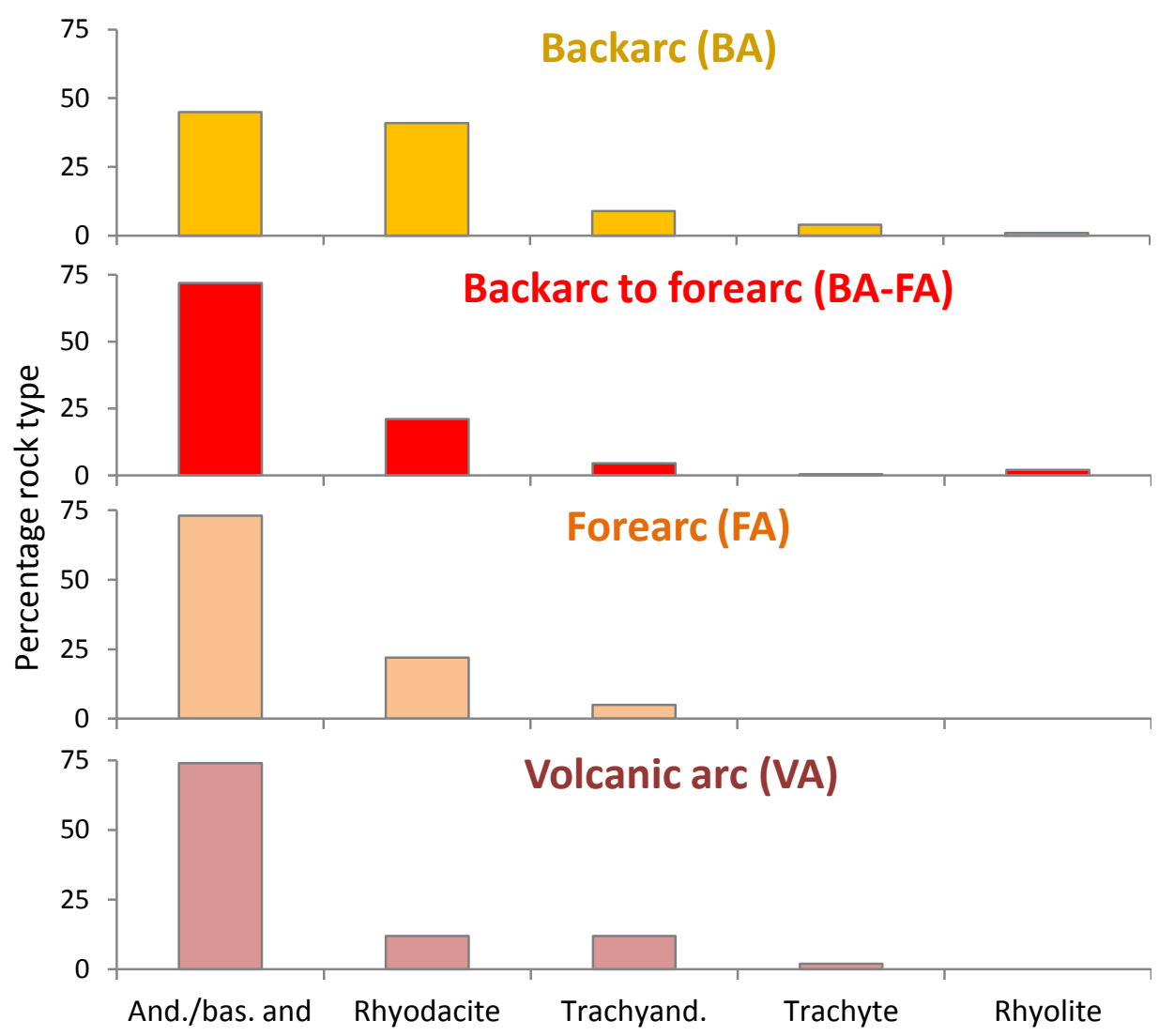



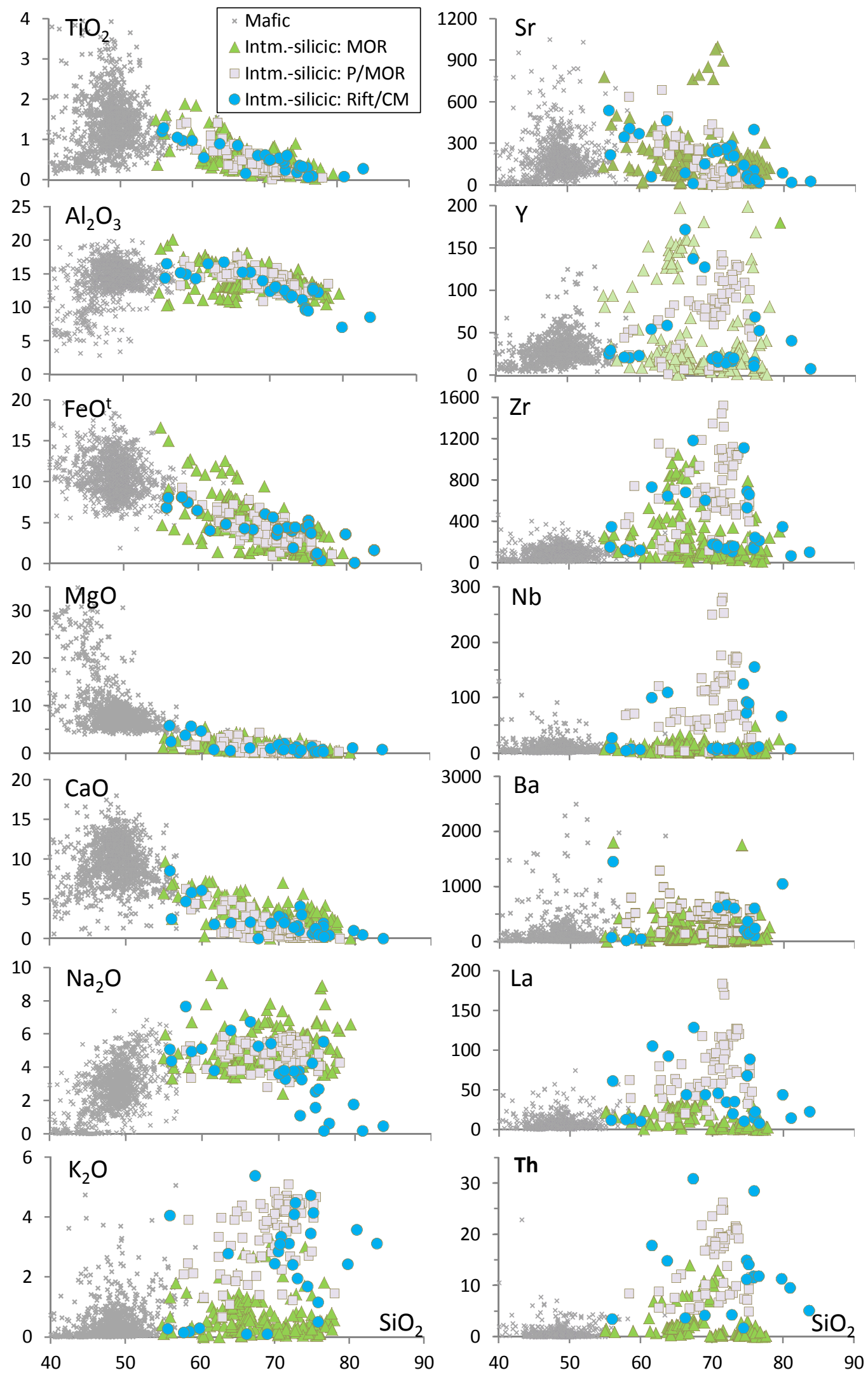


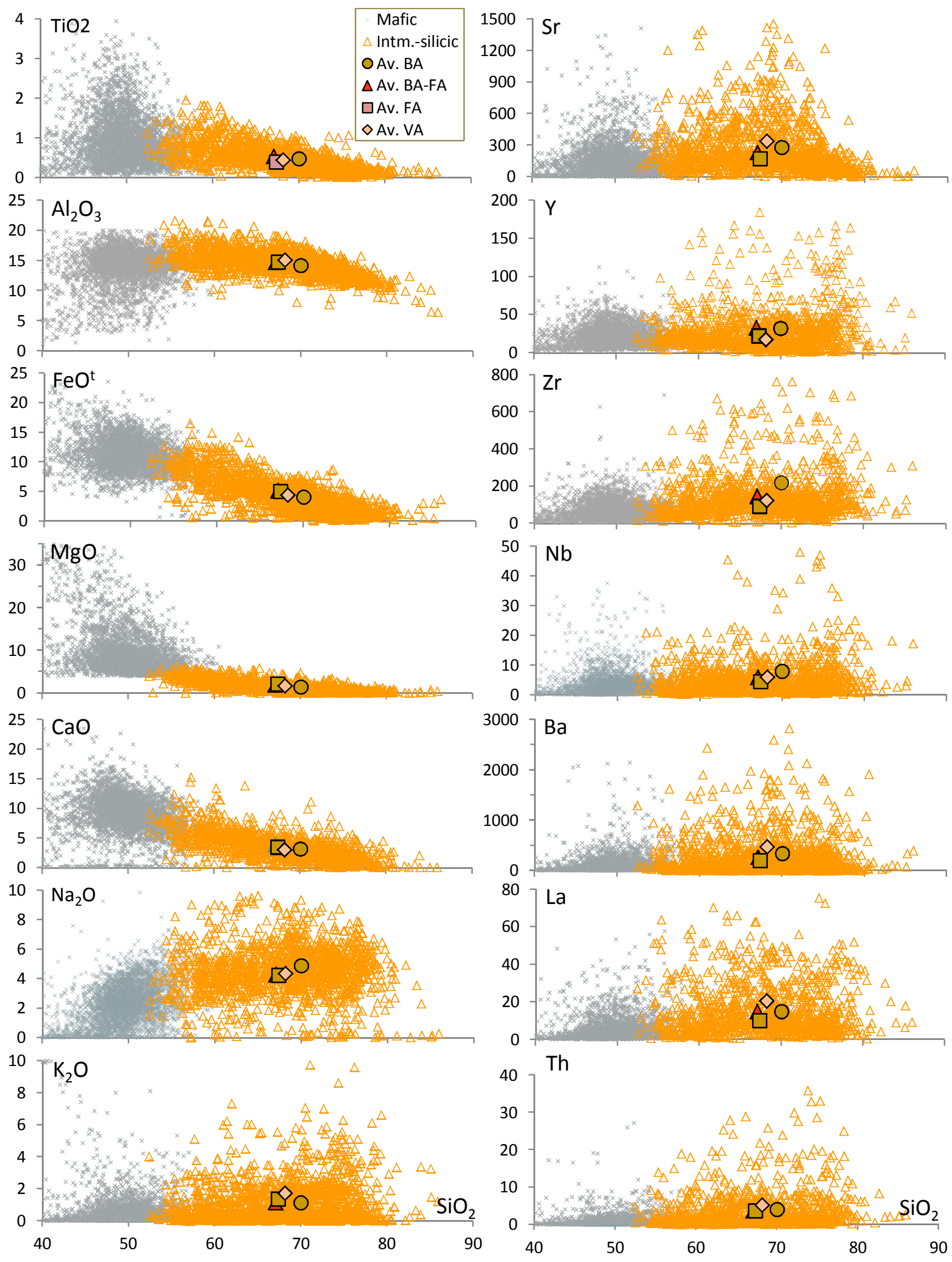




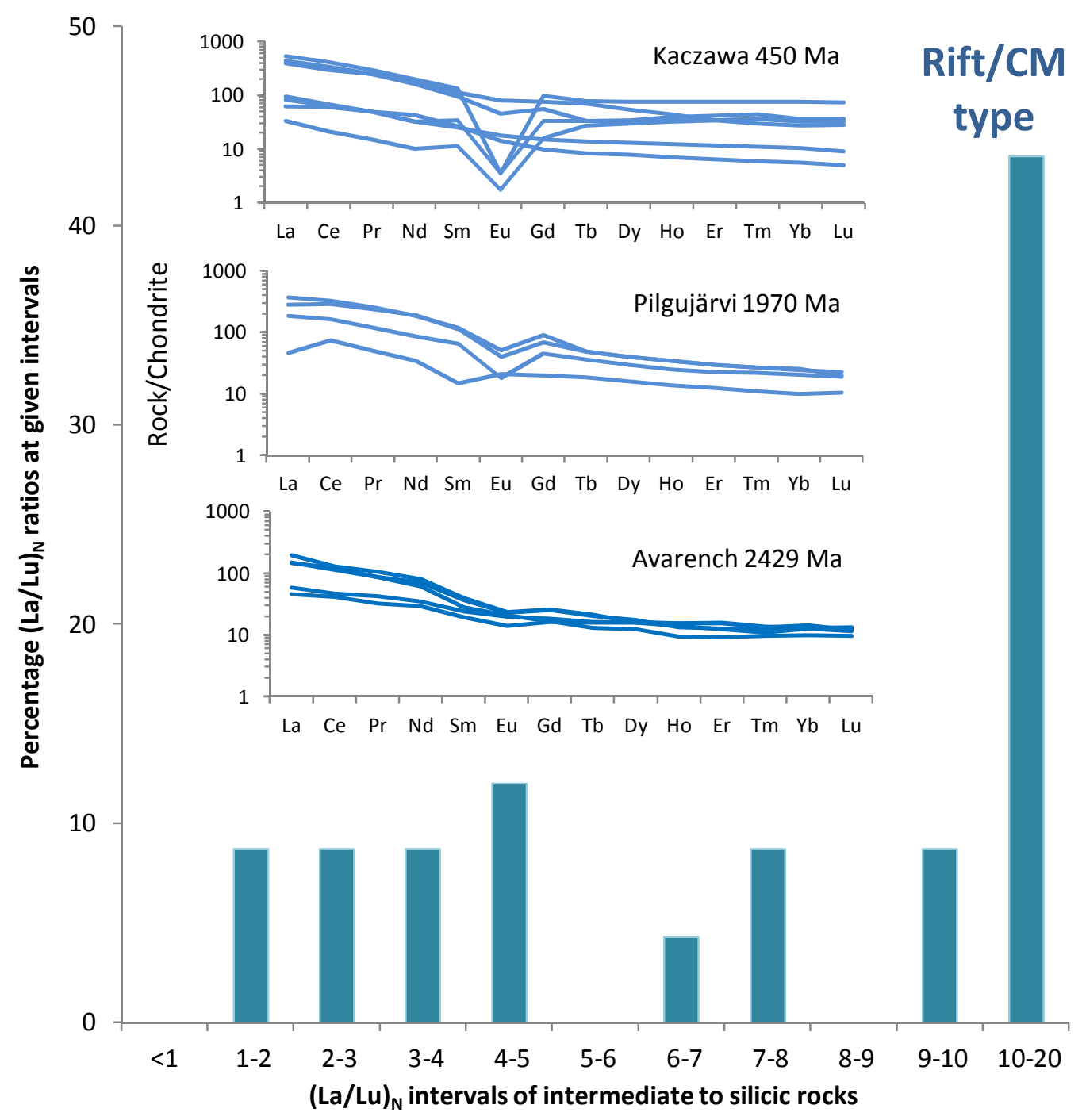





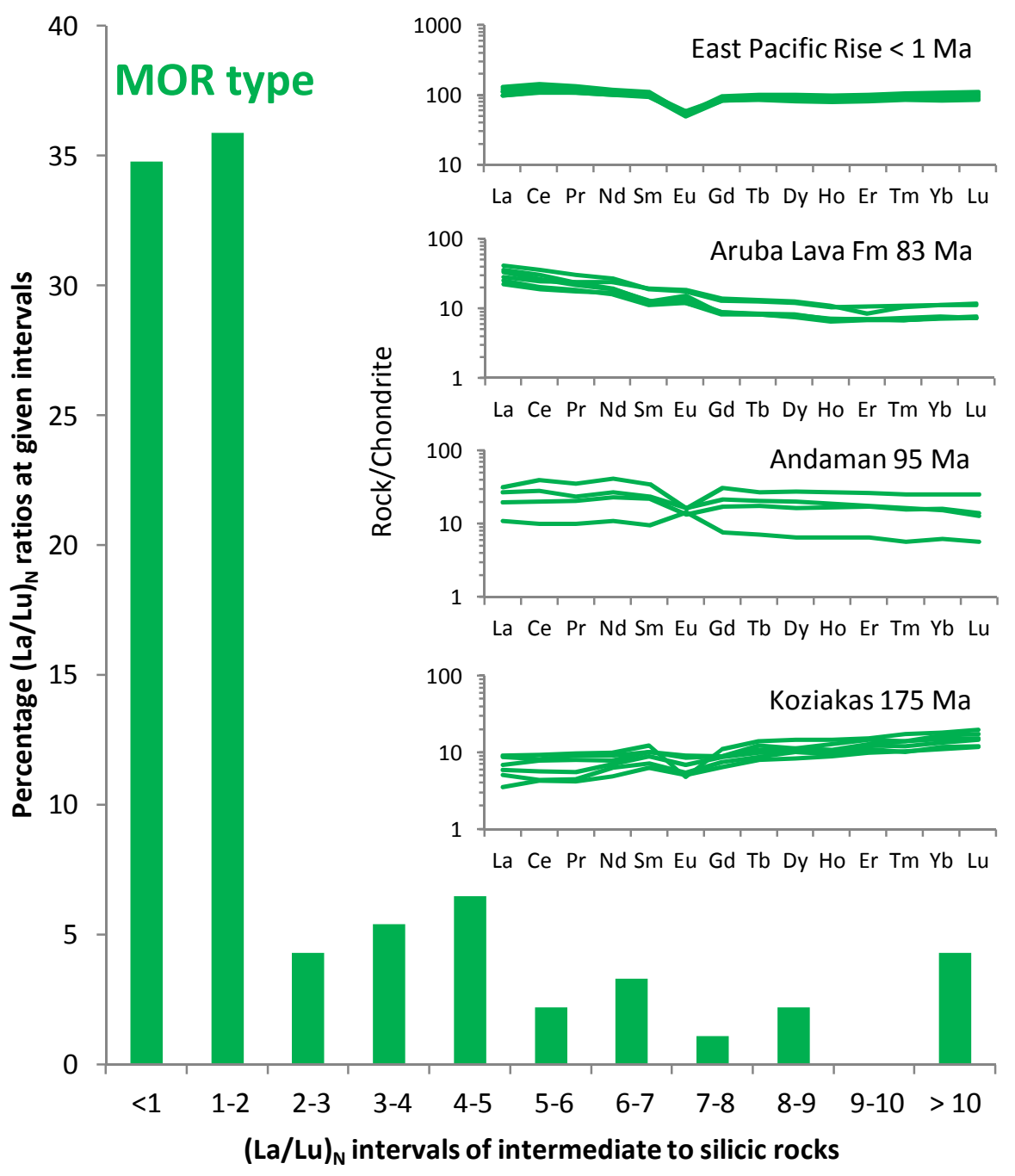




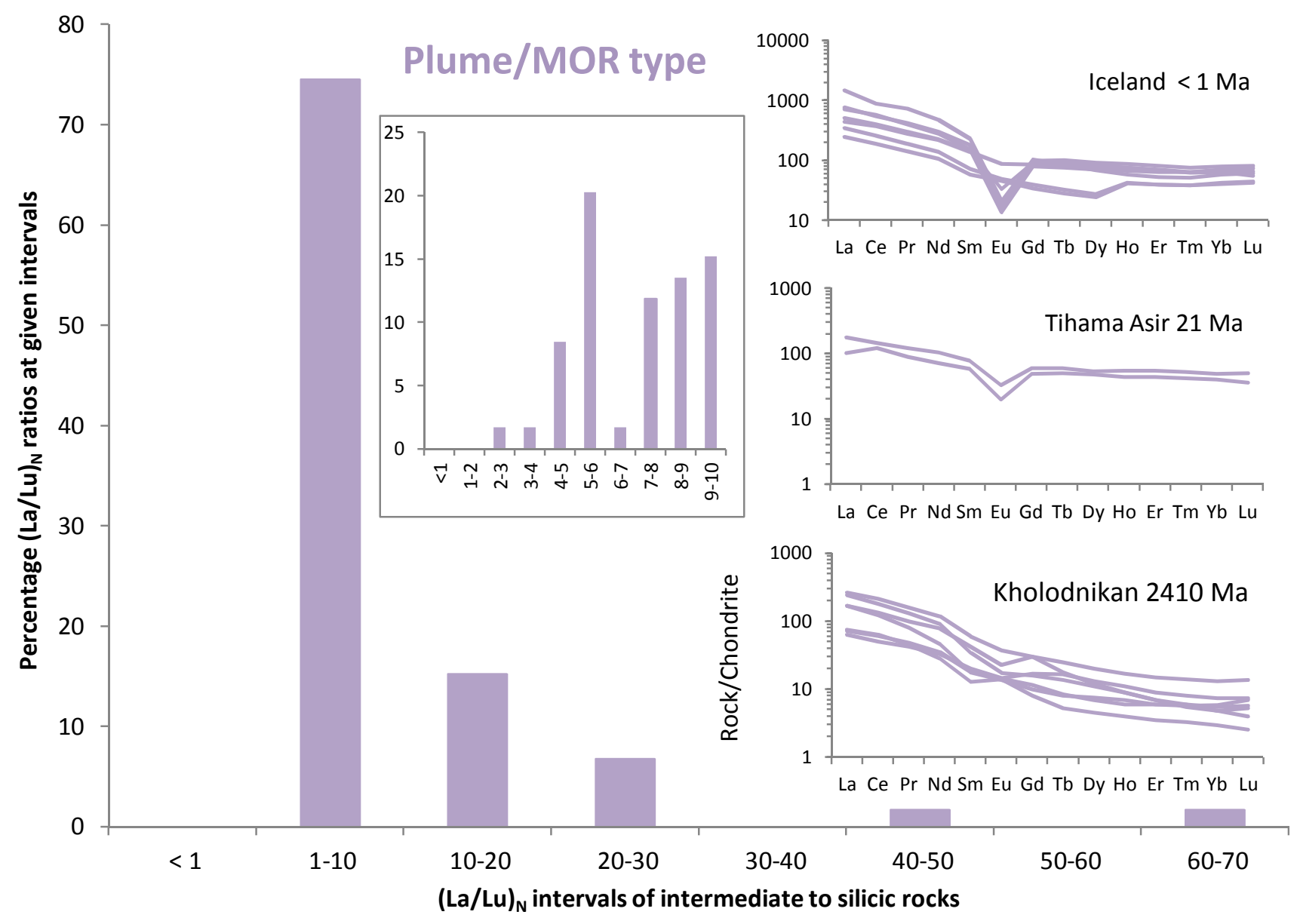




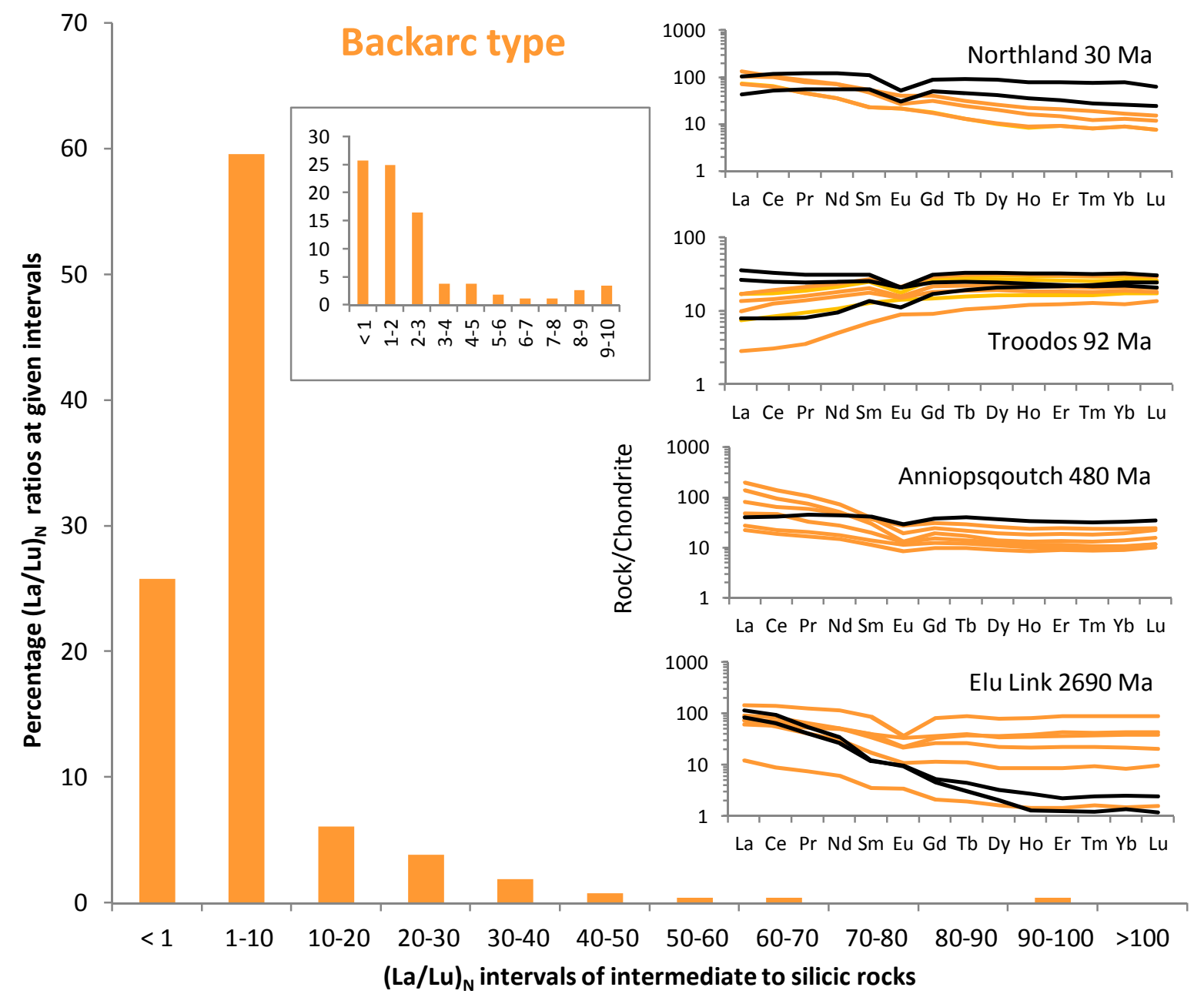




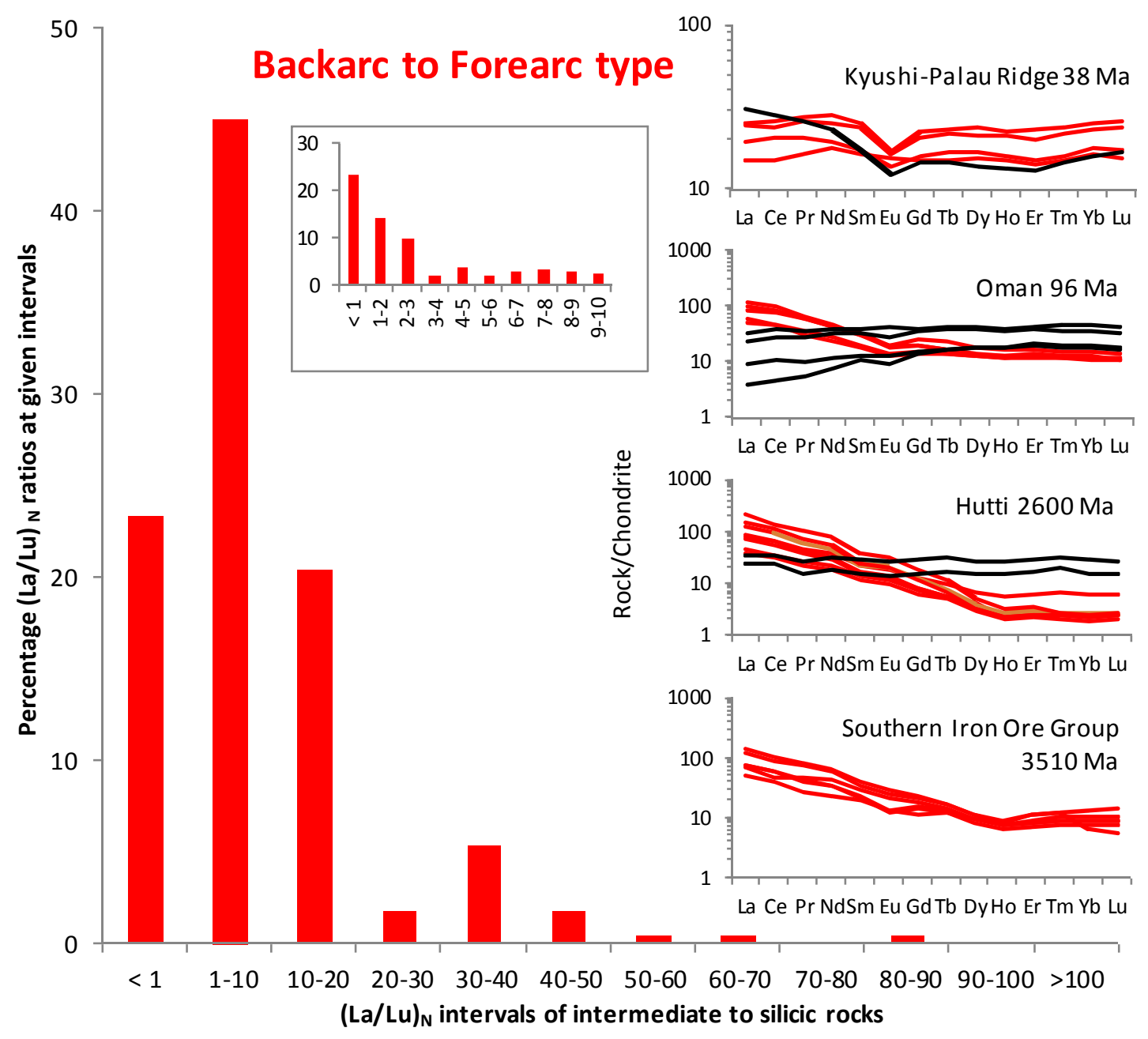




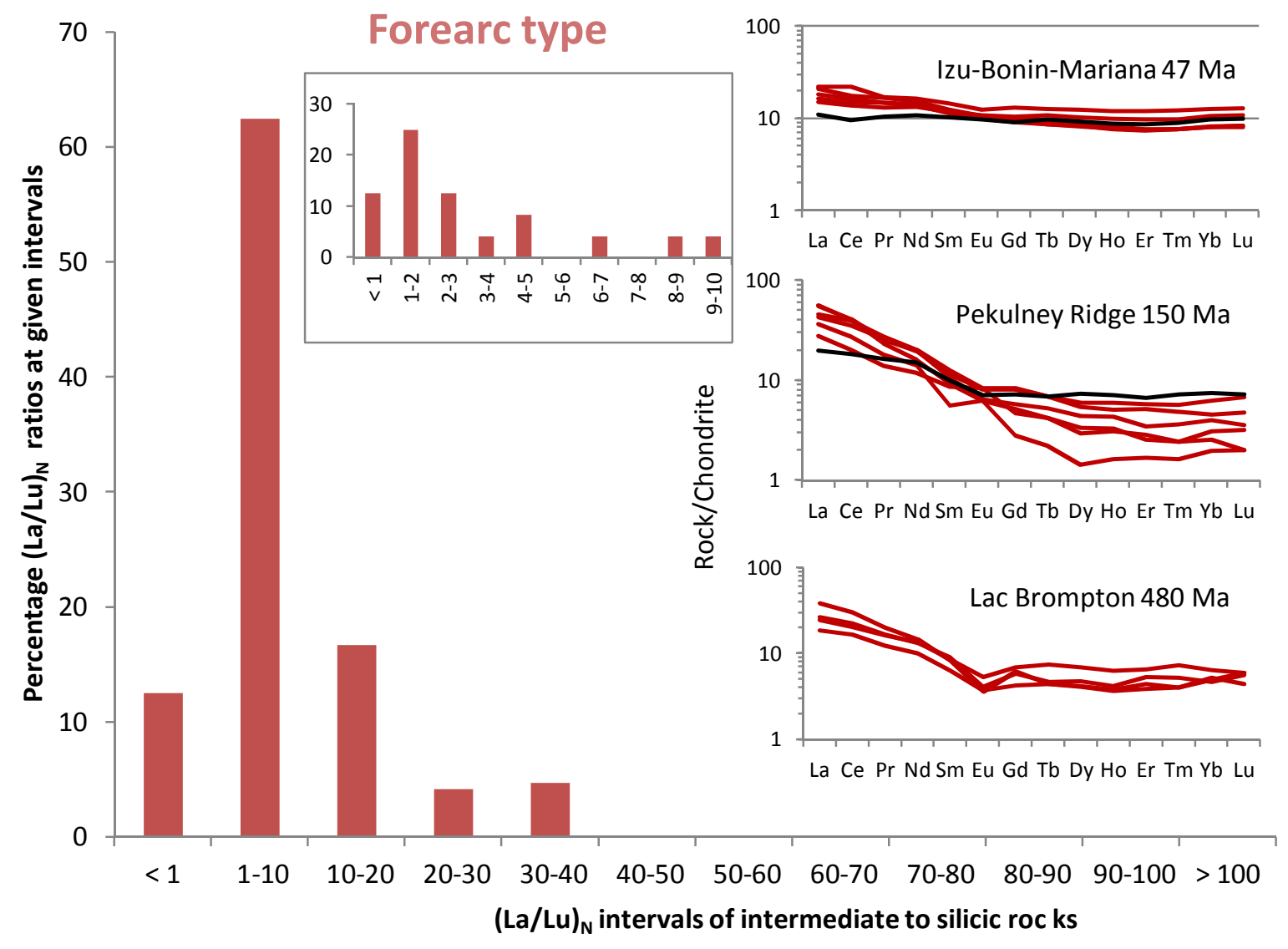




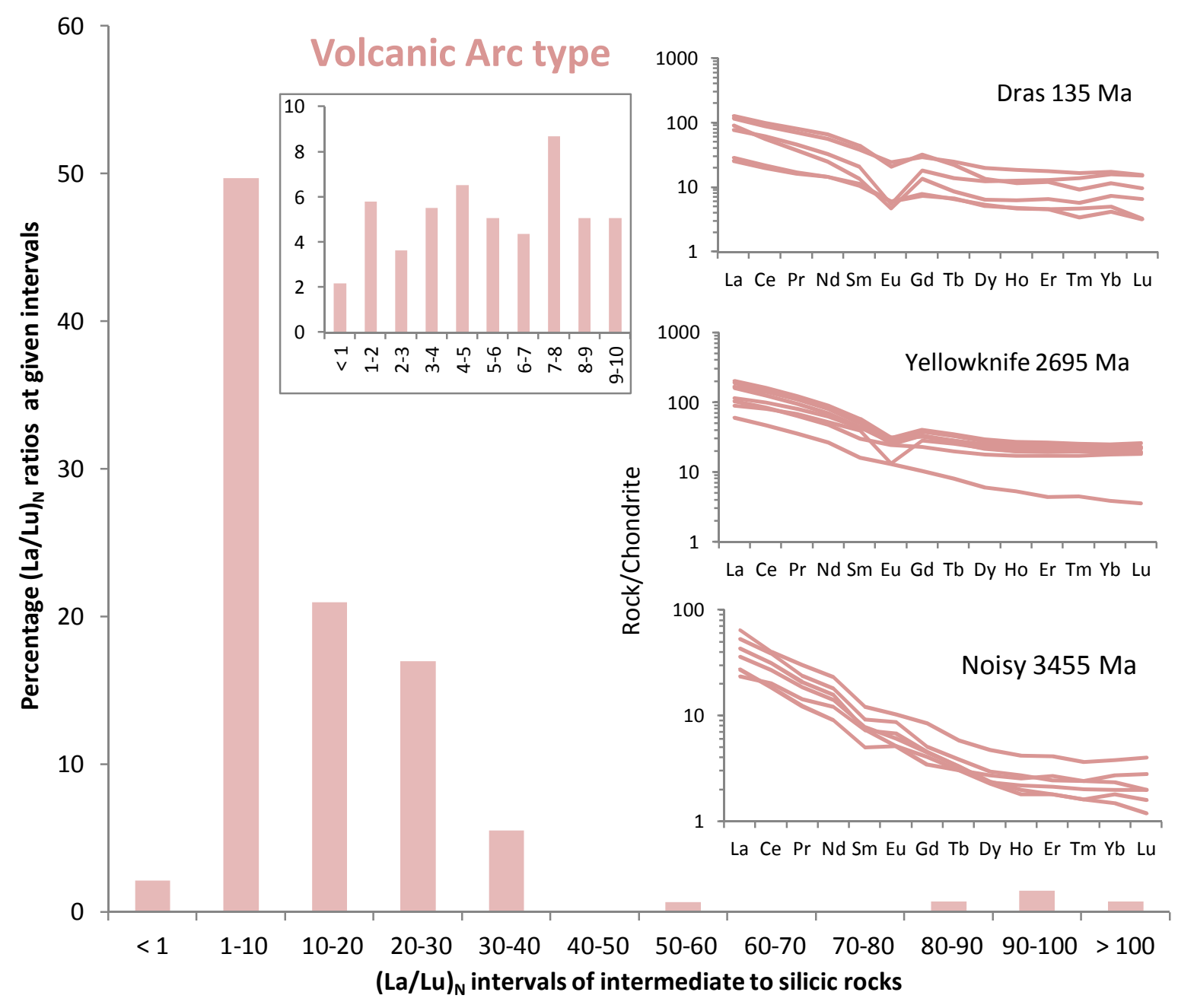


Rift/CM type

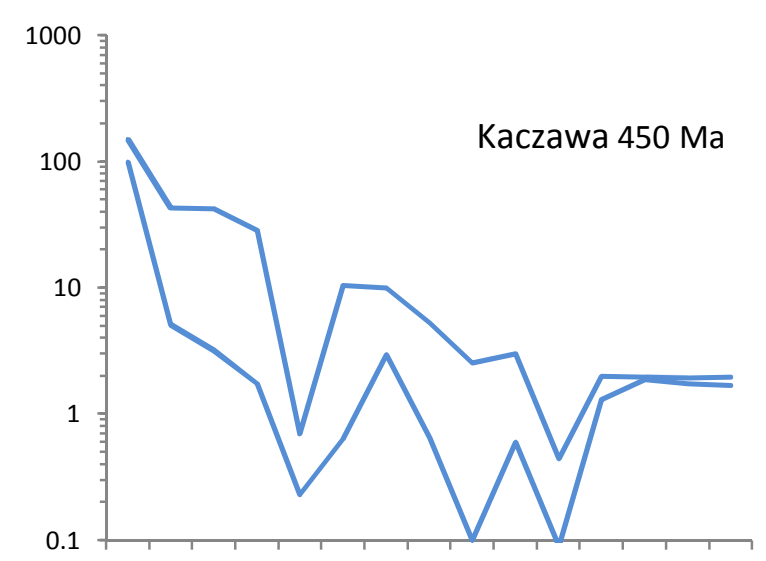

Th Nb La Ce Sr Nd Zr Sm Eu Gd Ti Dy Y Yb Lu
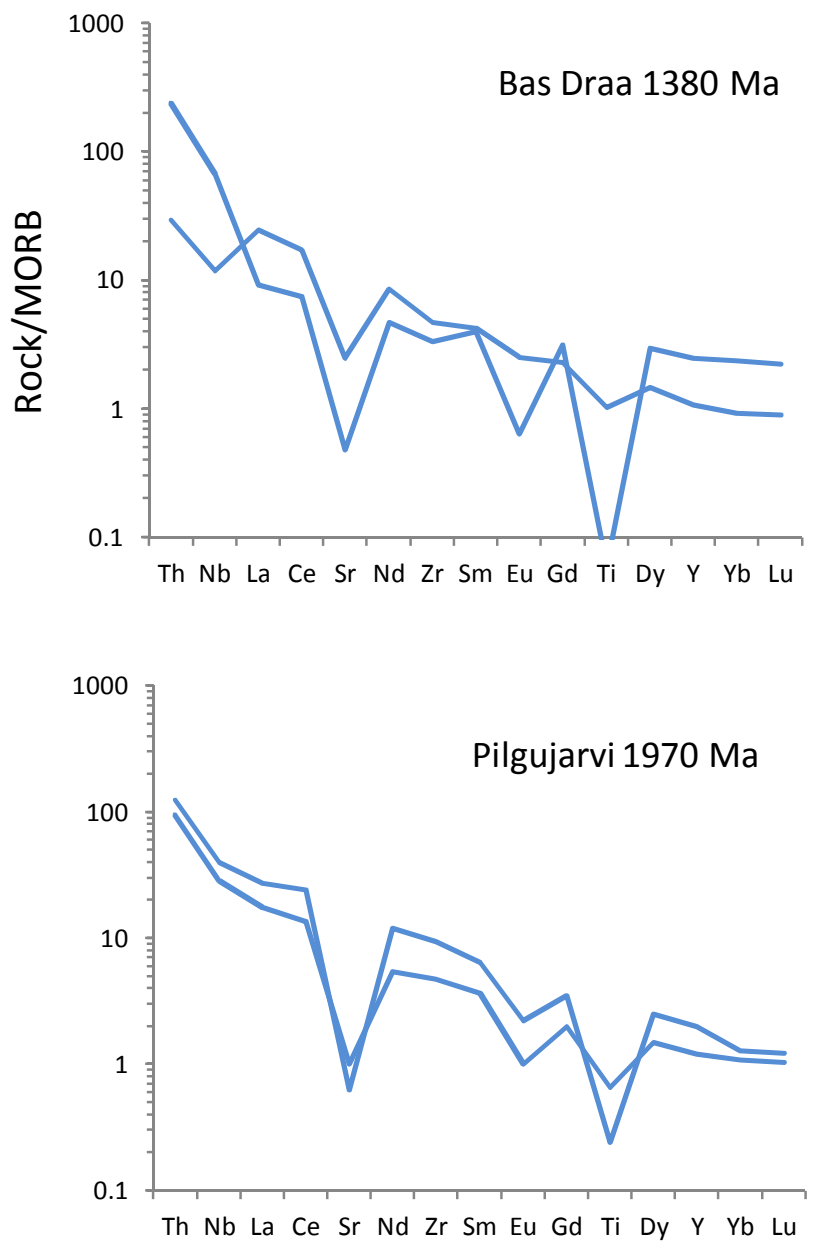

MOR type
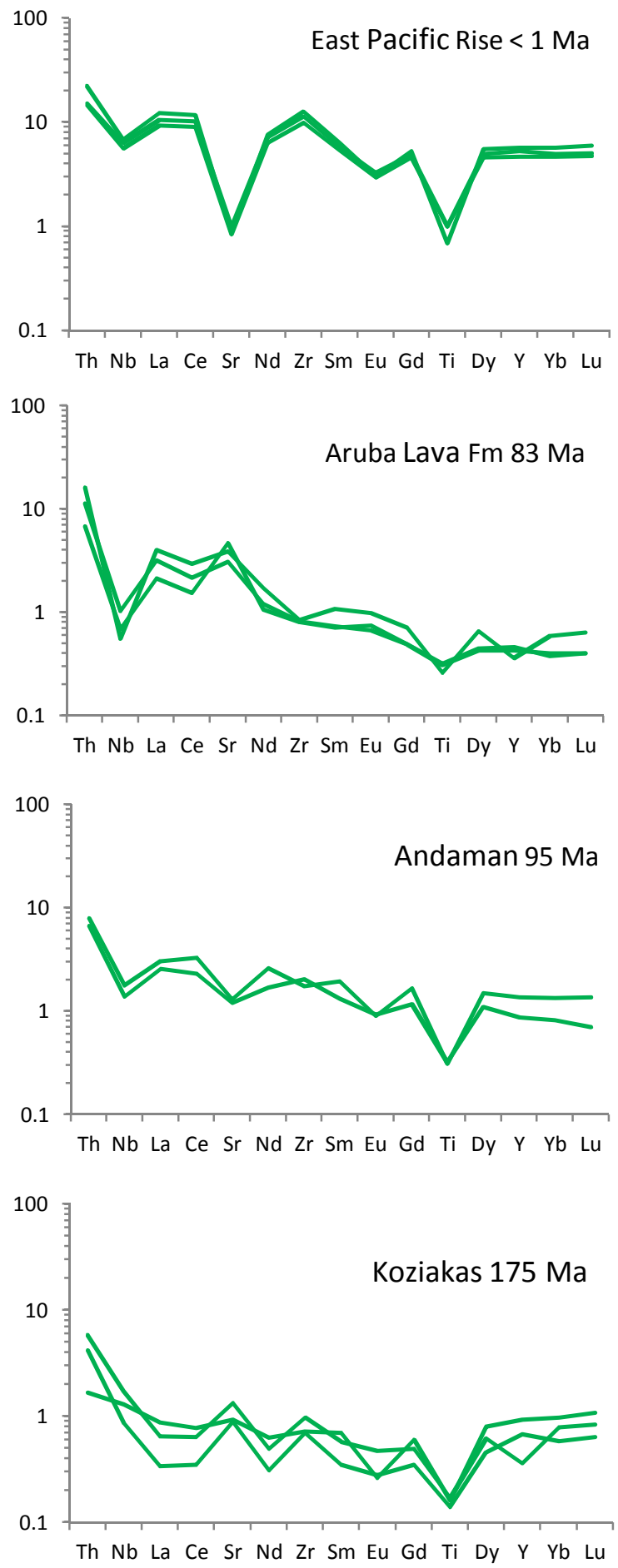


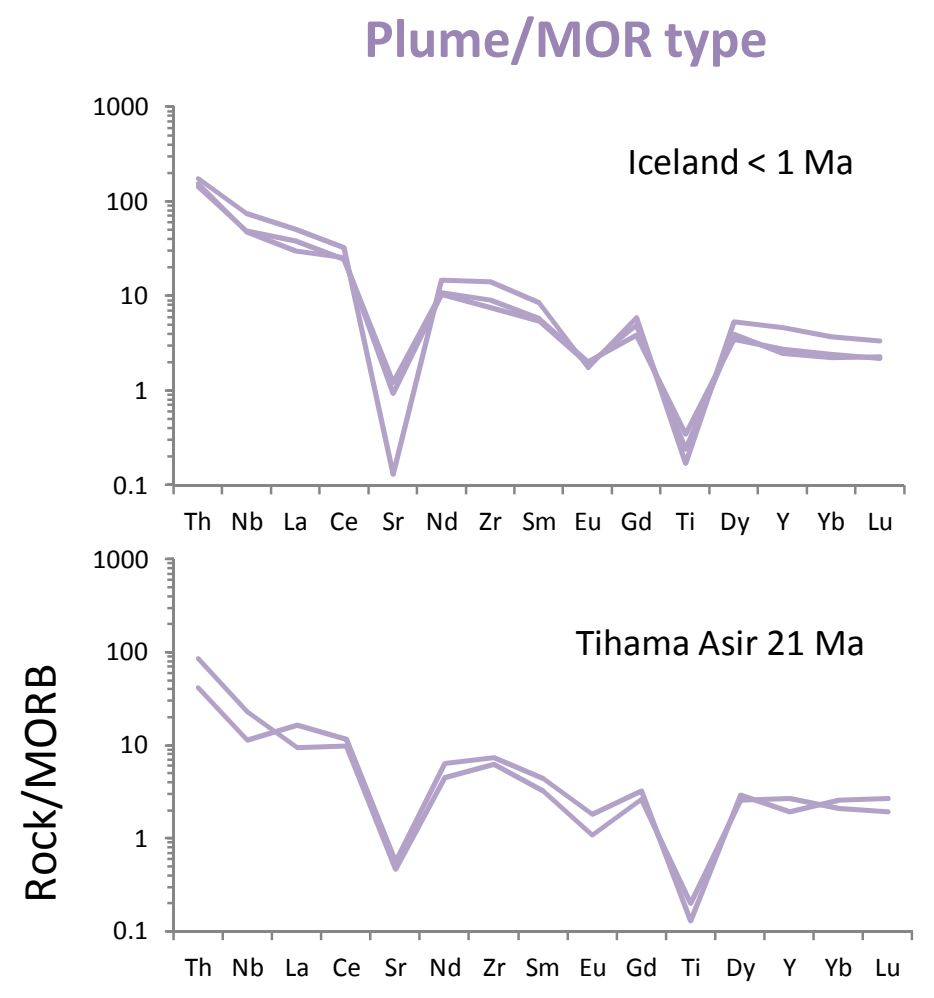

Figure 17.
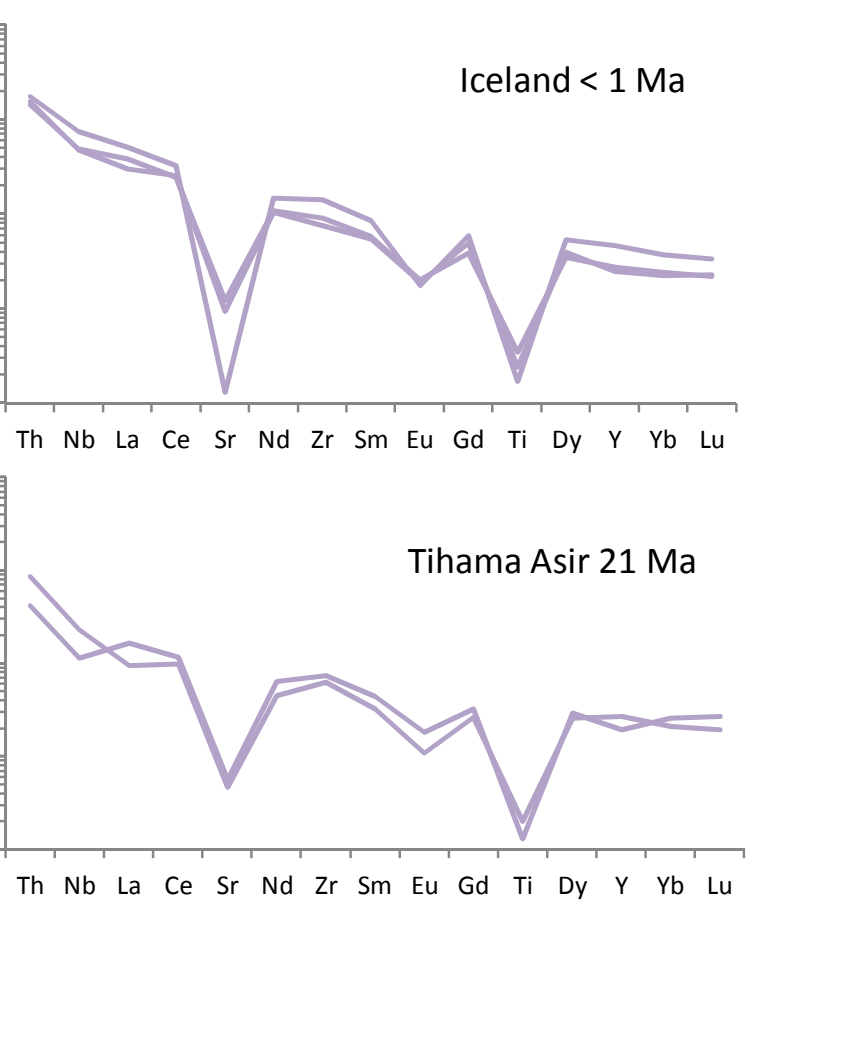


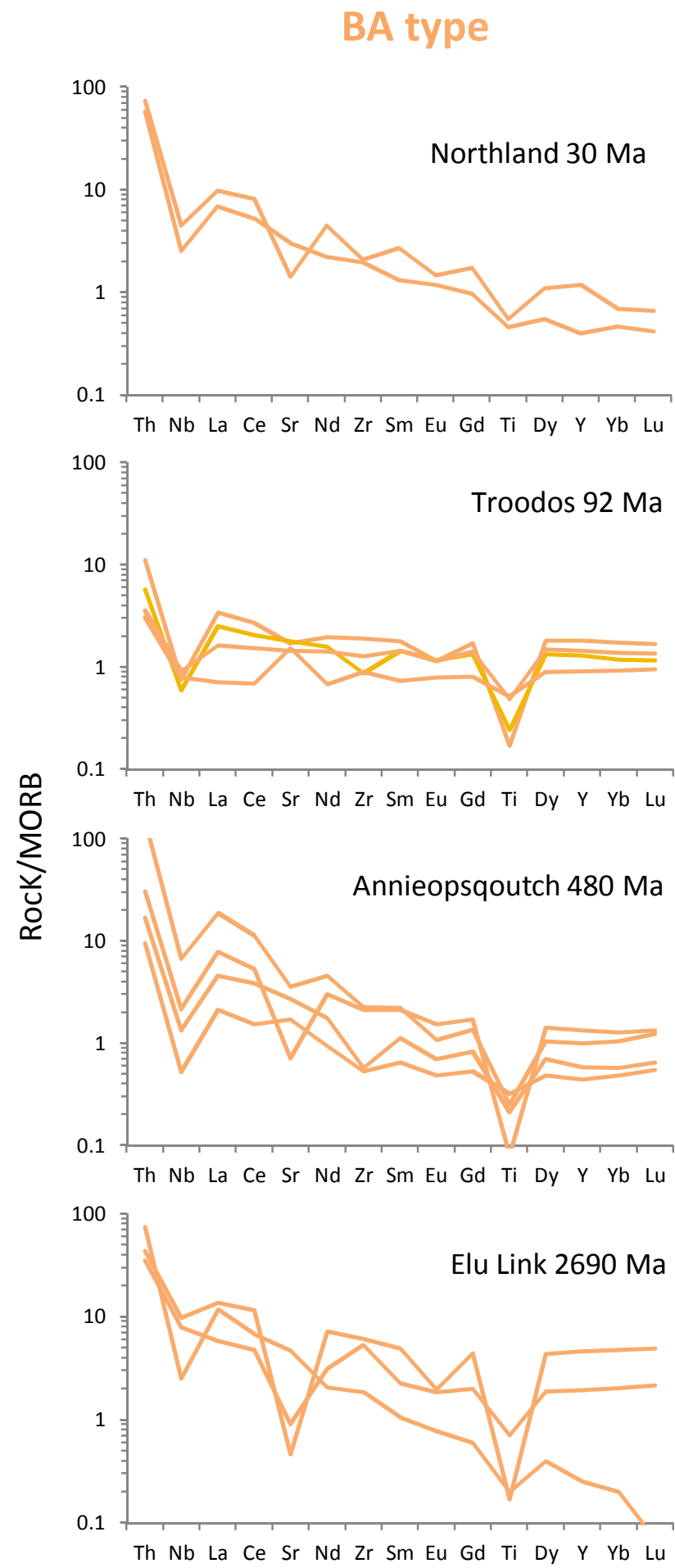

\section{BA - FA type}
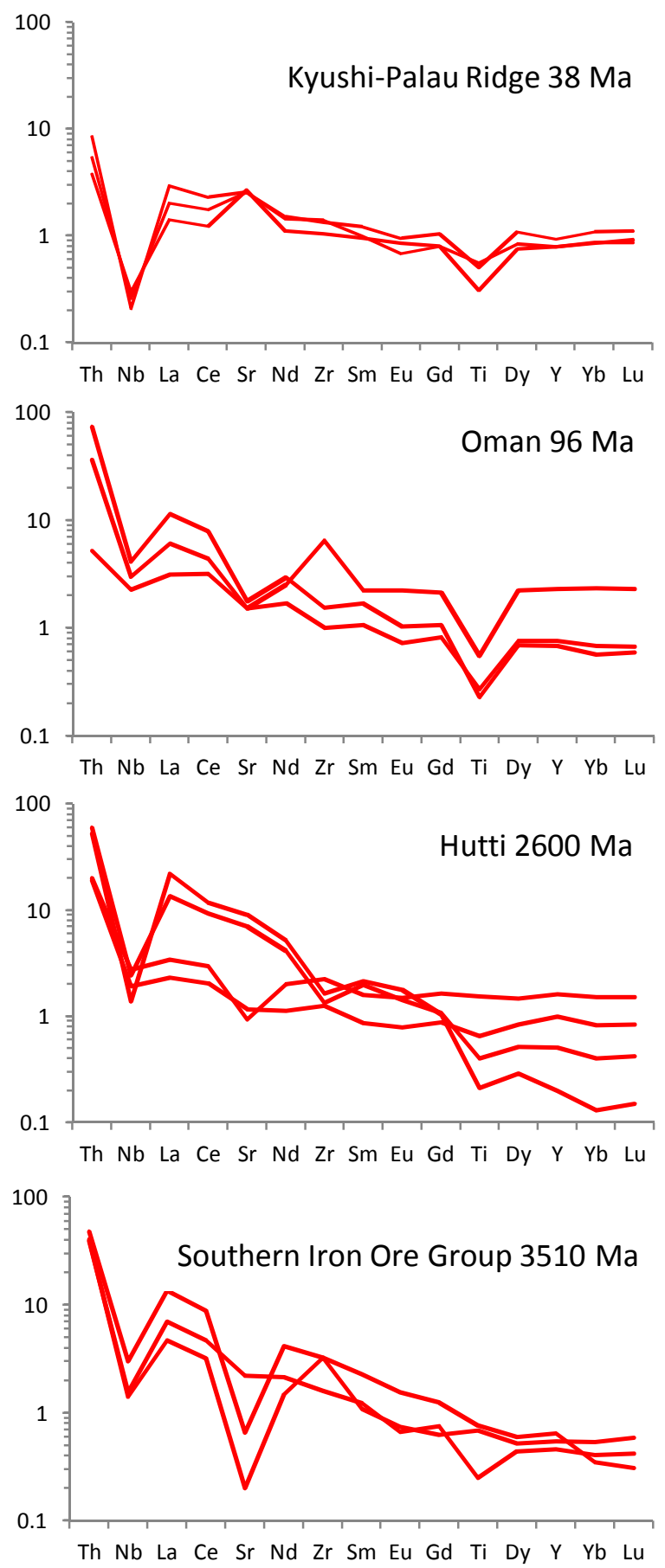


\section{FA type}

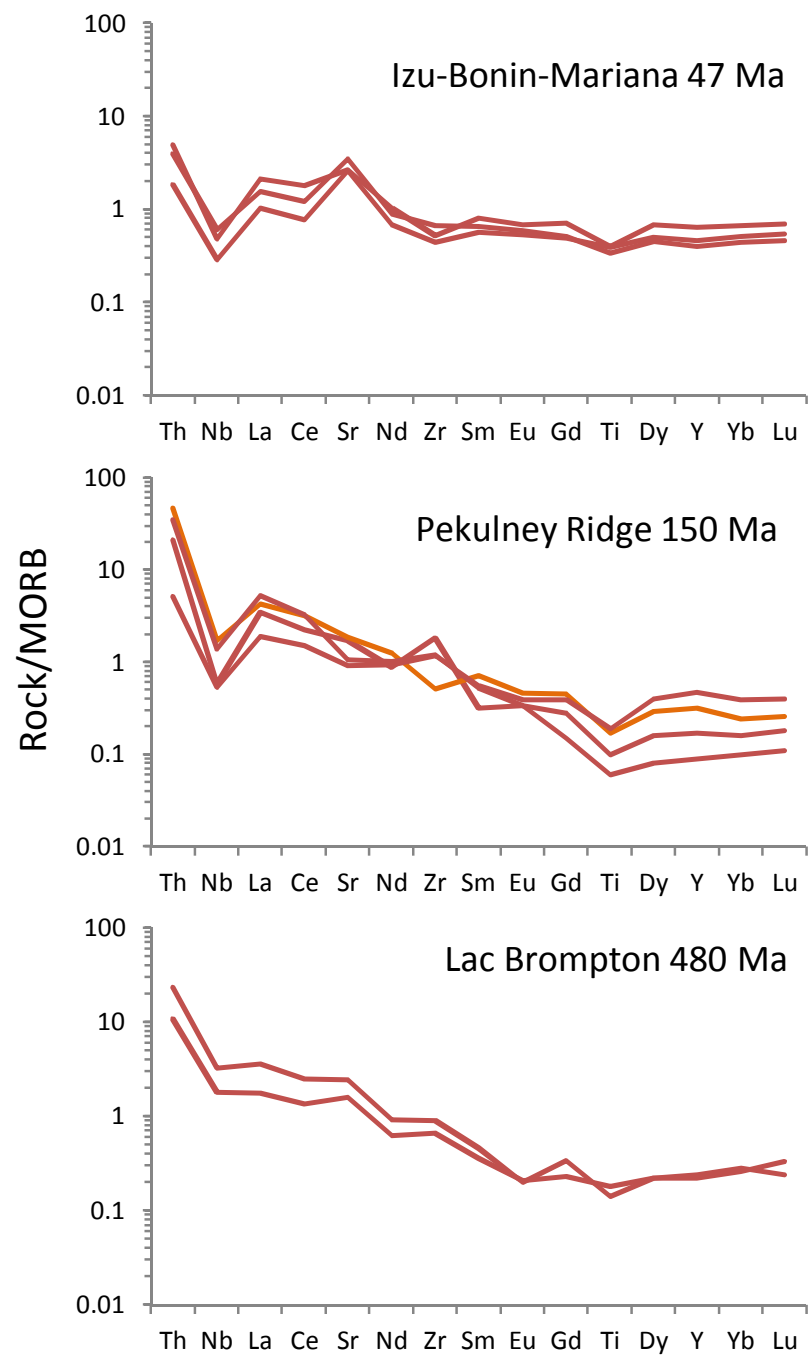

VA type
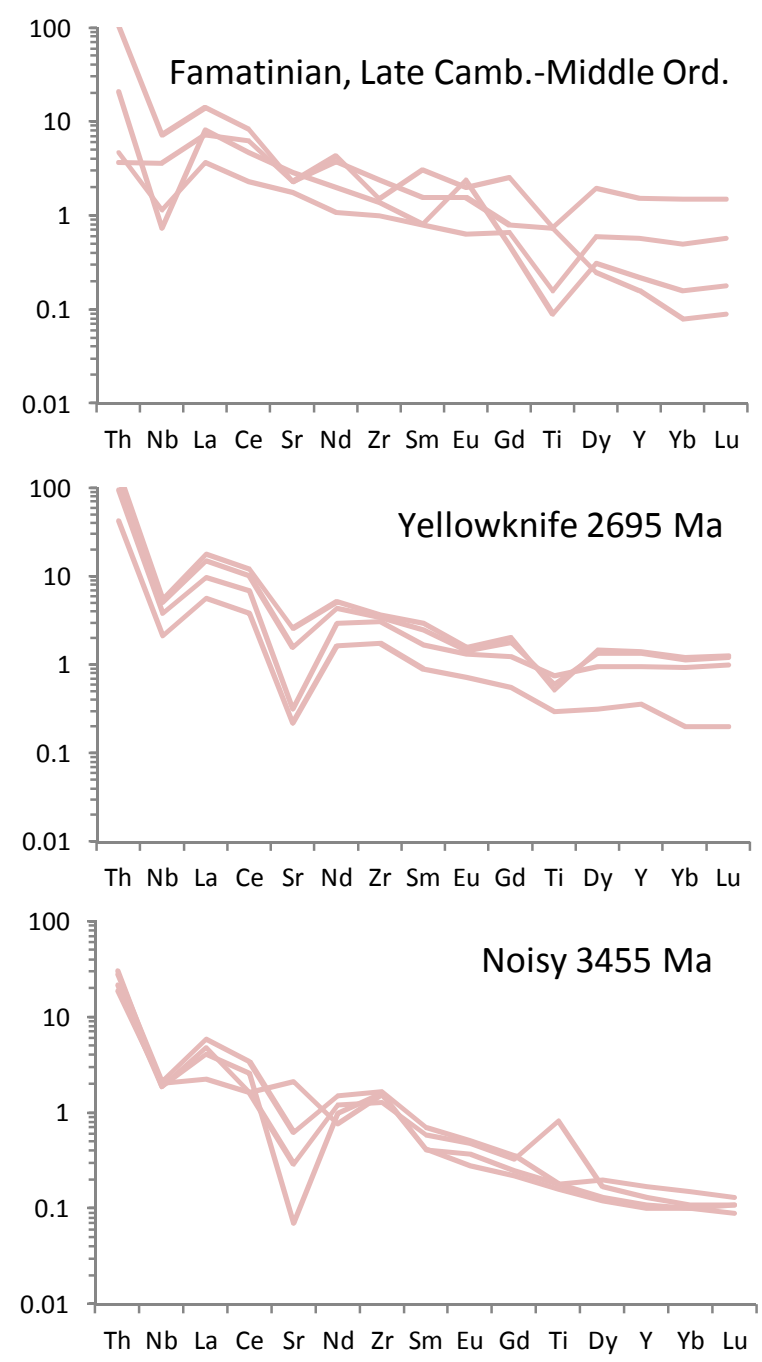


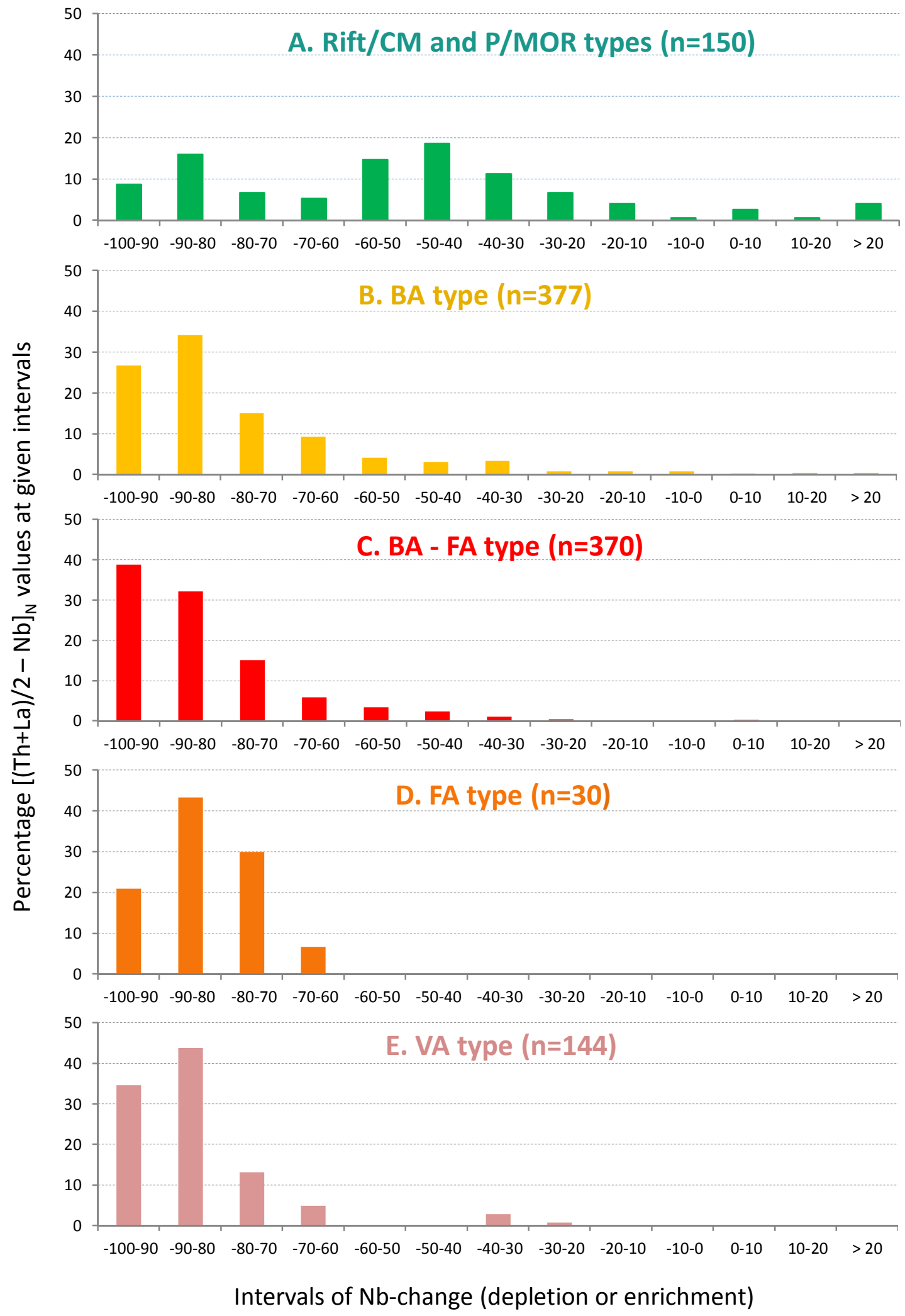




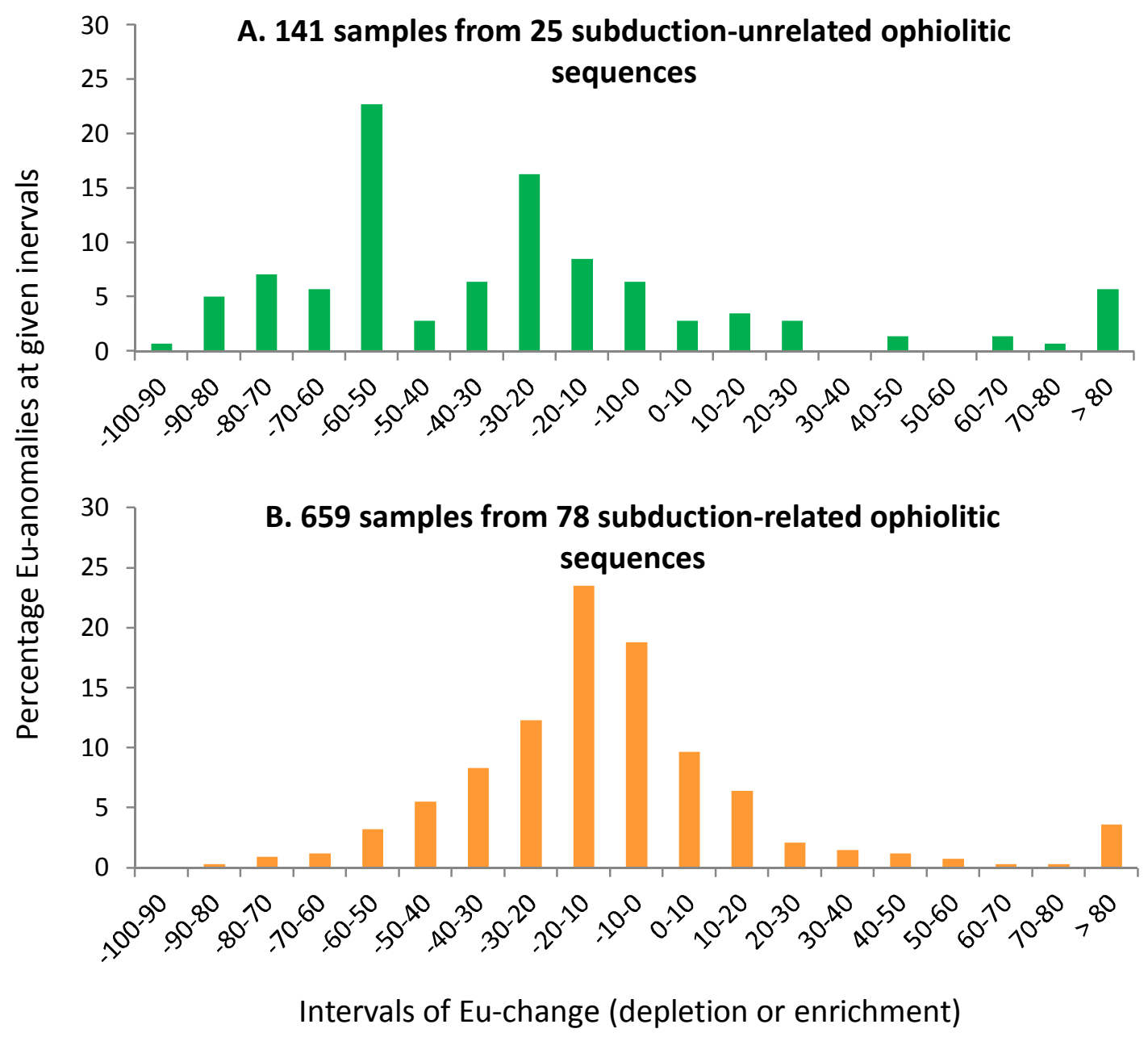




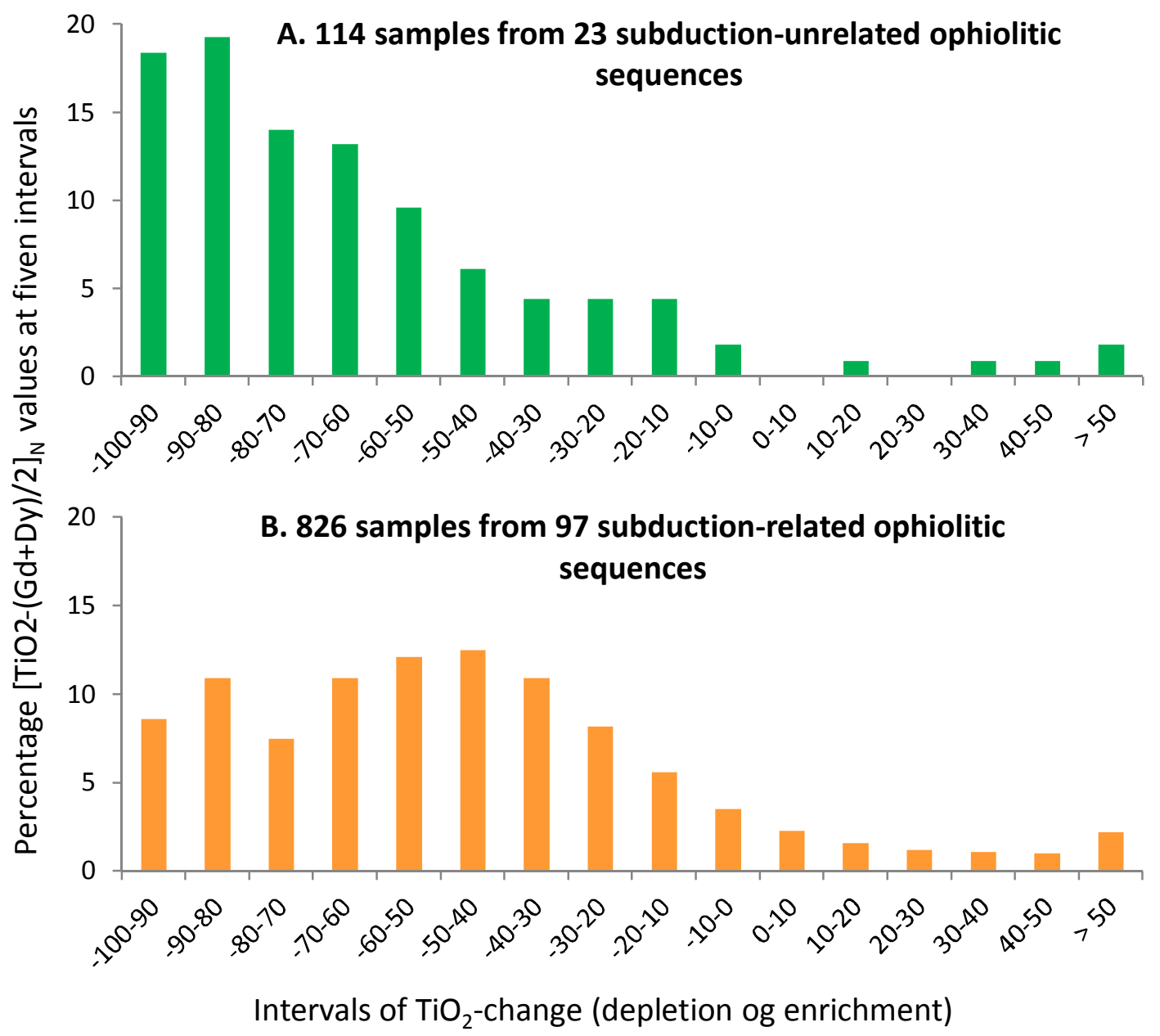



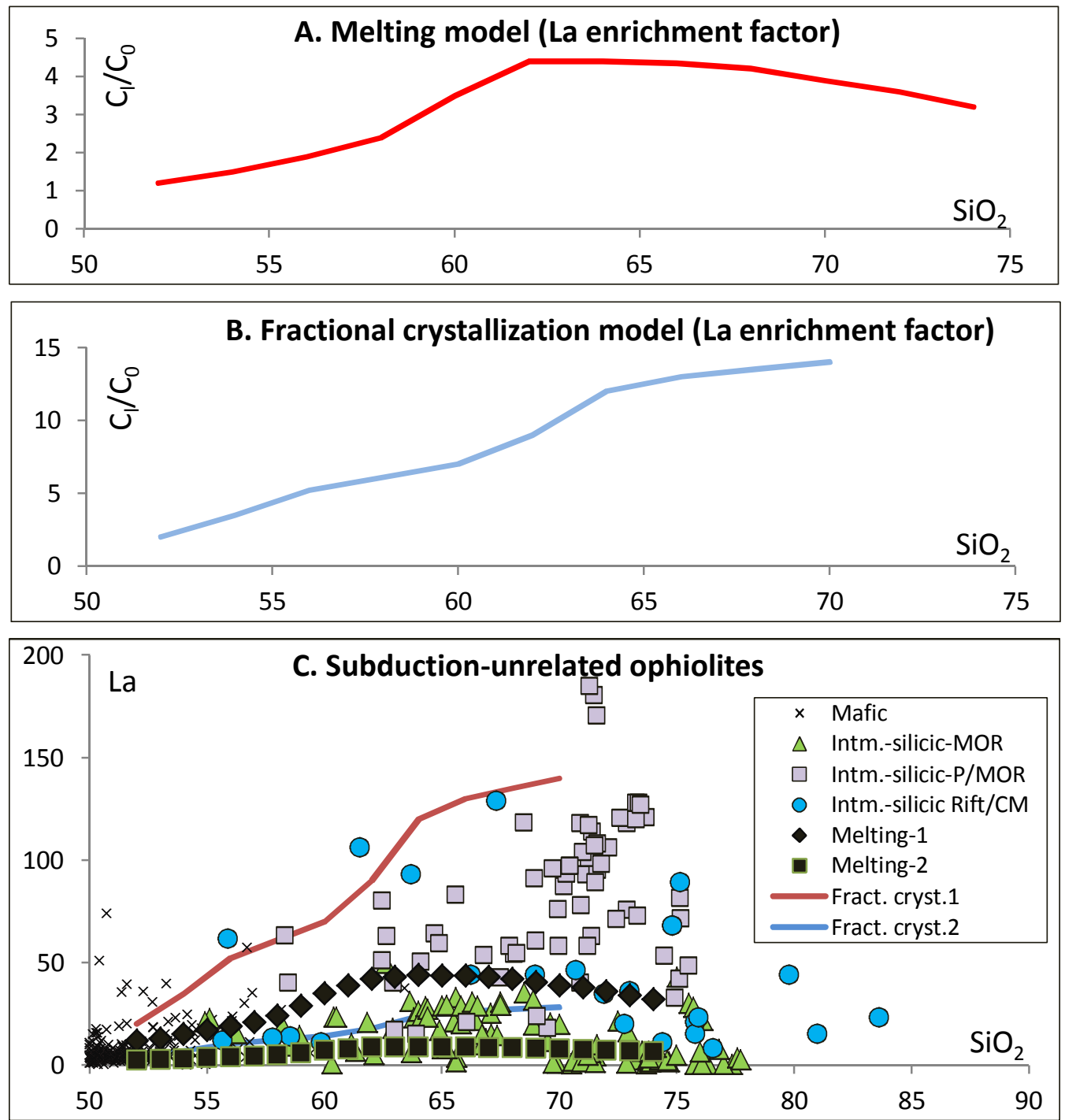

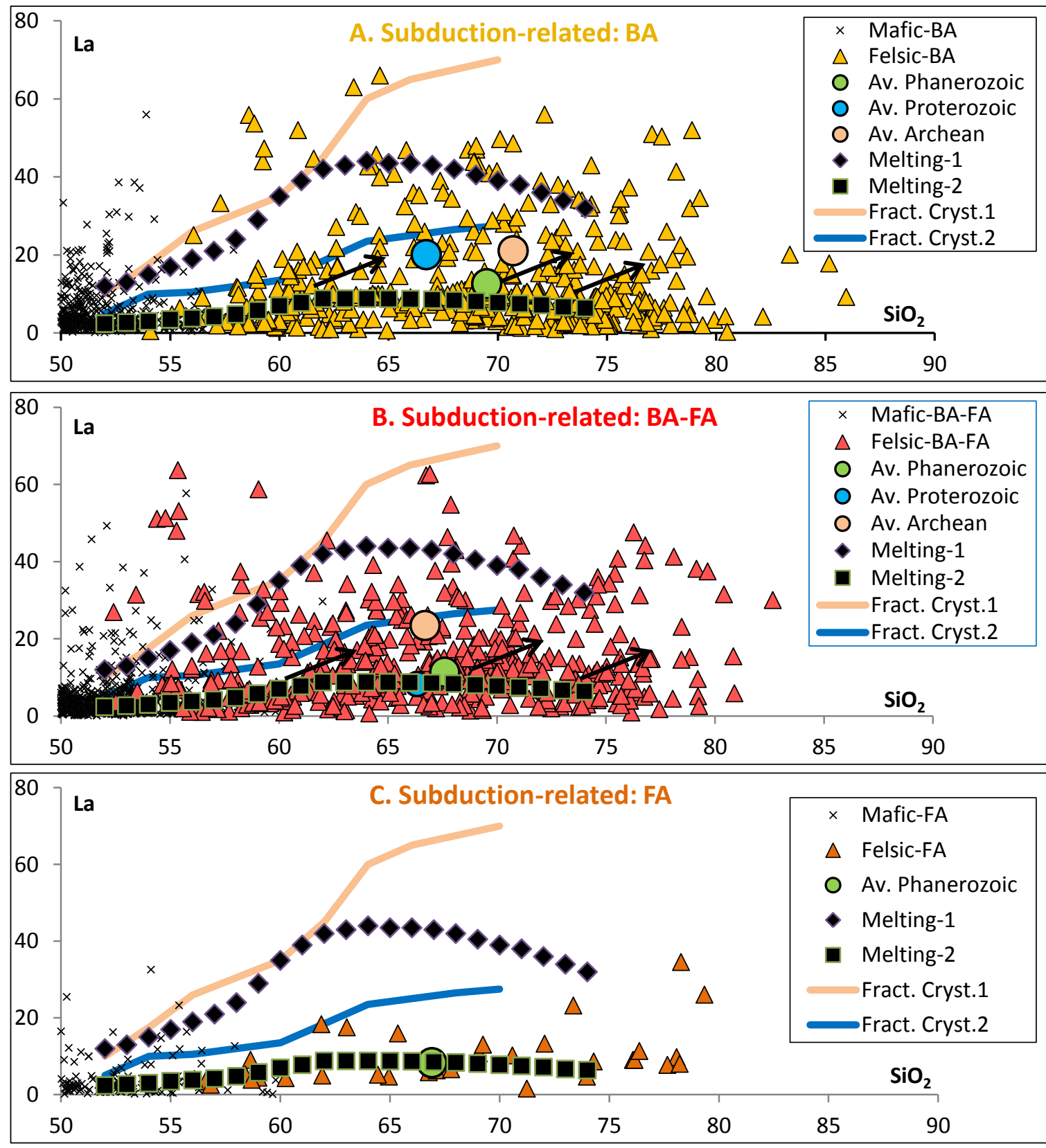

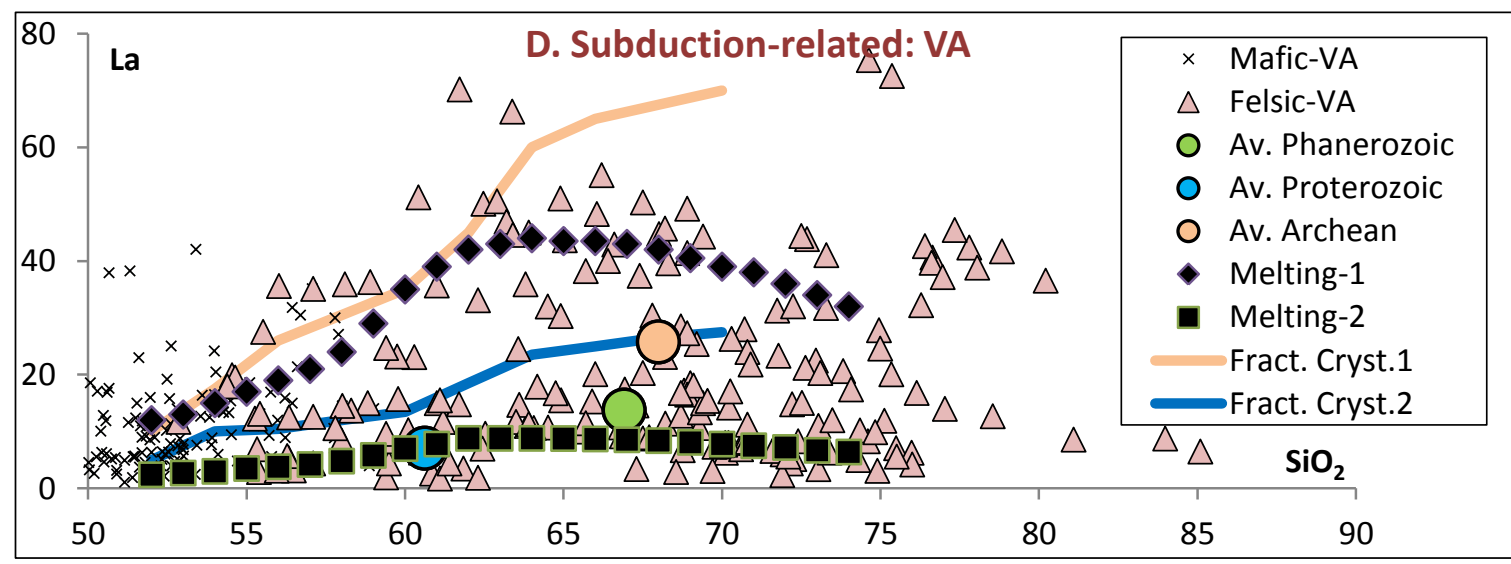



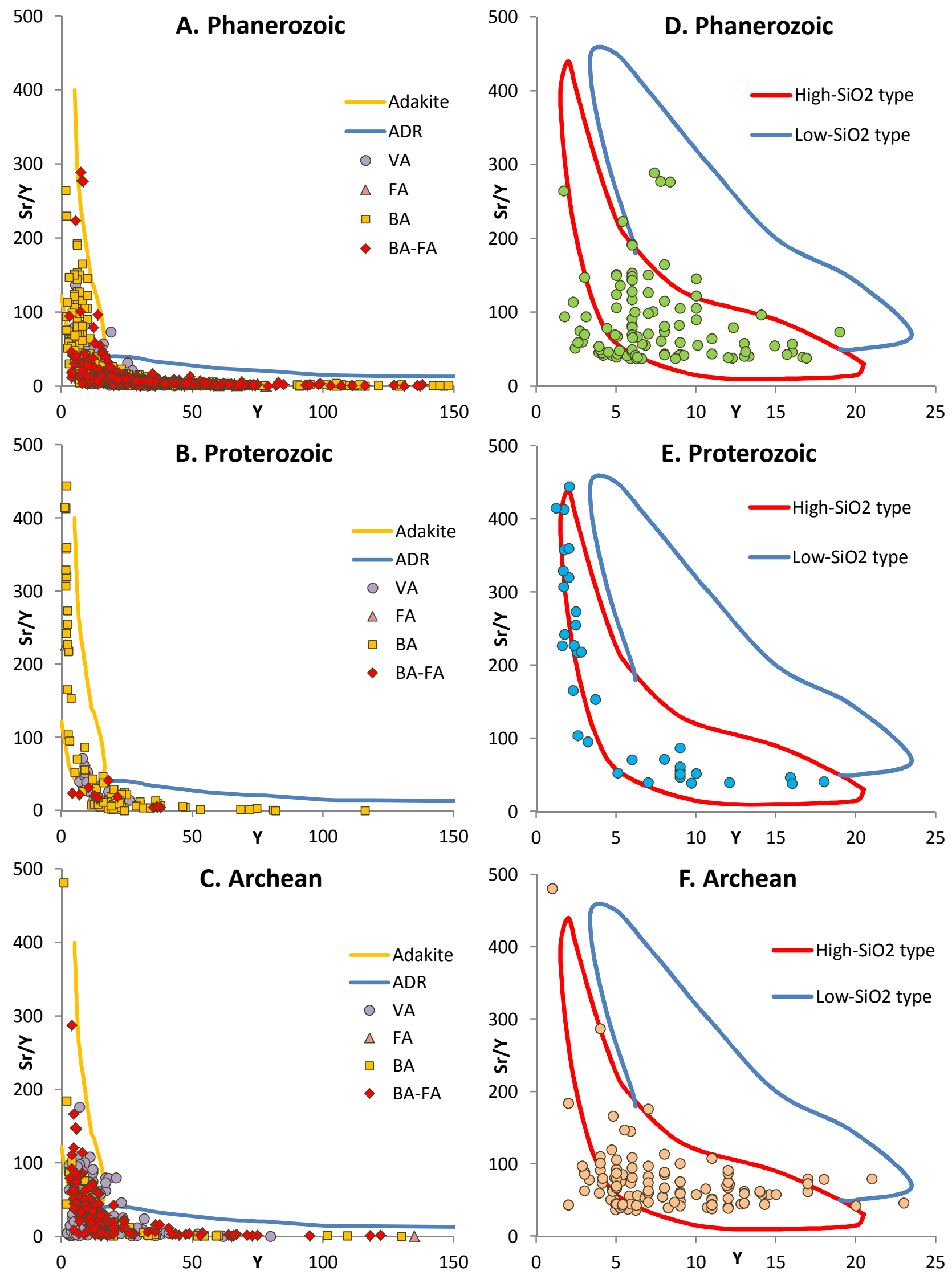
Shallow subduction proxy
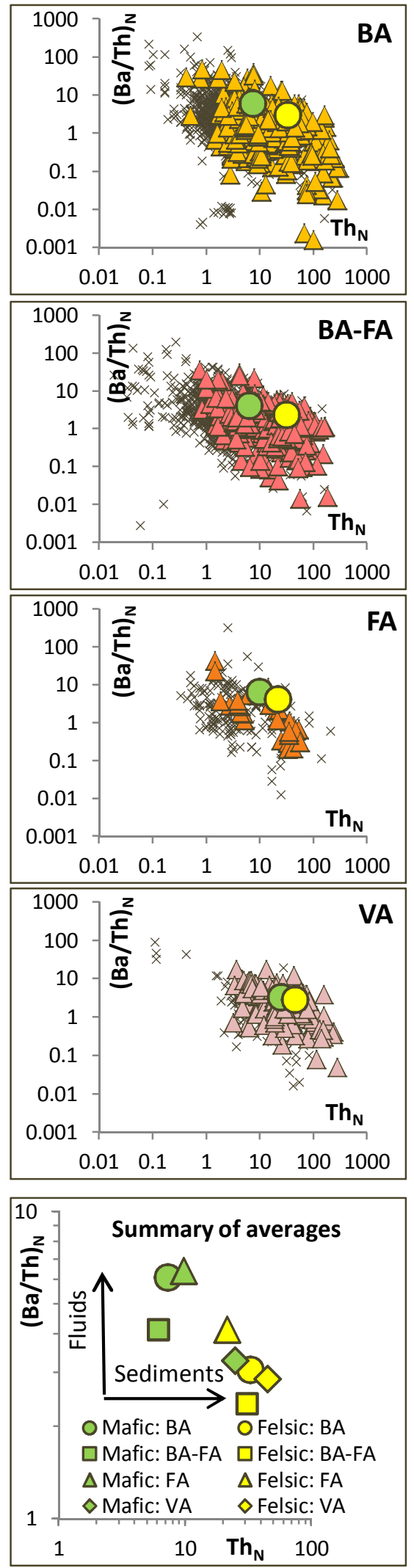

Deep subduction proxy
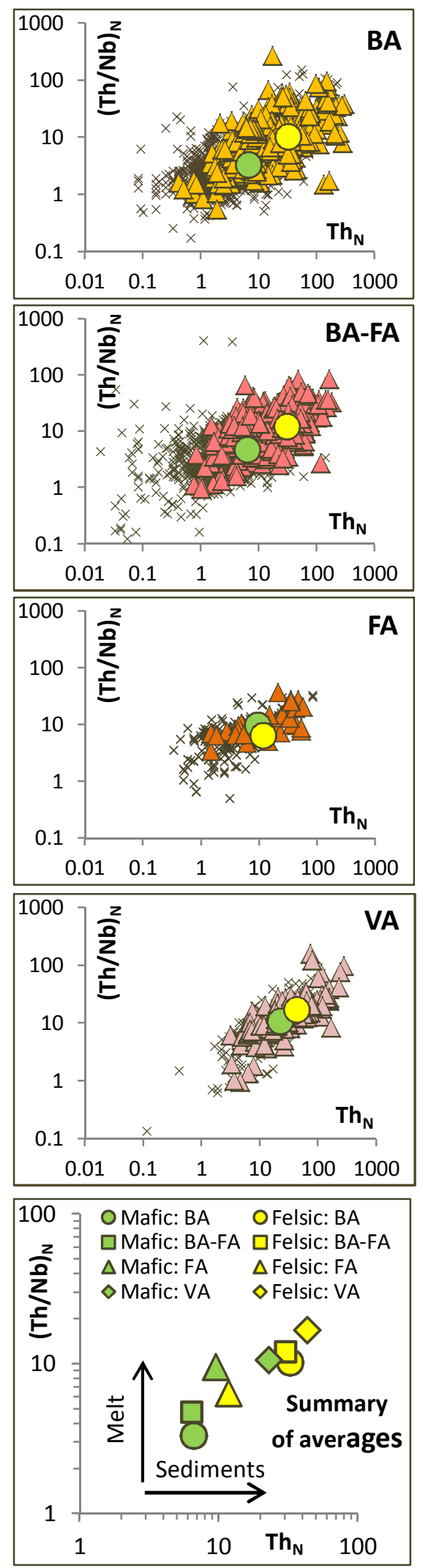

Total subduction proxy
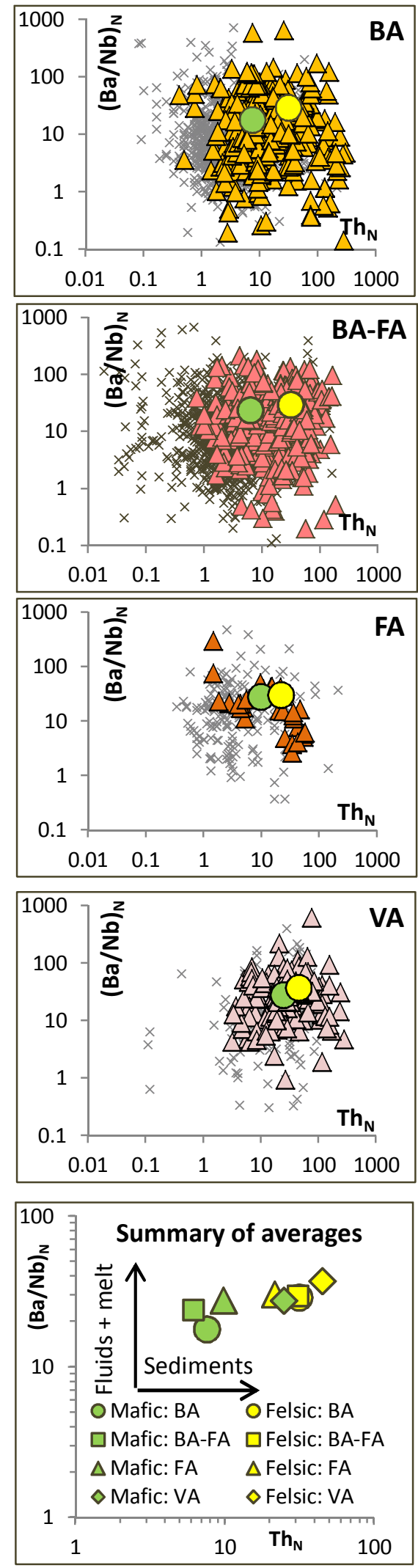

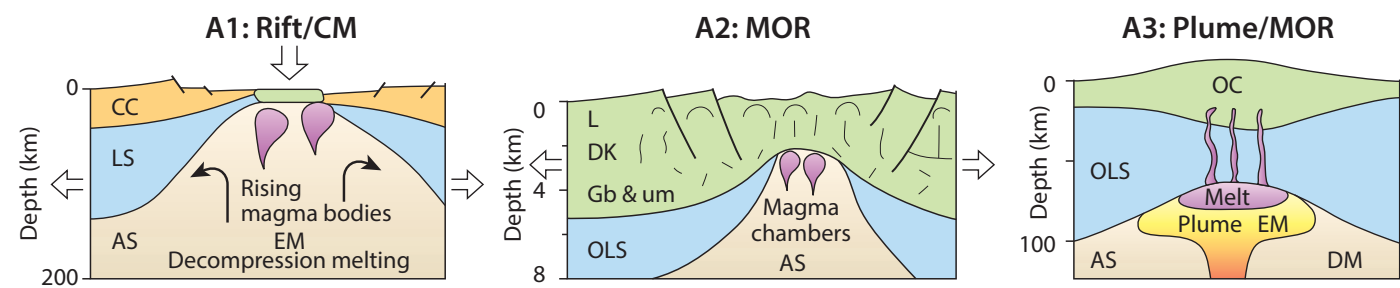

\section{B: Environment of subduction-related ophiolite types}

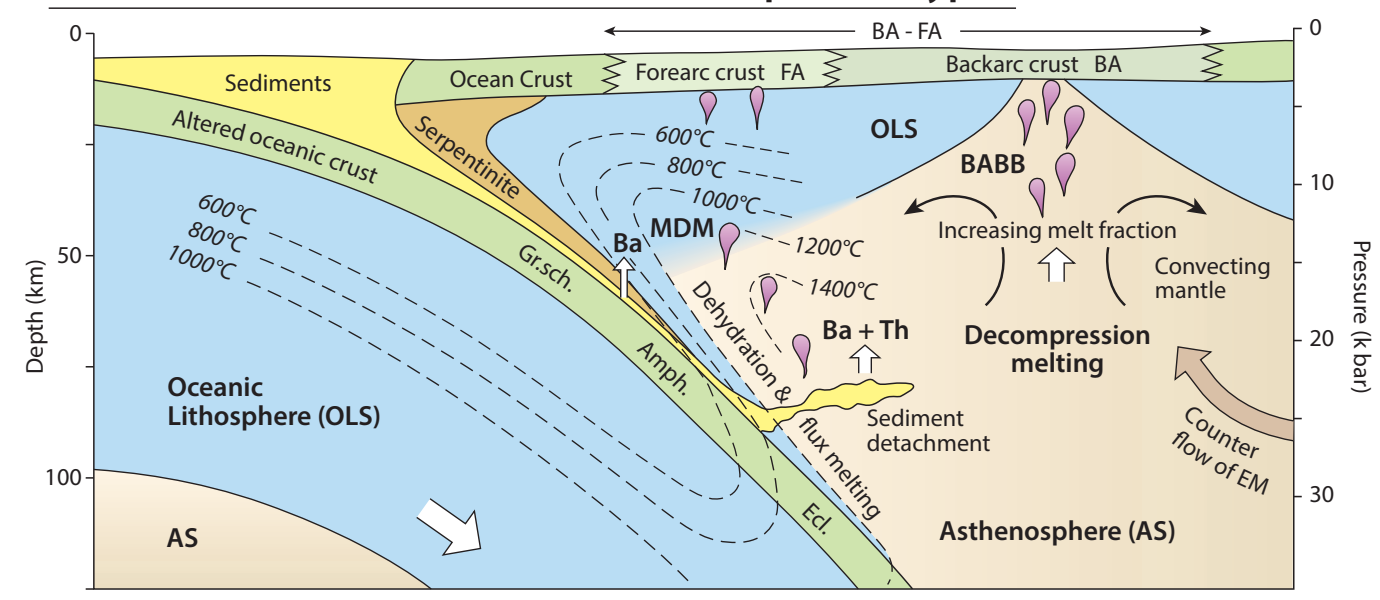

\section{C: Summary and models of intm.-silicic magma generation}
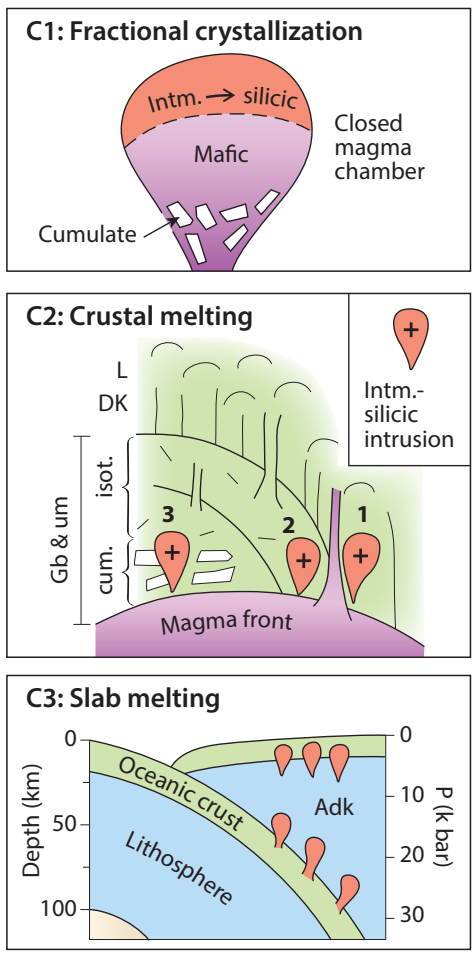
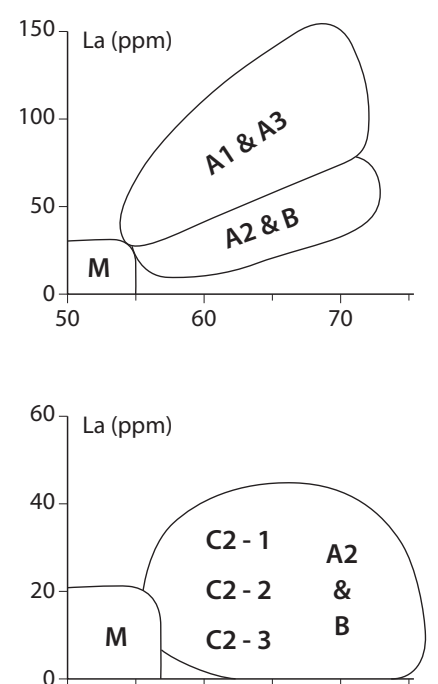

VA
$B A, F A$
$B A-F A$

$\begin{array}{lll}10 & 75 & 15\end{array}$ $45 \quad 40 \quad 15$

Estimated proportion (\%) of processes C1 - C3

Rift/CM

C1 $\mathrm{C2}$ C3

MOR

$5 \quad 95$

Plume/MOR $\quad 85 \quad 15$ 15

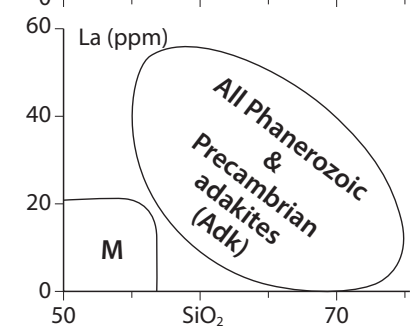

